

\section{Vegas de Antequera y Archidona}

Esta sección ha sido elaborada,

además de por los firmantes, gracias

a la colaboración de Silvia Fernández

Cacho, Valle Muñoz Cruz, Lorena Ortiz

Lozano, David Villalón Torres, Isabel

Durán Salado, Gema Carrera Díaz,

Plácido González Martínez y Marta

Santofimia Albiñana

Nos acercamos en esta ocasión a la vega de Antequera y Archidona, un territorio históricamente marcado por sus características geográficas que lo dotan de carácter fronterizo, con condición de nodo paisajístico y de intersección entre las principales vías de comunicación entre la alta y baja Andalucía. La sección repasa algunos de los elementos más destacados de su rico patrimonio arqueológico, como el Conjunto Arqueológico Dólmenes de Antequera, y otros menos conocidos, como es el caso de los eremitorios rupestres presentes en la zona y la ciudad romana de Singilia Barba. Pero no es el único patrimonio representado. El territorio que hoy proponemos conserva también ejemplos de edificios singulares de la modernidad arquitectónica, como el Teatro-Cine Torcal de Antequera, unido a la potencia de sus formas paisajísticas, con El Torcal y la Laguna Fuente de Piedra como exponentes principales, y de sus manifestaciones y rituales festivos, como correr la vega de la Semana Santa antequerana.

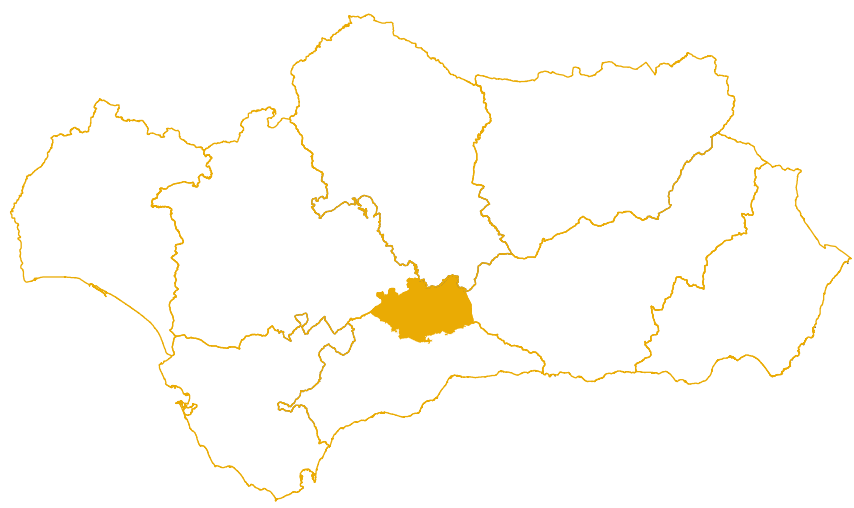




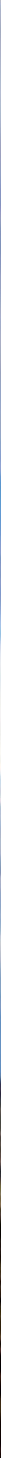

La Peña de los Enamorados sobre la vega de Antequera. Foto: José Manuel Blanco. Fuente: Conjunto Arqueológico Dólmenes de Antequera 


\section{Vega de Antequera y Archidona}

José Ramón Menéndez de Luarca Navia Osorio, arquitecto-urbanista
La Peña de los Enamorados, uno de los hitos más singulares del paisaje andaluz, domina la fértil vega de Antequera y Archidona, dos notables centros históricos que encuentran en la Peña su nexo de unión y, a la vez, la frontera de una tan secular como cordial rivalidad.

Los tres elementos mencionados: la Peña, como representante de un conjunto de elevaciones montañosas presididas por la espectacular formación caliza del Torcal, la planicie de la vega y los asentamientos urbanos, dotados de un rico patrimonio histórico, configuran un paisaje excepcional, tanto por el atractivo de los rasgos que lo constituyen, como por su centralidad en la estructura territorial andaluza.

Al papel de centralidad que la vega ha asumido como nudo de intersección entre las principales vías de comunicación de la región, se superpone la condición fronteriza, una condición mantenida desde sus orígenes. En efecto, el nítido contraste entre la planicie de la vega y las formaciones montañosas que la encierran se generó geológicamente por el choque entre las placas europea y africana. Dentro de las vicisitudes de ese enfrentamiento entre continentes la conexión entre las masas de agua del Mediterráneo y el Atlántico experimentó diversas alternativas hasta alcanzar el paso actual entre las columnas de Hércules que flanquean el estrecho de Gibraltar. En un cierto momento, la comunicación se establecía por un canal dispuesto al norte del cordal subbético. En el proceso orogénico posterior ese pasillo marino sufrió un alzamiento y la continuidad del corredor se fragmentó en un rosario de mares interiores que se sucedian desde la Bahía de Cádiz al oeste, hasta la vega de Murcia y Cartagena pasando por las de Antequera, Granada y Guadix. Una secuencia de espacios fértiles que siguen conformando una vía natural de comunicación, ahora terrestre, entre los dos mares.

Tras un largo proceso erosivo, el mar interior que conformaba la hoy vega de Antequera y Archidona consiguió abrirse paso a través de la muralla caliza de serranía subbética por la estrecha hendidura del desfiladero de El Chorro. Lo abrupto y especta- cular del tajo lo hizo aparecer como una obra titánica que se llegó a relacionar con el mito de Hércules. Como restos del antiguo mar aún permanece una serie de lagunas endorreicas, cuyo ejemplo más notable, la Fuente de Piedra, sigue ofreciendo un magnífico paisaje lacustre y una reserva de salinas que muestran su origen marino.

Los límites del antiguo lago muestran una fuerte disimetria, mientras el límite meridional se configura por una abrupta alineación de elevaciones presididas por la mole del Torcal; hacia el norte se cierra por dos brazos montañosos que se aproximan en sus extremidades: las sierras de Los Caballos y de Arcas; entre ambas, el cerro de La Camorra define dos amplias aperturas hacia el suave paisaje de campiña del valle del Guadalquivir.

Lo peculiar de ese cinturón montañoso es que su carácter abrupto contrasta con su escasa profundidad, de forma que entre sus picos más altos deja una serie de pasos de relativo fácil tránsito desde las ensenadas de Málaga y Vélez Málaga en el Mediterráneo hacia el interior de la península. La vega goza así de una accesibilidad privilegiada frente a la impenetrabilidad de los profundos macizos montañosos que la flanquean por oriente y occidente: la Serranía de Ronda y el altiplano de Loja.

El conjunto de rasgos naturales descritos conducen a la configuración de un paisaje tan privilegiado como singular. Desde el punto de vista de la accesibilidad, en él se produce el entrecruzamiento de corredores naturales de largo recorrido: de este a oeste y de norte a sur. Por lo que se refiere a la fertilidad, la planicie de la vega ofrece suelos profundos y bien irrigados. La coexistencia de la llanura con el cinturón montañoso que la protege ofrece la posibilidad de frescos pastos de verano que refuerzan su potencial ganadero. También desde el punto de vista minero, la abundancia de sal y los diversos tipos de rocas refuerzan las favorables condiciones del lugar. Por último, queda referirse al fuerte contraste entre la amplia llanura de la vega y la verticalidad de los riscos que la cierran que lo singulariza frente a los territorios vecinos. Es un paisaje destacado por la claridad, por la nítida distinción entre 
Al papel de centralidad

que la vega ha asumido

como nudo de intersección

entre las principales vías de

comunicación de la región,

se superpone la condición

fronteriza, una condición

mantenida desde sus

orígenes

figura y fondo. No es de extrañar que tan favorables condiciones naturales hayan propiciado a lo largo de la historia la continua aparición de hechos culturales de primer orden hasta llegar a conformar un paisaje de extraordinaria complejidad.

Desde el inicio la riqueza vegetal y faunística atrajo a las primitivas sociedades de cazadores y recolectores, para quienes los collados de entrada al valle constituian pasos obligados donde sorprender a sus presas. En uno de esos lugares, en el margen del puerto de Málaga, se creó, en la Cueva de Ardales, el santuario de pintura paleolítica más rico y extenso del sur de la península.

La paulatina introducción de la ganaderia y la agricultura que caracteriza a las civilizaciones del neolítico y el calcolítico se corresponde con unos nuevos modos culturales. La marcación del paisaje que suponemos se propone realizar el arte rupestre del neolítico-calcolítico encuentra un soporte privilegiado en la citada nitidez del peculiar paisaje de la vega de Antequera y Archidona. En efecto, ni la monótona sucesión de colinas redondeadas de la cuenca del Genil o de la campiña del Guadalquivir que confinan la vega por el norte, ni el intrincado paisaje erosivo de los montes de Málaga por el sur, presentan las condiciones adecuadas para la señalización de hitos paisajísticos diferenciados y de amplia visibilidad.

Frente a la marcación de hitos naturales preexistentes, que caracteriza al arte rupestre, las arquitecturas megalíticas plantean una estrategia alternativa, la de creación "ex novo" de un hito, generalmente en zonas de paisaje menos prominentes. La monumentalidad sin parangón de los monumentos antequeranos de Menga, Viera y El Romeral es la mejor muestra del excepcional desarrollo inducido por la explotación de los recursos del lugar.

Con la implantación de la cultura del bronce, una sociedad más bélica y jerarquizada tiende a ocupar lugares prominentes, de más fácil defensa, lo que supone la elección de emplazamientos escarpados que mantendrán ese uso en la historia subsiguiente: Castillejos de Teba, Ardales, Castillón de Singilia, Peña de los Enamorados, Aratispi.
La llegada de los pueblos del mediterráneo oriental, fundamentalmente fenicios $y$, en menor medida, griegos, a las ensenadas costeras, se acompaña con la introducción de nuevos cultivos como el olivo y la vid que, junto al trigo, constituyen la tríada mediterránea que dominará el paisaje agrario posterior. Los hábitos comerciales de los nuevos colonizadores dan lugar a activas relaciones de intercambio con los pueblos del interior, con lo que se contribuye a la paulatina constitución de una sociedad más urbanizada. La inusitada dimensión de la muralla ibérica que circunda la hoya de Archidona es buena muestra de la riqueza de sus constructores. Tales circunstancias implican un fortalecimiento de las rutas de largo recorrido, tanto las que unen las Ilanuras agricolas interiores con las ensenadas portuarias de Vélez Málaga y Málaga como las que discurren por el corredor este-oeste.

La dominación romana supuso una fuerte intensificación de la explotación del territorio promovido por la creciente demanda de la metrópoli. Sobre la base de la excepcional riqueza agraria, salinera y minera de la comarca se crea una densa ocupación de las áreas más fértiles mediante una dispersión de villae en las que el olivo se configura como absoluto protagonista del flujo exportador. Una intensificación agraria lograda mediante la generalización de los sistemas de regadío que propicia el desarrollo de prósperas ciudades, como Singilia y Anticaria. Prueba del nivel alcanzado son las exquisitas obras escultóricas alli aparecidas, como el famoso Efebo de Antequera.

La irrupción de los pueblos germánicos supuso el establecimiento de una condición fronteriza a lo largo del cordal subbético, que separaba el dominio mediterráneo bizantino de las tierras visigóticas del interior. Una condición fronteriza que se mantendría, salvo pequeños intervalos, en el milenio posterior.

Con la dominación islámica la comarca antequerana forma parte de la cora (demarcación provincial) de Raya con un centro principal en Archidona que disputa a Málaga la capitalidad. El dominio del territorio se distribuye entre los nuevos habitantes, ocupando las estirpes árabes la llanura y los bereberes norteafricanos las áreas montañosas.

Si en los periodos precedentes la característica de la zona como lugar de paso y cruce de caminos había sido enfatizada como promotora de intercambios, ahora se va a configurar como un persistente espacio de frontera, acompañado de continuos conflictos bélicos, traducidos en un acelerado proceso de fortificación del territorio.

El largo conflicto protagonizado por Umar Ben Hafsun a caballo de los siglos IX y X enfrenta la población mozárabe y muladi de la comarca con el poder central cordobés. Como consecuencia, ambos bandos contienden en la elevación de grandes alcázares fortificados en las antiguas ciudades, como Antequera y Archidona, Ardales, Teba y Cañete, pero también en otros puntos prominentes con especiales características defensivas, entre los que destaca Bobastro. El conjunto formado por las iglesias rupestres 

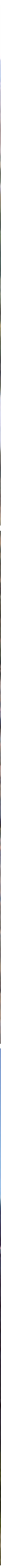

1. Desfiladero de El Chorro.

Foto: José Ramón Menéndez de Luarca

3. Dolmen de Menga.

Foto: Javier Pérez González. Fuente: Conjunto Arqueológico Dólmenes de Antequera

5. La vega de Antequera desde lo alto de la Peña de los Enamorados.

Foło: Aurora Villalobos. Fuente: Conjunto Arqueológico Dólmenes de Antequera

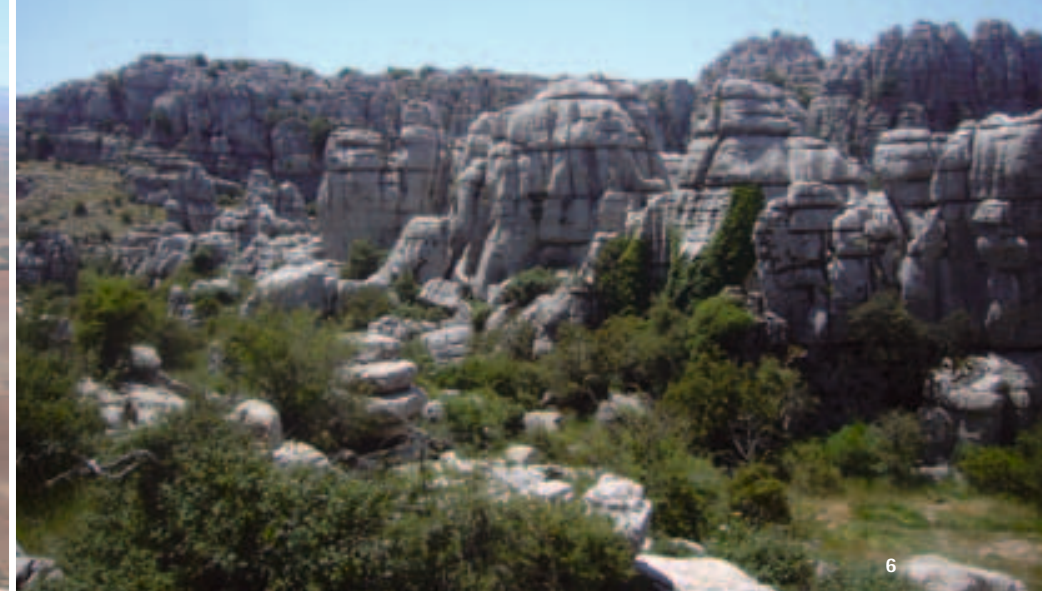

2. Laguna de Fuente de Piedra

Foto: José Ramón Menéndez de Luarca

4. Vista de Archidona con la plaza octogonal.

Foto: José Ramón Menéndez de Luarca

6. Vista del Torcal.

Foto: José Ramón Menéndez de Luarca 


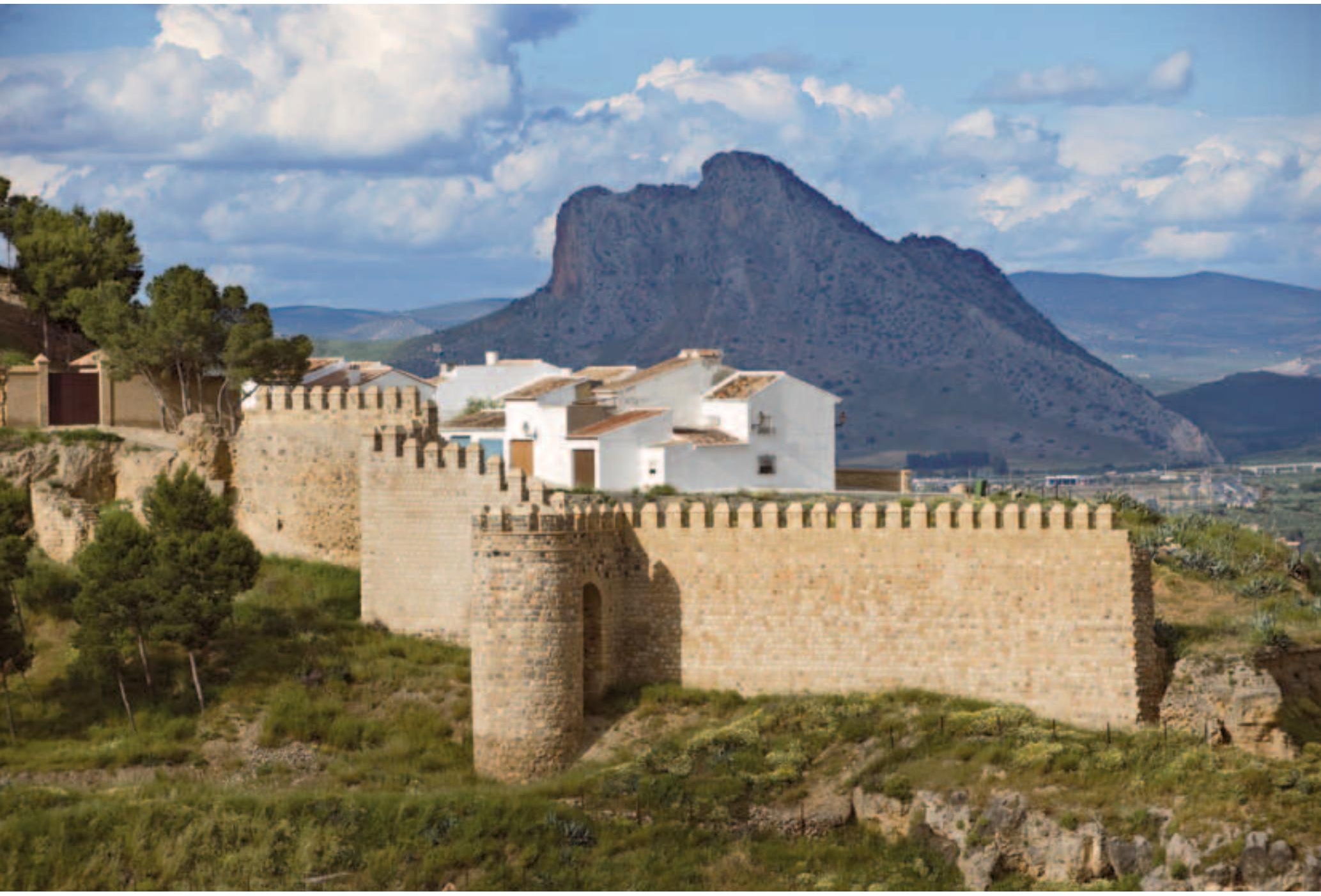

Muralla de la Alcazaba de Antequera. Foto: Juan Carlos Cazalla, IAPH

y las obras defensivas en tan espectacular risco conforma uno de los paisajes más singulares del ámbito.

El avance de la reconquista en el XIII y el consiguiente aislamiento del reino granadino endurecen las condiciones bélicas de frontera. Se asiste a un proceso generalizado de encastillamiento mediante la erección de un sistema de torres vigía o almenaras, hachos en la versión romance, que ocupan algunos riscos inaccesibles de gran proyección paisajística, como ocurre con las de Aznaraz o Zambra.

En cualquier caso, y a pesar de la constricción bélica, se asiste a una intensificación de los sistemas agrarios de regadio, en las proximidades del ámbito protegido de las ciudades, como ocurre en los ruedos de Antequera y Archidona.

La conquista cristiana fue acompañada en las tierras de Antequera por la expulsión total de la población precedente, lo que supuso una ruptura en las tradiciones que regulaban en el manejo del espacio. Tras la conquista definitiva de Granada se establecen las bases para un súbito florecimiento de la comarca, manifiesto en la proliferación de nuevas villas. Si la situación anterior de las medinas venía condicionada por las necesidades defensivas, ahora las villas nuevas, como la de Campillos, buscan su localización en las Ilanuras más fértiles. En general, se trata de poblaciones planificadas según una malla rectangular, de gran interés, por constituir un precedente del modelo que se generalizará en la sucesiva colonización americana.

Otro rasgo significativo para la reorganización territorial fue la especialización ganadera de los nuevos conquistadores. Para facilitar el movimiento de los rebaños se dispuso una densa malla viaria de cañadas, o realengas, de corto y largo recorrido, que ocupan viejas sendas inmemoriales. De este modo, se viene a reforzar el papel central de Antequera, como cruce de rutas y centro comercial. A su vez, el desarrollo de la industria del tejido, asociado a la producción de lana, estimula el crecimiento de la zona. Testigo de tal desarrollo es el inusitado esplendor del barroco en las iglesias, palacios y plazas públicas de Antequera y Archidona.

Tras un periodo de decaimiento, entre 1910 y 1980, el área experimenta un súbito crecimiento a partir de su configuración como nudo de comunicaciones andaluz. El hacer compatible tal dinamismo urbano con una adecuación a las condiciones naturales y a su rica elaboración cultural a lo largo de la historia constituye el reto a afrontar en el futuro. 


\section{Conjunto Arqueológico Dólmenes de Antequera. Un Plan Director para la tutela}

Pensar hoy la intervención sobre un patrimonio milenario supone avivar la interpretación de esta herencia ancestral iluminándola a partir del punto de vista propio de nuestra posición vital. Ello supone responder al reto de la excepcionalidad del valor heredado confrontándolo con la máxima exigencia cultural de nuestros dias. Tal exigencia se plantea desde todos los ámbitos de la cultura contemporánea. Por lo que respecta al conocimiento del pasado, con la intervención de los investigadores e instituciones más avanzadas del mundo científico; por lo que respecta a la tutela de conservación, de mantenimiento de la presencia del monumento, mediante la aplicación de una tecnología de conservación más puesta al dia; $y_{1}$ lo que es más importante, en su proyección futura, mediante la recepción de los valores patrimoniales por la creación artística contemporánea y su difusión en la nueva sociedad de la comunicación.

Para la consecución de dichos objetivos partimos del hecho afortunado de que en la cultura de las grandes piedras esa labor de actualización resulta especialmente fácil y atractiva por cuanto muchos de los temas fundamentales de nuestro paradigma cultural encuentran su fiel reflejo en aquella. Las relaciones hombre-entorno que configuran los procesos de largo alcance en el espacio y en el tiempo, que hoy se reivindican frente a los desastrosos efectos de la imposición sobre el medio del oportunismo y la banalidad, aparecen a nuestra vista expuestos con especial nitidez en los monumentos de las grandes piedras. Un arte que llama la atención sobre los rasgos definitorios de los grandes conjuntos del paisaje y sobre la inserción en el cosmos del lugar.

Pero dentro de estas caracteristicas comunes al fenómeno megalítico la excepcionalidad de valores que concurren en el caso del conjunto de Antequera, quizás el más importante de la Peninsula y uno de los más notorios de Europa, nos abre los ojos sobre la necesaria excepcionalidad del paisaje que los ha generado, la magnifica vega de Antequera presidida por el hito monumental de la Peña de los Enamorados en su centro y la Sierra del Torcal en la lejanía. Por eso la actualización de esos valores implica hacer valer la importancia de esa herencia milenaria frente a la banalidad de los oportunismos del momento. Es precisamente la coherencia en defensa de esos valores la que debe establecer el prestigio de la institución encargada de la tutela.

Consecuentemente el Plan Director ${ }^{1}$, en cuanto plan estratégico, debe aceptar la paradoja de que estrategia y planificación suponen dos actitudes distintas. La estrategia implica una forma de actuar flexible frente a otros interlocutores que defienden intereses en conflicto y cuyo resultado siempre es incierto y, aceptando la metáfora bélica implícita en el término, exige una continua readaptación de las posiciones a las maniobras, no siempre previsibles, de los contendientes.

La planificación supone, por el contrario, el compromiso de realizar en el futuro los objetivos claramente establecidos en la actualidad, tal como se verifica en el ámbito proyectual. Por eso el aspecto de planificación debe prevalecer en los aspectos internos en los que se trata de ordenar la aplicación de los recursos propios en el futuro, mientras la aproximación estratégica es más adecuada al ámbito externo y territorial, donde el sector cultural es un actor entre tantos que ocupan un escenario en el que representan puntos de vista muy diversos y no siempre conciliables. Esa flexibilidad debe estar presente desde el inicio si no se quiere incurrir en propuestas cerradas solo conducentes a la frustración.

A las exigencias que la defensa de lo patrimonial plantea hacia el exterior debe responder hacia el interior una exigencia equivalente en cuanto a la calidad de una investigación en la que se integren los aspectos naturales y culturales y una vivacidad en la búsqueda de la resonancia en el arte de nuestros días, como es el caso del land art, y en la confluencia con otros movimientos culturales confluyentes en los mismos objetivos. A su vez, la capacidad de transmisión hacia el exterior debe hacer inteligible a la sociedad de que no se trata de un mundo de sabios enfrascados en extrañas disquisiciones, sino de que se están afrontando problemas que afectan a los aspectos más acuciantes del momento.

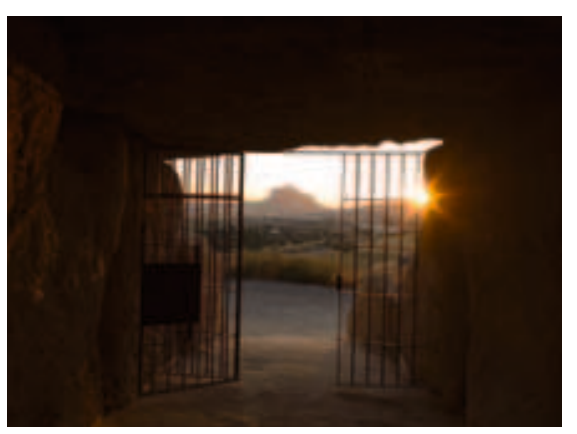

Vista de la Peña desde Menga. Foto: Javier Pérez González. Fuente: Conjunto Arqueológico Dólmenes de Antequera

Asi, frente a las estrategias basadas en el mero crecimiento, en las que una ciudad media siempre ocupará un segundo plano frente a las grandes metrópolis, debe hacerse manifiesto lo que significa la puesta en valor de unos recursos cualitativos sin parangón, como señuelo de atracción de actividades que requieren una excelencia en el entorno y que la acelerada destrucción de los espacios costeros tiende a desplazar hacia lugares hasta ahora mejor preservados.

El Plan Director del Conjunto Arqueológico Dólmenes de Antequera, con un período de vigencia que va de 2011 a 2018, es el instrumento que detecta sus necesidades y propone las líneas de trabajo para hacer efectiva su tutela.

Este año presentaremos el documento de avance de su Plan Director a través del proceso de institucionalización de la tutela de los Dólmenes de Menga y Viera y el Tholos de El Romeral, la definición de la institución mediante el planteamiento conceptual, asi como su análisis y evaluación, y finalmente los programas.
El Plan Director será el instrumento para racionalizar la actuación de la administración cultural en el Conjunto Arqueológico Dólmenes de Antequera. Dicho Plan incorporará el aspecto conceptual de la tutela de los bienes culturales, a través de los programas de revalorización de los activos que constituyen el núcleo de la institución (patrimonio y paisaje cultural: documentación, definición y conservación), los programas de actividades (difusión y comunicación, investigación, exposición y musealización) y los programas de administración que establecerán los elementos básicos para la organización de los instrumentos necesarios para llevarlos a cabo: el programa institucional, arquitectónico, de seguridad, de recursos humanos y económico.

El Plan Director del Conjunto Arqueológico Dólmenes de Antequera persigue los siguientes objetivos:

- Ejercer la tutela efectiva del Conjunto Arqueológico Dólmenes de Antequera entendida como un proceso integrado por diferentes acciones tendentes a su administración, investigación, protección, conservación, restauración y difusión que permita mantener y acrecentar dicho patrimonio.

- Vincular la tutela del Conjunto Arqueológico Dólmenes de Antequera con las políticas urbanística, medioambiental y turística, atendiendo a todos los aspectos que relacionan los bienes culturales con el espacio y el territorio, desde su consideración como paisaje cultural y con un uso sostenible.

- Impulsar la función de la institución como instrumento para la tutela y el acrecentamiento de los Dólmenes de Antequera.

- Enunciar y desarrollar nuevos modelos de gestión para la institución.

- Fomentar la investigación de la Historiografía asi como de la Prehistoria de Andalucía.

- Insertar los recursos patrimoniales en las estrategias y programas de desarrollo sostenible.

- Potenciar la función asesora de la administración consultiva.

- Promover la efectiva participación de la ciudadanía en las diversas acciones de la tutela del Conjunto Arqueológico Dólmenes de Antequera.

La elaboración de los programas que integran el Plan Director ha sido responsabilidad del Conjunto, aunque su carácter ha exigido, en algunos casos, la participación de equipos interdisciplinares con el fin de facilitar el trabajo de los profesionales responsables de elaborar los proyectos y establecer un lenguaje común desde el principio. Desde aquí queremos agradecer la implicación de todas las personas que han colaborado en la redacción.

José Ramón Menéndez de Luarca Navia Osorio Rosa Enríquez Arcas

Coordinadores del Plan Director

Nota

La dirección del Plan Director del Conjunto Arqueológico Dólmenes de Antequera está a cargo de Bartolomé Ruiz González. 


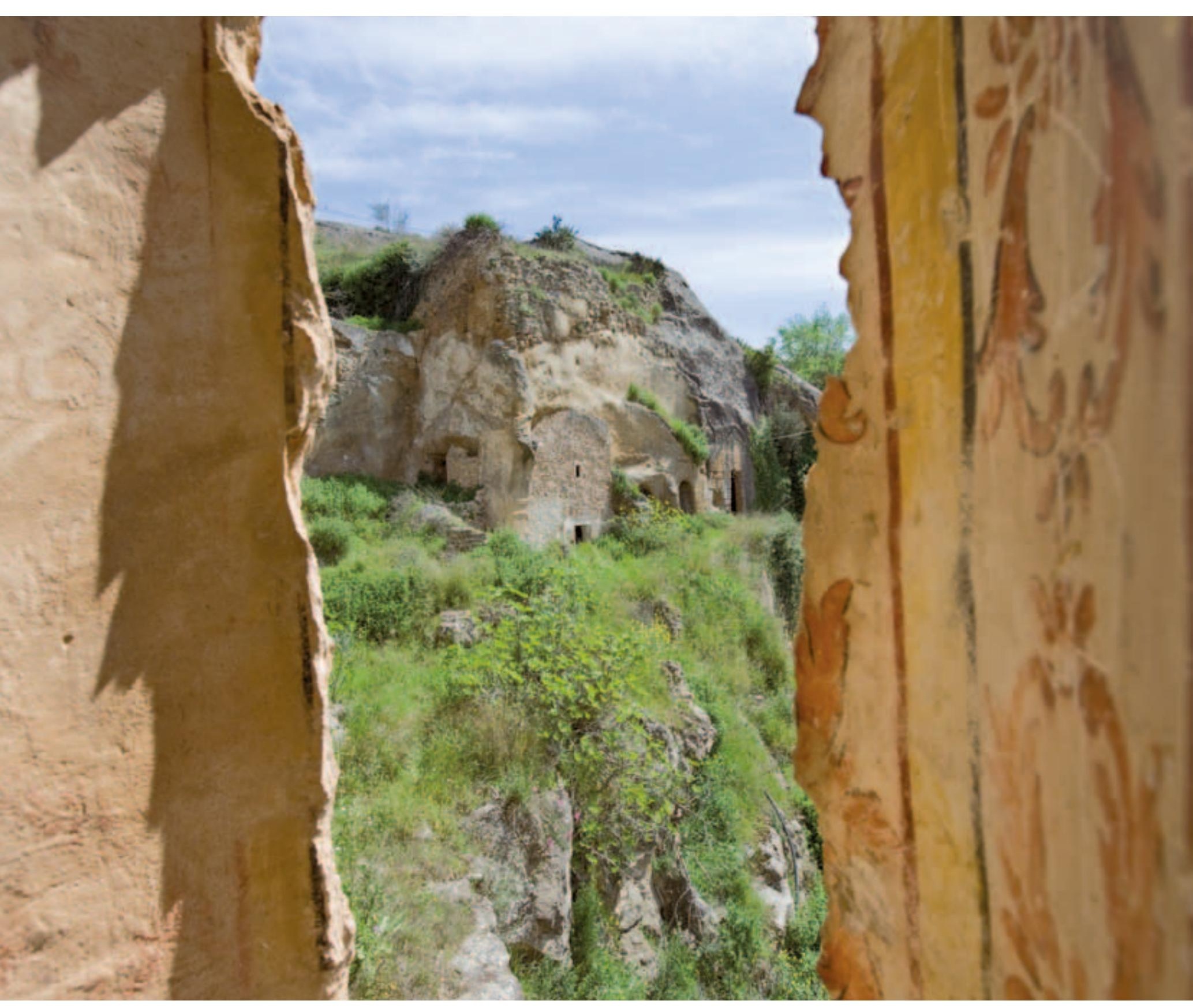

Vista general de la ermita rupestre de Villanueva de Algaidas desde el convento Recoletos de San Francisco de Asís.

Foto: Juan Carlos Cazalla, IAPH 


\section{Eremitorios rupestres de la comarca de Antequera}

\author{
M. ${ }^{\text {a }}$ Isabel Cisneros García, Taller de \\ Investigaciones Arqueológicas, S. L.; \\ Daniel García Blanco, Delegación \\ Provincial de Cultura de Málaga
}

Desde los Servicios Técnicos de la Delegación Provincial de Cultura de Málaga en los últimos años, se viene coordinando la recogida de información y redacción de inventarios del patrimonio histórico malagueño. Su carácter temático o su concreta adscripción territorial los hacian herramientas muy útiles a la hora de sistematizar determinados bienes o áreas específicas, pero adolecian de una visión de conjunto que permitiera evaluar la cuantía o entidad de los bienes en su totalidad. Intentando subsanar dichas deficiencias, realizando inventarios más genéricos o que englobaran ámbitos territoriales homogéneos, detectamos la presencia de este interesante patrimonio arquitectónico, que hasta el momento no contaba con ninguna herramienta para su protección y que, si bien algunas de sus manifestaciones eran ampliamente conocidas, el resto raramente se recogía en los catálogos, inventarios o planeamientos municipales.

Este interés se convirtió en una de las directrices que marcó la programación en los últimos años, coordinando desde el departamento de protección varios expedientes de catalogación que pretendian una recopilación exhaustiva de información sobre estos bienes. Durante el proceso de sistematización de la información fuimos documentando otros eremitorios, algunos de ellos desconocidos, otros no suficientemente investigados. Para ello fue fundamental la publicación, coincidente en el tiempo con el interés de la Consejería de Cultura, que realizó Rafael Puertas Tricas, en la que, a través de fichas, establece una comparación entre las diferentes construcciones rupestres de las provincia, recopilando los ejemplos más conocidos de este tipo de arquitectura.

Para la comprensión de este complejo patrimonio es necesario remontarse a la idea que genera esta particular arquitectura, ya que desde los orígenes del Cristianismo, la cueva se ha entendido como un lugar sagrado, con esta visión heredera del concepto de cueva como lugar de regeneración (MOLINA GÓMEZ, 2006: 863), como el símbolo del útero de la Madre Tierra (MOLINA GÓMEZ, 2006: 883). Ya en época antigua, el culto en cuevas está ampliamente documentado como lugar de nacimiento de dioses y ofrecimiento de oblaciones, tal sería el caso de Mitra, cuyo culto posee numerosas coincidencias con el Cristianismo desde sus origenes (MOLINA GÓMEZ, 2006: 863).
En concreto, en la ideología cristiana, la cueva se asociaba en origen al lugar de nacimiento de Cristo. A pesar de que este hecho no es recogido en los Evangelios, ya es citado en el Protoevangelium lacobi, texto apócrifo en el que se menciona como el lugar exacto del nacimiento (MOLINA GÓMEZ, 2006: 863). Este documento, no admitido en Occidente, sí gozó en Oriente de gran popularidad. Por tanto, tenemos que considerar que la cueva, en sí misma, posee una larga tradición en el cristianismo primitivo; además de lugar sagrado y de culto, éstas representan el lugar donde acuden los anacoretas a enfrentarse con los demonios y purificarse para alcanzar el verdadero conocimiento de Dios a través de la renuncia. La cueva simboliza el poder del demonio, donde el hombre acude a confrontarlo. Este modelo es transmitido por San Atanasio de Alejandría (s. IV), paradigma principal de los ascetas cristianos (MOLINA GÓMEZ, 2006: 872)'. Estos ascetas buscaban la fuga mundi, huir de lo material, de la vida urbana y de todas sus connotaciones con la idea de alcanzar una forma de vida en contacto más directo con la divinidad (YELO TEMPLADO, 1993: 455).

Las causas de la penetración de estos influjos orientales se han de buscar no solo a través de las numerosas peregrinaciones realizadas en busca de los lugares sagrados (siglos IV-VI), que vehicularon la aceptación de estas tradiciones, sino también en los frecuentes intercambios comerciales existentes entre el Imperio Bizantino y Occidente que posibilitan el fuerte proceso de aculturación. Asimismo las emigraciones de monjes provenientes de Oriente a causa de la rápida expansión del Islam y los enfrentamientos iconoclastas son otras de las causas de este fenómeno.

En el caso hispano el auge del eremitismo se encuadra entre los siglos VIII-IX, debido a la presión ejercida sobre la población cristiana por parte del Islam, hecho que culminará en época califal, siendo la obra de Martín de Dumio (s. VI) la piedra angular para la génesis del monacato en la península. En la Sententiae Patrum Aegipteorum se recopila ciento diez reglas ascéticas tomadas de la tradición monástica oriental, constituyendo el comienzo de su implantación en Occidente. 
Con la conquista de al-Andalus, concretamente en el año 713, se establecen una serie de pactos con la población cristiana en los que se hacian constar que "no cambiarian en nada su situación y que conservarían su derecho de soberanía y especialmente que no serían molestados en la práctica de su ley y que sus iglesias no serán incendiadas ni despojadas de los objetos de culto que alli se encuentren" (YELO TEMPLAD0, 1993: 456). Conforme se desintegra el sistema y organización visigoda, con la paulatina aunque no uniforme islamización de la población, vemos cómo la libertad religiosa condicionada al pago de altos impuestos provoca la ruina de muchos cristianos o visigodos, circunstancia que acelera su conversión, de modo que para finales del s. IX, según M. Acién, la población se encontraba prácticamente islamizada (ACIÉN ALMANSA, 1996: 189). A esto se le une la implantación del malikismo como elemento fundamental de presión que se instaura a partir de Hisham I. Por otro lado, a pesar de los pocos datos que se tienen de la Iglesia católica en época del Emirato, el papel de un sector oficial era el de colaborar con el gobierno musulmán (ACIÉN ALMANSA, 1997: 113), ya sea mediante la participación en concilios o por la aportación de censos de los súbditos cristianos, véase el caso del realizado en el año 862 por el Obispo de Málaga Ostégesis (MARTíNEZ ENAMORAD0, 2003: 64).

A lo largo de la geografía española, son abundantes los ejemplos de eremitorios rupestres. Entre ellos cabe destacar las cuevas de Herrera/San Felices en Burgos (ALONSO MARTíNEZ, 2006), Nájera o San Millán de Suso en La Rioja (PUERTAS TRICAS, 1974), así como la Cueva de la Camareta (Albacete). En Andalucía, el fenómeno del monacato, con epicentro en Córdoba, fue determinante, sobre todo durante el siglo IX que, aun siendo capital del Emirato Omeya, se convirtió también en el núcleo principal del cristianismo mozárabe. Este fenómeno fue consecuencia de la importante represión ejercida desde el gobierno central de Córdoba sobre las comunidades de la zona. La opresión, unida a la presión fiscal (YELO TEMPLADO, 1993: 457), que agravaba aún más la situación de los mozárabes cordobeses, provocó la huida de los cristianos fuera de las ciudades². El principal representante de este movimiento fue San Eulogio de Córdoba, que escribió una de las obras más influyentes de la época para el mundo mozárabe, el Memorial de los Mártires, donde se insta al movimiento martirial, así como Álvaro de Córdoba, autor del Indiculus luminosus, donde alertaba del peligro que suponía la islamización progresiva de la sociedad andalusí.

En el caso concreto de Málaga las principales manifestaciones tienen lugar durante los siglos VIII y IX, de ahí que la tendencia más acertada sea la propuesta por Manuel Acién en cuanto a la hora de establecer un ámbito cronológico, del que no debiéramos pasar del calificativo de altomedieval. Esta imprecisión cronológica es debida a que en ningún caso se han llevado a cabo actuaciones arqueológicas, ni siquiera se ha podido asociar estos edificios a restos de carácter mueble ni de cualquier otro tipo que puedan aportar dataciones algo más precisas. Esta tesis se complica aún más si intentamos relacionar este fenómeno monástico en Málaga con la fitna, algo que este autor considera probable pero no seguro, aunque si es cierto que, al menos en el caso de Málaga, estos centros están ubicados en las cercanias del núcleo de la base de operación, Bobastro.

El alejamiento de las ciudades provocó la creación de una vida no monástica en torno a los centros eremíticos, o como algunos autores lo han denominado, una "ruralización del hábitat" en torno a los monasterios (YELO TEMPLADO, 1993: 457). De la misma manera motivó también la separación de la jerarquía de la iglesia naciendo así el fenómeno de las iglesias rupestres. Estas comunidades no acatan las prohibiciones de construir templos sin el consentimiento del obispo (YELO TEMPLADO, 1993: 457); de este modo, las iglesias o ermitas rupestres pueden ser consideradas como el único testigo tangible que nos queda de un momento histórico complejo a la vez que oscuro en cuanto al conocimiento de las creencias y relaciones sociales, esencialmente debido a la escasez de fuentes. Representa el mundo social de la época y cómo se imbrican los diferentes grupos en la formación del incipiente estado islámico emiral participando, por un lado, los habitantes autóctonos, herederos de la población hispanovisigoda y, por otro, la sociedad islámica de un marcado carácter tribal con etnias de origen árabe y bereber.

En cuanto a la caracterización de esta tipología, las formas de arquitectura rupestre o semi-rupestre se encuentran muy vinculadas a estos primeros momentos del monasticismo hispánico, como heredero de estas corrientes filosóficas orientales, de cuya realidad se tiene constancia al menos desde el año 380, con la celebración del Concilio de Zaragoza. Bien es cierto que podria hacerse una distinción entre los diferentes tipos de "vida monástica" teniendo, por un lado, a aquéllos que preconizan la vida en soledad, como son los denominados eremitas o anacoretas, y, por otro, aquéllos que optan por una vida en comunidad. Ambos fenómenos se traducen en el campo de la arquitectura en edificaciones monásticas, para el primer caso, y cenobíticas, para el segundo. Sería conveniente remarcar que sociedades islámicas también practican el misticismo como fuerte influjo del ascetismo y monacato cristiano, ya que estos grupos cristianos estaban en constante relación con las tribus beduinas haciendo una importante labor misionera (MARTíNEZ LÓPEZ, 1998: 466). Sería la respuesta de contraposición frente al lujo y derroche de los primeros momentos del Islam (MARTíNEZ LÓPEZ, 1998: 467).

Dentro de la provincia de Málaga encontramos variados ejemplos, cuya característica común es la de encontrarse excavados completa o parcialmente en la roca. Estos espacios estaban destinados a la celebración de liturgias por parte de la comunidad mozárabe. Entre ellas destacan las ubicadas en la comarca de Antequera.

\section{ARCHIDONA}

La ermita rupestre de Archidona se sitúa en la plaza Ochavada, quedando incluida en el casco urbano e integrada en dos inmuebles colindantes. Uno de ellos es actualmente un restaurante, que aprovecha cuatro de las cinco naves de la iglesia, mientras que la 

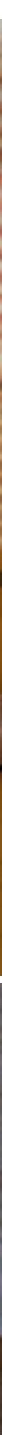

Distintas vistas del interior de la ermita rupestre de Archidona, actual bar La Cueva, en la plaza Ochavada. Fotos: Juan Carlos Cazalla, IAPH

restante se ubica en el inmueble inmediato. Morfológicamente, las tres naves centrales son prácticamente paralelas y se constituyen como el núcleo principal del conjunto. Destaca la existencia de un pasillo que las intercomunicaba y puede asimilarse a un crucero, de ahi que las que quedan incomunicadas serian utilizadas como verdaderas habitaciones eremíticas. No se han conservado elementos de indole litúrgica, las transformaciones efectuadas en la misma para la adecuación de este espacio al uso como restaurante han desvirtuado la altura original de estas cuevas, quedando la cota del suelo actual por encima del original.

\section{VILLANUEVA DE ALGAIDAS}

Villanueva de Algaidas resalta como un conjunto de especial importancia y belleza, donde el entorno visual es sumamente importante para su comprensión y contemplación. Se trata de una ermita de pequeñas dimensiones, excavada en la roca arenisca que cuenta con dos galerías que no se comunican entre sí más que por el exterior. Constatamos que el terreno circundante a la iglesia rupestre se encuentra alterado de antiguo pues puede evidenciarse que la excavación de un talud ha hecho desaparecer parte del edificio en su extremo norte, en concreto nos referimos a un arranque de arco seccionado, cuyo espacio habitacional se desarrollaría hacia el desnivel. La nave de la iglesia propiamente dicha es de tendencia rectangular y cubierta por una bóveda de cañón. Al fondo de esta nave tenemos la cabecera de la iglesia con una excavación bajo arco de medio punto que simularía el ábside, orientado hacia el este y sin reminiscencias de altar; este espacio principal conserva dos habitáculos más. El ubicado hacia el norte cuenta con acceso desde el exterior, comunicado con la nave principal mediante un vano adintelado; posee una hornacina excavada y lo que puede ser un banco corrido. La estancia meridional es de planta trapezoidal y tiene una pila excavada en el terreno, lo que da pie a dilucidar que estemos ante el "baptisterio". Hacia el oeste y con ingreso directo del exterior, vemos que se abre una cavidad menor, de tendencia rectangular, cuya funcionalidad se atribuye al lugar de habitación del propio eremita. El flanco de la celda que se orienta hacia el sur presenta una "fachada" de obra. 


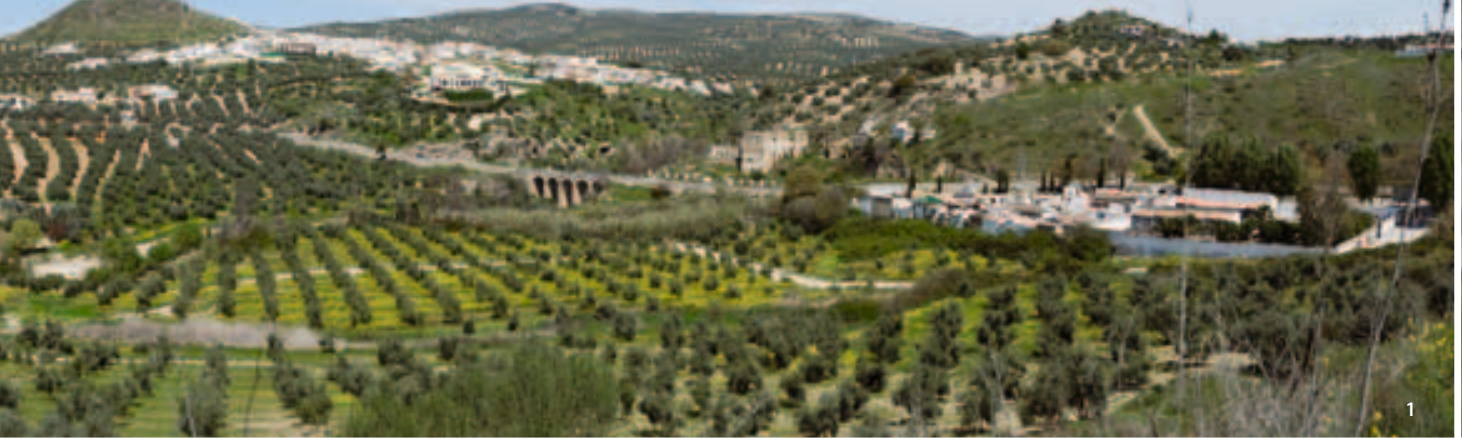
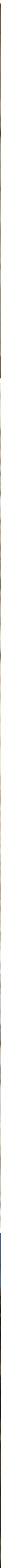

1. Vista general del entorno donde se encuentra la ermita rupestre de Villanueva de Algaidas. Foto: Juan Carlos Cazalla, IAPH

2. Cruz en el eremitorio rupestre de Algaidas. Foto: $M^{a}$ Isabel Cisneros García

7. Convento de San Francisco. Foto: Mª Isabel Cisneros García 


\section{ANTEQUERA}

Dado a conocer también por Rafael Puertas, este eremitorio se distingue de los ya mencionados por sus reducidas dimensiones aunque hoy dia se encuentra inaccesible a causa de un desplome rocoso sobre el acceso. Su protección legal queda convenientemente impuesta a través del Catálogo de yacimientos arqueológicos del PGOU municipal.

En general, los eremitorios ubicados en la provincia han tenido un uso continuado en el tiempo. Los localizados en ámbito rural, como almacenes o covachas para el ganado; los más cercanos a núcleos urbanos, como hábitat, comercio, restauración, etc. Usos que, si bien en casos concretos no han resultado muy lesivos, en general han dañado las estructuras así como el sustrato arqueológico de ocupación. La ubicación privilegiada del eremitorio de Archidona, en plena plaza Ochavada, hace que las transformaciones sean numerosas; en concreto, este ejemplo ha sufrido varias intervenciones para adecuarlo a su actual función como restaurante. Entre ellas cabe destacar la elevación de la cota de suelo con respecto a la original, revestimiento con zócalos y encalado de las paredes así como la adición de elementos decorativos y cableado eléctrico. Muy diferente es el caso de Villanueva de Algaidas que se mantiene más o menos intacto hasta nuestros dias, preservando incluso las funciones culturales del espacio con la construcción del convento de San Francisco en las inmediaciones, encontrándose hoy en día dicho conjunto en estado de abandono.
Estos magníficos ejemplos de arquitectura rupestre quizá no sean tan monumentales como los documentados en los núcleos en Castillas León o La Rioja, siendo el principal exponente del grupo malagueño la iglesia rupestre de las Mesas de Villaverde, ampliamente conocida por la investigación, que junto a la de la Oscuridad en Ronda inducen a Puertas Tricas a considerar la existencia de un núcleo de arte mozárabe en la provincia, que queda focalizado en esas dos iglesias de tres ábsides en la cabecera. El resto de los inmuebles es considerado por este autor como un "pálido reflejo" (PUERTAS TRICAS, 1989: 26).

A pesar de la cantidad de estudios que sobre este tipo de arquitectura existe en todo el ámbito peninsular, hasta el momento siempre han estado reducidos a comarcas concretas (véase Málaga, La Rioja, Tarragona, León...) sin que se hayan realizado investigaciones que abarquen una perspectiva más amplia, ofreciendo una visión de conjunto de este fenómeno de arquitectura rupestre, cuyo desarrollo se adscribe a un momento cronológico preciso, en torno a los siglos VIII-X d. C. Esperamos que poco a poco se vayan detectando y estudiando otros ejemplos en la comunidad autónoma que brinden una visión de conjunto y unifiquen el conocimiento fragmentario que poseemos en la actualidad.

\section{Notas}

'En su obra Vita Antonii relata cómo el protagonista de los hechos pasó dos años en una cueva enfrentándose a los demonios y finalmente salió victorioso.

${ }^{2}$ Un ejemplo de esto es la orden de Muhammad I (852-886) de derribar algunas basílicas de la capital cordobesa.

\section{En la web}

\section{CONSEJERÍA DE CULTURA. JUNTA DE ANDALUCÍA}

www.juntadeandalucia.es/cultura

Sitio web oficial de la Consejería de Cultura de la Junta de Andalucía. La Red de Espacios Culturales en la sección Bienes Culturales ofrece información sobre el Conjunto Arqueológico Dólmenes de Antequera; localización, contacto, datos históricos de la necrópolis megalítica, documentación de interés y galeria de imágenes.

CONSEJERÍA DE MEDIO AMBIENTE. JUNTA DE ANDALUCÍA

www.juntadeandalucia.es/

medioambiente

Información completa y exhaustiva del Paraje Natural Torcal de Antequera y la Reserva Natural Laguna de Fuente de Piedra en el sitio web oficial de la Consejería de Medio Ambiente de la Junta de Andalucia. Régimen de protección, localización y accesos, información cartográfica, equipamientos, mapas de vegetación, publicaciones y galería de imágenes son algunos de los datos que podrá consultar en esta web.

\section{DIPUTACIÓN DE MÁLAGA}

www.malaga.es

El sitio web de esta institución pública ofrece información de interés sobre la comarca de Antequera. Fichas descriptivas de los municipios que la conforman con datos sobre su patrimonio cultural.

\section{AYUNTAMIENTO DE ANTEQUERA www.antequera.es}

Recorrido por el patrimonio cultural y natural de Antequera, historia y fondos del Archivo Municipal ofrece el sitio web de este organismo público.

\section{AYUNTAMIENTO DE ARCHIDONA \\ www.archidona.es}

La web oficial del Ayuntamiento de este municipio dedica un espacio al rico y variado patrimonio cultural de las cofradias de Archidona.

\section{FORO DE PATRIMONIO HISTÓRICO DE ANTEQUERA. DOLMEN DE MENGA}

www.dolmendemenga.org

Heredero de la asociación del mismo nombre, este foro pretende difundir y promover el patrimonio cultural de Antequera. Historia de Antequera, vinculaciones con Francia y México, itinerarios y publicaciones podrá encontrar en su web.

\section{FUNDACIÓN DOCOMOMO IBÉRICO}

Www.docomomoiberico.com

Fundación que coordina los objetivos de DOCOMOMO internacional en España y Portugal. En su web se posibilita la consulta de la base de datos con información de las obras incluidas en los Registros de la Industria y de la Vivienda de DOCOMOMO Ibérico.

\section{ASOCIACIÓN ISLA DE ARRIARÁN www.isladearriaran.com}

Asociación cultural dedicada a promover la actividad científica en torno al patrimonio cultural de Málaga. Edita la revista del mismo nombre cuyos indices se encuentran disponibles en su sitio web. 


\section{ANTEQUERA}

Dado a conocer también por Rafael Puertas, este eremitorio se distingue de los ya mencionados por sus reducidas dimensiones aunque hoy dia se encuentra inaccesible a causa de un desplome rocoso sobre el acceso. Su protección legal queda convenientemente impuesta a través del Catálogo de yacimientos arqueológicos del PGOU municipal.

En general, los eremitorios ubicados en la provincia han tenido un uso continuado en el tiempo. Los localizados en ámbito rural, como almacenes o covachas para el ganado; los más cercanos a núcleos urbanos, como hábitat, comercio, restauración, etc. Usos que, si bien en casos concretos no han resultado muy lesivos, en general han dañado las estructuras así como el sustrato arqueológico de ocupación. La ubicación privilegiada del eremitorio de Archidona, en plena plaza Ochavada, hace que las transformaciones sean numerosas; en concreto, este ejemplo ha sufrido varias intervenciones para adecuarlo a su actual función como restaurante. Entre ellas cabe destacar la elevación de la cota de suelo con respecto a la original, revestimiento con zócalos y encalado de las paredes así como la adición de elementos decorativos y cableado eléctrico. Muy diferente es el caso de Villanueva de Algaidas que se mantiene más o menos intacto hasta nuestros dias, preservando incluso las funciones culturales del espacio con la construcción del convento de San Francisco en las inmediaciones, encontrándose hoy en día dicho conjunto en estado de abandono.
Estos magníficos ejemplos de arquitectura rupestre quizá no sean tan monumentales como los documentados en los núcleos en Castillas León o La Rioja, siendo el principal exponente del grupo malagueño la iglesia rupestre de las Mesas de Villaverde, ampliamente conocida por la investigación, que junto a la de la Oscuridad en Ronda inducen a Puertas Tricas a considerar la existencia de un núcleo de arte mozárabe en la provincia, que queda focalizado en esas dos iglesias de tres ábsides en la cabecera. El resto de los inmuebles es considerado por este autor como un "pálido reflejo" (PUERTAS TRICAS, 1989: 26).

A pesar de la cantidad de estudios que sobre este tipo de arquitectura existe en todo el ámbito peninsular, hasta el momento siempre han estado reducidos a comarcas concretas (véase Málaga, La Rioja, Tarragona, León...) sin que se hayan realizado investigaciones que abarquen una perspectiva más amplia, ofreciendo una visión de conjunto de este fenómeno de arquitectura rupestre, cuyo desarrollo se adscribe a un momento cronológico preciso, en torno a los siglos VIII-X d. C. Esperamos que poco a poco se vayan detectando y estudiando otros ejemplos en la comunidad autónoma que brinden una visión de conjunto y unifiquen el conocimiento fragmentario que poseemos en la actualidad.

\section{Notas}

'En su obra Vita Antonii relata cómo el protagonista de los hechos pasó dos años en una cueva enfrentándose a los demonios y finalmente salió victorioso.

${ }^{2}$ Un ejemplo de esto es la orden de Muhammad I (852-886) de derribar algunas basílicas de la capital cordobesa.

\section{En la web}

\section{CONSEJERÍA DE CULTURA. JUNTA DE ANDALUCÍA}

www.juntadeandalucia.es/cultura

Sitio web oficial de la Consejería de Cultura de la Junta de Andalucía. La Red de Espacios Culturales en la sección Bienes Culturales ofrece información sobre el Conjunto Arqueológico Dólmenes de Antequera; localización, contacto, datos históricos de la necrópolis megalítica, documentación de interés y galeria de imágenes.

CONSEJERÍA DE MEDIO AMBIENTE. JUNTA DE ANDALUCÍA

www.juntadeandalucia.es/

medioambiente

Información completa y exhaustiva del Paraje Natural Torcal de Antequera y la Reserva Natural Laguna de Fuente de Piedra en el sitio web oficial de la Consejería de Medio Ambiente de la Junta de Andalucia. Régimen de protección, localización y accesos, información cartográfica, equipamientos, mapas de vegetación, publicaciones y galería de imágenes son algunos de los datos que podrá consultar en esta web.

\section{DIPUTACIÓN DE MÁLAGA}

www.malaga.es

El sitio web de esta institución pública ofrece información de interés sobre la comarca de Antequera. Fichas descriptivas de los municipios que la conforman con datos sobre su patrimonio cultural.

\section{AYUNTAMIENTO DE ANTEQUERA www.antequera.es}

Recorrido por el patrimonio cultural y natural de Antequera, historia y fondos del Archivo Municipal ofrece el sitio web de este organismo público.

\section{AYUNTAMIENTO DE ARCHIDONA \\ www.archidona.es}

La web oficial del Ayuntamiento de este municipio dedica un espacio al rico y variado patrimonio cultural de las cofradias de Archidona.

\section{FORO DE PATRIMONIO HISTÓRICO DE ANTEQUERA. DOLMEN DE MENGA}

www.dolmendemenga.org

Heredero de la asociación del mismo nombre, este foro pretende difundir y promover el patrimonio cultural de Antequera. Historia de Antequera, vinculaciones con Francia y México, itinerarios y publicaciones podrá encontrar en su web.

\section{FUNDACIÓN DOCOMOMO IBÉRICO}

Www.docomomoiberico.com

Fundación que coordina los objetivos de DOCOMOMO internacional en España y Portugal. En su web se posibilita la consulta de la base de datos con información de las obras incluidas en los Registros de la Industria y de la Vivienda de DOCOMOMO Ibérico.

\section{ASOCIACIÓN ISLA DE ARRIARÁN www.isladearriaran.com}

Asociación cultural dedicada a promover la actividad científica en torno al patrimonio cultural de Málaga. Edita la revista del mismo nombre cuyos indices se encuentran disponibles en su sitio web. 


\section{La ciudad romana de Singilia Barba. La materialización de una herencia}

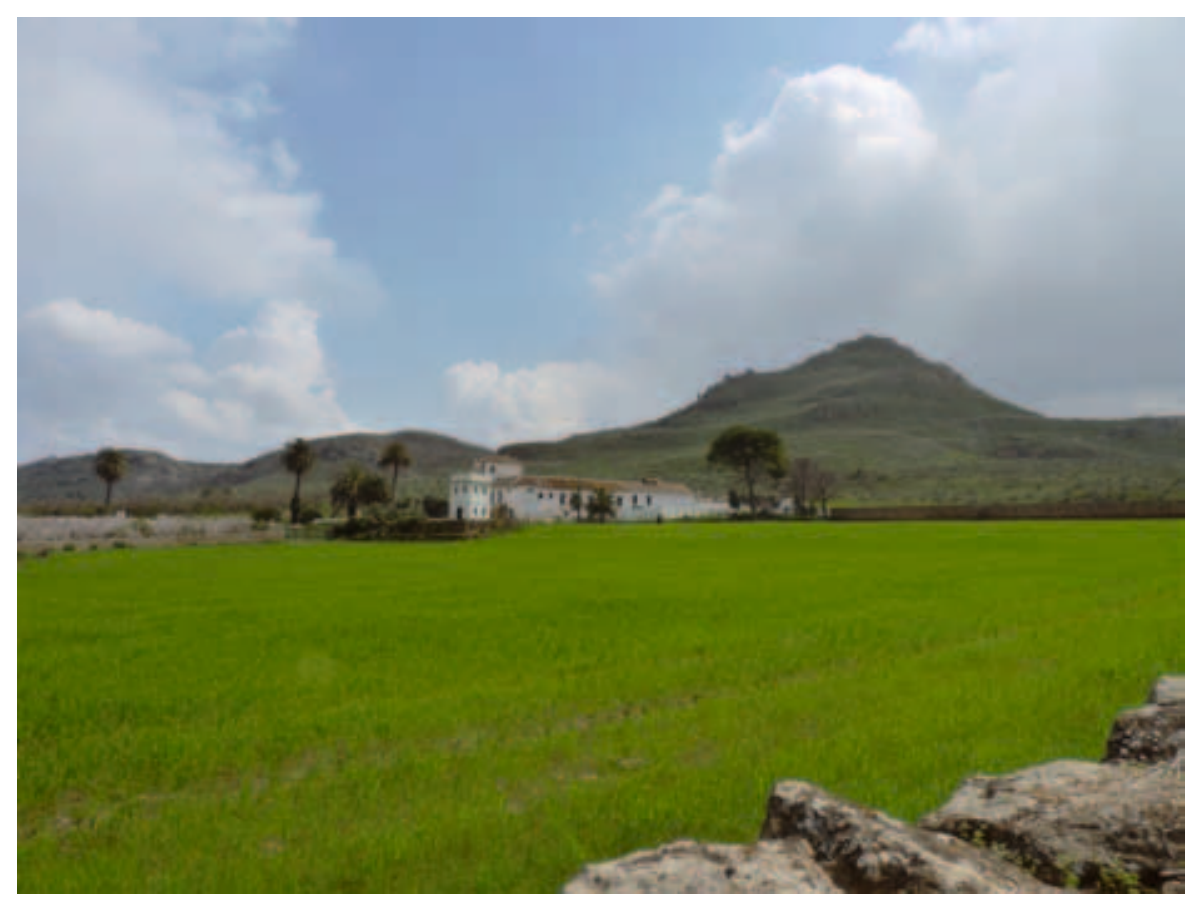

Cortijo y cerro del Castillón al fondo. Foto: Juan B. Fernández Luque, 2010

Hasta no hace muchos años, cuando el viajero ascendia el Puerto de las Pedrizas y su mirada caía sobre la vega de Antequera, al viso de la Cuesta de El Romeral, podía observar un hermoso paisaje agrario de tonos verdes y ocres, tachonado de blancas cortijadas, en cuyos patios y exteriores se elevaban las oscuras manchas de los cipreses. Este árbol, tan asociado en nuestra mente a las recreaciones de las villae romanas, también jalonaba los caminos, de modo que la vista general evocaba en el espectador paisajes de otros tiempos más remotos que hoy hemos sacrificado en busca de la modernidad. En este corazón viario de Andalucía, en un paisaje no muy distinto al descrito, se fundó la ciudad romana de Singilia Barba, abalconada sobre el territorio que la circunda.

Pero, ¿cómo explicarnos la configuración de un paisaje antiguo, del que además los antequeranos modernos somos deudores? Al igual que nosotros recurrimos al análisis del pasado, profundizando en las aportaciones históricas que proporciona la Singilia romana para tener una noción más clara de nuestro presente, asi deberemos profundizar en la historia de la ciudad romana, al objeto de comprender mejor su implantación sobre el paisaje.

La vega de Antequera es desde la Prehistoria una de las comarcas naturales andaluzas más frecuentadas por el hombre. No obstante, la humanización del paisaje no se vio acelerada hasta las fases recientes del Neolítico y, fundamentalmente, a lo largo del Calcolitico. Primero, grupos itinerantes recorrieron estacionalmente sus parajes más aptos. Con el correr del tiempo, las bonanzas climáticas y el potencial económico de la llanura y los piedemontes que la circundan favorecieron la evolución de las estructuras sociales y la consolidación de hábitats estables en aquellos puntos que reunían mejores condiciones para el control del territorio. De una constelación de pequeños asentamientos neolíticos, surge en el Cerro del Castillón un poblado calcolitico, cuya continuidad durante las diversas etapas de la Edad del Bronce serán el germen de un potente oppidum ibérico que posibilitará, con la llegada de los romanos, la fundación de Singilia (ATENCIA PÁEZ, 1988: 42).

Sobre el origen de la ciudad como tal, hoy sabemos que se adaptaron y reforzaron las antiguas murallas pertenecientes al oppidum ibérico con una carga de simbolismo que supera su utilidad poliorcética real.

No obstante, y en virtud de los datos relativamente abundantes proporcionados por la arqueologia antequerana, debemos proponer ciertos matices en cuanto a los fenómenos que se enmascaran tras la romanización de la zona. Tradicionalmente

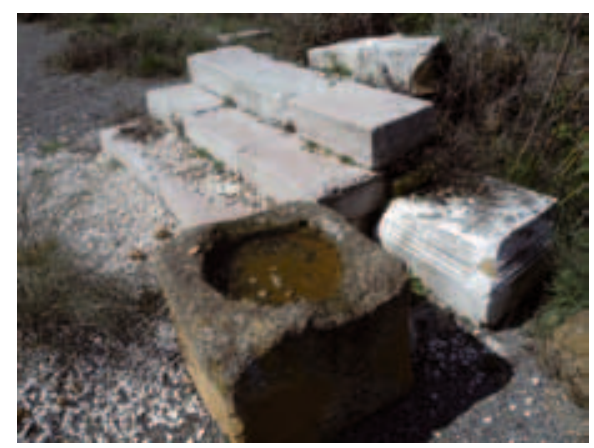

Foro de Singilia, escalinata de marmora del torcal que daba acceso a uno de los pequeños templos. Foto: J. A. Suárez, 2010 se ha considerado que la asunción de los nuevos parámetros llegados con la romanización se produjo con prontitud en el ámbito de la Baetica; sin embargo, este modelo interpretativo parece cuestionarse en el caso del territorio antequerano. Se impone una clarificación de datos que de manera objetiva corrija aquellos tópicos tradicionalmente acomodados en la historiografía sobre esta temáti$c a$, ofreciendo nuevos elementos de juicio para una veraz interpretación. Lo cierto es que, a partir de los trabajos arqueológicos más recientes, sabemos que el entramado de villas dependientes de Singilia no se construye con anterioridad al cambio de Era. Los restos materiales de cronología más temprana pueden ser considerados como elementos residuales en sus registros, asociados con precisión a depósitos erosivos y alterados, o bien insertos en sus cimentaciones, que en modo alguno pueden vincularse a sus fundaciones, sino más bien parecen relacionarse con evidencias de pequeñas explotaciones agropecuarias de tradición indigena con escasos programas edilicios. Será a partir de la época Flavia, en la segunda mitad del siglo I d. C., cuando se produce la ocupación intensiva del territorio, en especial del ager anticariense y singiliense. No es casual que Anticaria obtenga su estatuto de municipalidad, probablemente latina; con el emperador Galba y Singilia se constituya en municipio latino con el singular título de municipium flavium liberum singiliense, conservando en esta titulatura la referencia evidente a su antiguo estatus de ciudad libre.

En cualquier caso, como podemos observar, la llegada de los romanos al enclave no supuso una novedad en lo que se refiere al poblamiento. Las evidencias arqueológicas revelan que el gran monte de aspecto piramidal que domina la ciudad alojó desde el siglo $V$ antes de la era un importante núcleo de población ibérica, asentado precisamente sobre la elevación mejor protegida, dominando por su altimetría el extremo occidental de la vega. La ciudadela ibérica, configurada como un auténtico oppidum aterrazado, ocupó las cotas altas del Castillón, como atestigua el potente lienzo de muralla que aún altera el perfil natural de la ladera. Con la fundación de la ciudad romana, a sus pies y en la falda del mismo, podemos suponer que la población indigena quedaria rápidamente asimilada entre los contingentes plenamente romanizados.

La misma estructura de ciudad aterrazada parece mostrar también la Singilia romana; las excavaciones sistemáticas realizadas hasta la fecha se centraron sobre un espacio forense situado en una de las terrazas de la ladera media. Estos trabajos permitieron excavar varios templos de reducidas dimensiones, del tipo aedicula, así como un espacio despejado finamente enlosado con grandes lastras pétreas que daba acceso a un recinto basilical revestido de marmora locales, mostrando sitiales del mismo material que recorren su perimetro interno, apoyados sobre remates con forma de garra de felino (SERRANO RAMOS et ál., 1991: 277). En la terraza inmediatamente inferior, se encuentra otro de 


\section{Podemos suponer que \\ la visión desde la propia ciudad hacia su ager circundante debía ser una clara expresión de la feracidad de su agro. Seguramente no muy distinto al que podemos \\ contemplar hoy}

fundidad, en espera de que la Arqueología desvele sus misterios.

En la terraza baja, conectando con el plano aluvial que da paso a la margen izquierda del río Guadalhorce, el análisis de las fotografias aéreas y los hallazgos epigráficos han permitido descubrir la presencia de un circo de notables dimensiones. El posterior reconocimiento del terreno nos invita a pensar en su excepcional estado de conservación. Vemos cómo los grandes edificios públicos del municipio romano se estructuraron de forma escalonada a favor de la pendiente del Cerro del Castillón, distribuyéndose las residencias urbanas, domus, tanto al pie del mismo como en sus vertientes; sólo tres de ellas se han documentado parcialmente hasta la fecha (SERRANO RAMOS et ál., 1991: 275).

La necrópolis principal estuvo situada en la vertiente occidental y flanqueando la calzada que daba acceso a la ciudad desde el oeste tras cruzar el actual

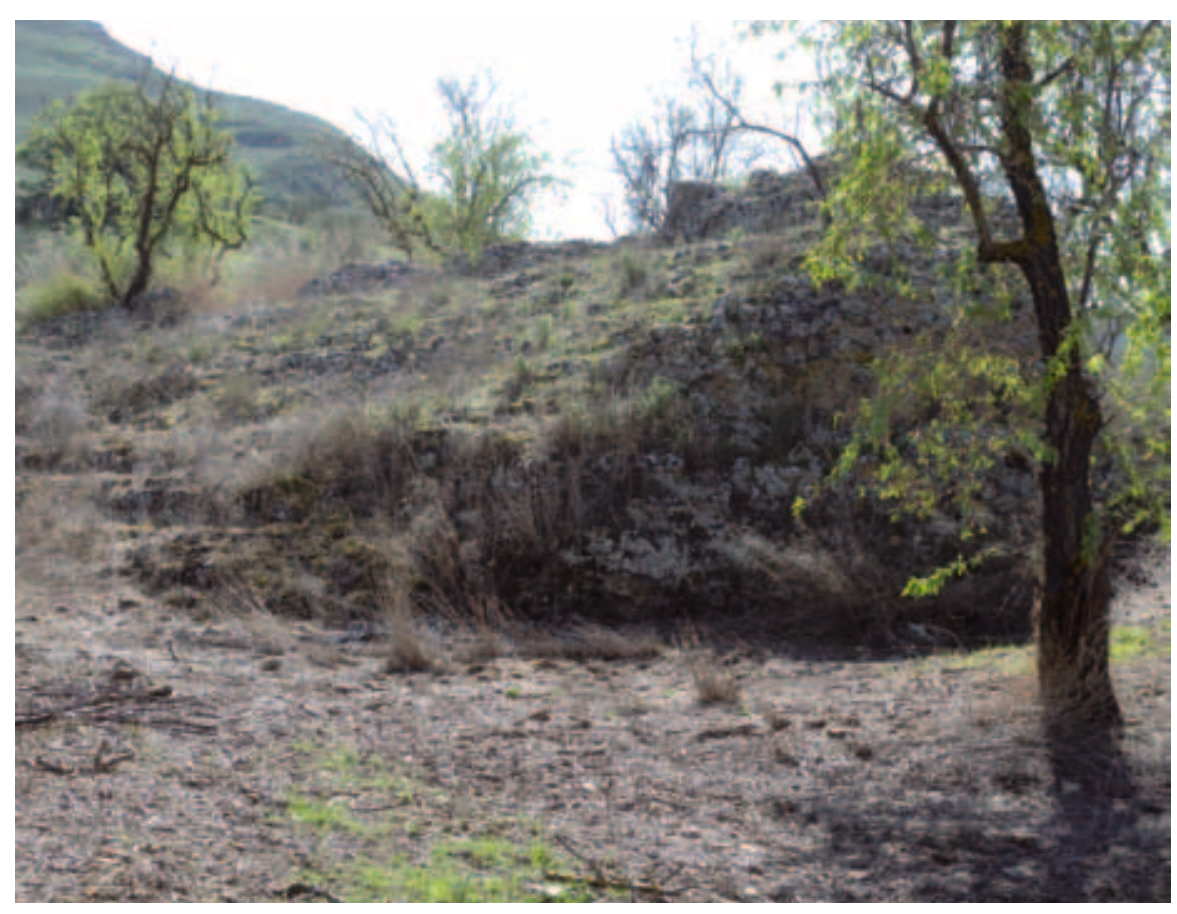

Vista del extremo oeste de la summa cavea del teatro romano de Singilia Barba. Foto: J. A. Suárez, 2010

los edificios paradigmáticos de las ciudades romanas, el teatro. Aún sin excavar, su conocimiento se remonta al siglo XVI, según trasmiten los cronistas de la época. Un siglo después, parte de sus sillares fue desgajados del graderío alto y reutilizados en la construcción de la iglesia antequerana de San Juan de Dios (ATENCIA PÁEZ, 1988: 54). Los grabados de la época así lo atestiguan. Recientemente se han acometido exploraciones geofísicas con modernas técnicas de RADAR de suelo que revelan que sus estructuras, hoy tapizadas por los derrubios coluviales de ladera, yacen en buen estado a 15 metros de pro- arroyo de Valsequillo. Se conocen varios mausoleos monumentales de tipo columbario, elaborados con bóvedas de sillería (FERNÁNDEZ RODRÍGUEZ; ROMERO RÉREZ, 2007: 18).

Podemos suponer que la vista de la ciudad romana, con sus grandes edificios públicos ricamente ornamentados e implantados en los resaltes naturales del Castillón, rodeados por los viales urbanos y el caserío de la ciudad, debía mostrarse al viajero de la Antigüedad como un marco escénico ciertamente espectacular e impactante. No obstante podemos suponer que la visión desde la propia ciudad hacia su ager circundante debía ser una clara expresión de la feracidad de su agro. Seguramente no muy distinto al que podemos contemplar hoy, con amplias extensiones de cereal y en virtud de la cincuentena de villas rústicas descubiertas en la comarca dedicadas a la producción de aceite, pobladas por densos manchones de olivar (ROMERO PÉREZ, 1998: 139).

No sólo la ciudad trasmite noción de riqueza con sus magnificas construcciones públicas, también su entorno se pobló de establecimientos rústicos y grandes villae, algunas como la de Bobadilla, verdaderos vicus con orientaciones tan diversificadas que no se limitaban a la explotación agropecuaria de sus tierras, sino que incluian producción de vasos cerámicos de consumo y almacenaje, asi como materiales constructivos ejecutados en los barros locales, transformación de menas minerales metálicas $y$, evidentemente, incluian áreas domésticas y de recreo, así como grandes ámbitos funerarios situados en torno a los principales caminos. De buena cuenta de ello dio la excavación de la necrópolis de la Villa de las Maravillas, cercana al curso del río e interpretada como residencia de recreo de uno de los personajes singilienses mejor conocidos, Acilia Plecusa, antigua esclava y liberta que casó con un miembro del orden ecuestre, M. Acilio Fronton, quien ostentó el cargo de praefectus fabrum. De su relación directa con la citada villa, sabemos gracias a la excavación de su impresionante mausoleo, planteado en su concepción primigenia como un gran columbario de sillares para recibir urnas de incineración que, por mor de los cambios en las "modas" de los rituales funerarios, terminó acogiendo los restos mortales de Acilia, inhumados en un sarcófago monolítico (ROMERO PÉREZ, 1994: 219).

Podemos concluir que los límites del territorio singiliense vienen dados por el conocimiento, tanto de la alineación de los ejes que orientan la planificación urbana y que, siguiendo las pautas romanas, se perpetúan en su ager de influencia, trazados con rumbo suroeste-noreste, como del punto de captación de aprovisionamiento de aguas para la ciudad, fijado en el Arroyo del Alcázar, desde donde se han descubierto algo más de seis kilómetros del acueducto que servía a Singilia y que, ya en el siglo XVII, el Padre Cabrera describía cuando explicaba las fórmulas de llenado de la naumaquia: "...y el agua que entrava enella setraia de el arroyo de el Alcazar por donde oy esta la pressa y Xavoneria donde se Juntava el agua que oy biene a Antequera, y se traia encañada por arcaduces de Piedra y argamassa por las Laderas de los olibares del partido que dizen de Sotomando hasta entrar en la Laguna..." (sic). Quedando así fijados los límites territoriales, Anticaria al este y Singilia al oeste (ROMERO PÉREZ, 2010).

Manuel Romero Pérez, Oficina Municipal de Patrimonio Histórico, Ayto. de Antequera

Luis Efrén Fernández, Teatro Romano de Málaga,

Consejería de Cultura de la Junta de Andalucia 


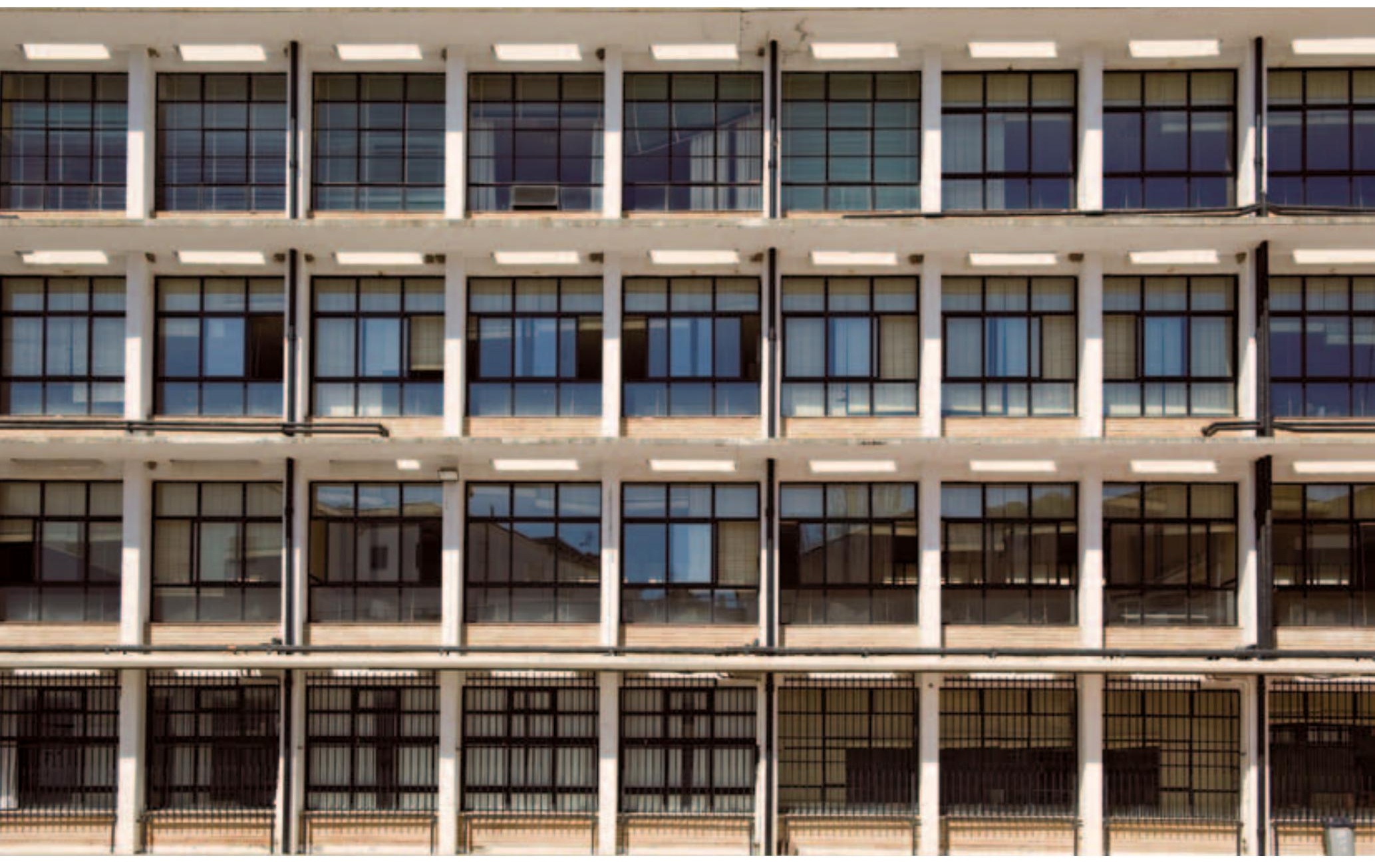

Detalle de la fachada de las aulas del instituto Pedro Espinosa que dan al patio interior con amplios huecos acristalados. Foto: Juan Carlos Cazalla, IAPH 


\section{La modernidad arquitectónica en Antequera: dos edificios y una modesta proposición}

Sebastián del Pino Cabello, arquitecto
La inexistencia de una guia de arquitectura en Antequera que relacione los edificios singulares de la ciudad, salvo trabajos puntuales publicados o la Guía Artística (ROMERO BENITEZ, 1989), no ha permitido hasta el momento poder conocer cuál ha sido la evolución, el desarrollo y las relaciones de sus construcciones de interés arquitectónico. Sabiendo de unos orígenes megalíticos de importancia que nos sirven de referencia y punto de partida en el panorama local, así como toda una sucesión de construcciones de cada una de las etapas históricas que conforman el desarrollo y evolución de Antequera, podemos constatar la existencia de un "corpus edilicio" que configura un catálogo arquitectónico propio que abarca el periodo desde la conquista cristiana en el inicio del siglo XV hasta nuestros días. Con anterioridad a este periodo, sólo la Arqueología podrá aportarnos los datos suficientes que nos dé a conocer otras existencias anteriores.

Sabemos de los yacimientos de la antigua ciudad romana de Antikaria (su emplazamiento, traza de calles y edificios) a través de los cimientos y arranques de muros, mosaicos en el peristilo de las villas, ninfeos de alguna terma o clípeo de algún morador. También conocemos de otros restos de culturas posteriores que nos hacen suponer la existencia de una población que con mayor o menor desarrollo estuvieron presentes y se perpetuaron a lo largo de los siglos. Así, el estudio y conocimiento de todos estos referentes históricos constituyen ese posible catálogo de arquitectura, iniciándose en la Alcazaba de la medina musulmana Antaqira, ya recogido anteriormente por el Plan Especial de Protección y Reforma Interior PEPRI o el Plan General de Ordenación Urbana, y que nos permitirá configurar todo un grupo de actuacionesconstrucciones fijadas en el tiempo, para alcanzar las claves que conforman el conjunto patrimonial arquitectónico de la ciudad. Conocer la historia de la ciudad (PAREJO BARRANCO, 1987) nos permite tener una visión general y también sectorial del proceso, desarrollo y evolución de la sociedad antequerana en muy diferentes aspectos, todos ellos necesarios y relacionados, y, como resultado último, el hecho constructivo y su arquitectura; arquitectura entendida como el exponente de una actividad que refleja el poder económico, político, social y cultural.
La etapa que podemos situar inmediata a los movimientos artísticos europeos en los inicios del siglo XX, que derivaria en el movimiento moderno, denominado en arquitectura "estilo internacional", alcanzó también en nuestro país sobresalientes resultados. Ejemplos que fueron extendiéndose y relacionándose por todo el territorio nacional, manifestaciones puntuales en los inicios, pero más numerosos seguidamente. Recordemos el registro Do.Co.Mo.Mo. Ibérico (1925-1965), amplio abanico y variedad que recoge las construcciones industriales, de equipamiento y vivienda. En el caso de Andalucia, existen suficientes ejemplos que vienen a constituir un conjunto heterogéneo y variado de gran sensibilidad y ejercicio estilistico. El periodo que abarca los años entre 1925 a 1936, momento del alzamiento militar, fue sin lugar a dudas una etapa definida arquitectónicamente, que continuaría posteriormente.

Durante este periodo, en Antequera, diferentes edificios se construyen obedeciendo a criterios estéticos bien diferenciados. Unos se dejan llevar por formas y composiciones siguiendo pautas anteriores y habituales; otros optan por líneas compositivas novedosas que traen a la ciudad un panorama estético diferenciador. Entre ellos sobresalen, con mayor o menor interés, edificios como el antiguo Banco Central, los Juzgados, y viviendas de la calle Infante como la Casa Bouderé, la familia Cruces o el edificio de San Luis. Se proyectan y construyen varios edificios que podemos denominar "modernos" y alguno apunta hacia la "arquitectura del regionalismo", como un proyecto de Anibal González con destino de vivienda (hoy oficinas de la administración).

Identificamos tres edificios como los que podemos considerar en la vanguardia temporal, que obedecian a criterios plásticos y constructivos de aquel periodo. El primero de ellos es ya inexistente al haberse demolido en enero de 2004. Se trata del antiguo Albergue de Automovilistas, construido hacia el año 1930, según el proyecto ganador del concurso convocado en 1927 con el fin de reproducirse por distintos puntos de la geografía española. Proyecto de los arquitectos Carlos Arniches y Martín Dominguez, que puede aún verse en Puerto Lumbreras, Bailén o 


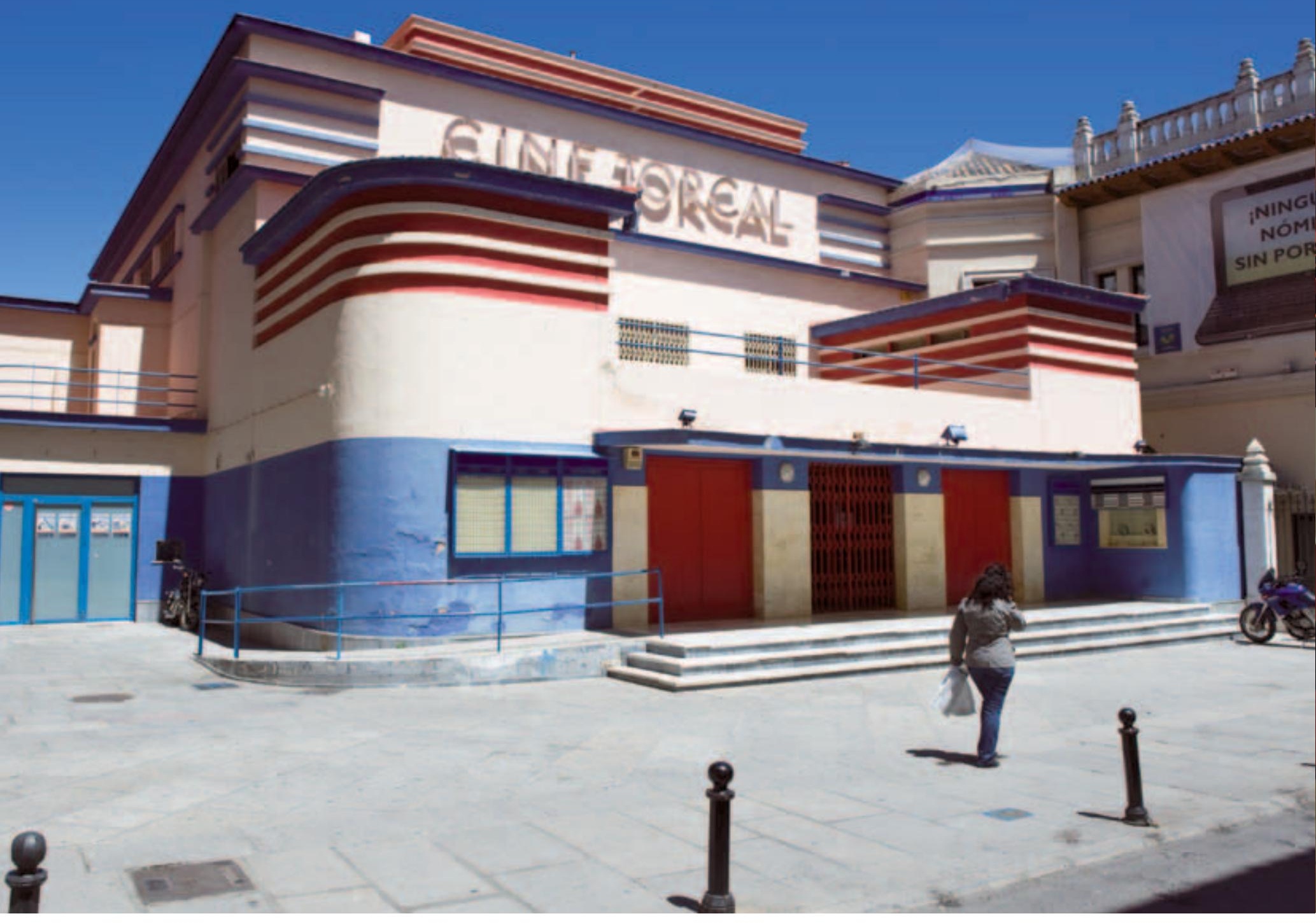

Entrada principal del Teatro Cine Torcal. Foto: Juan Carlos Cazalla, IAPH

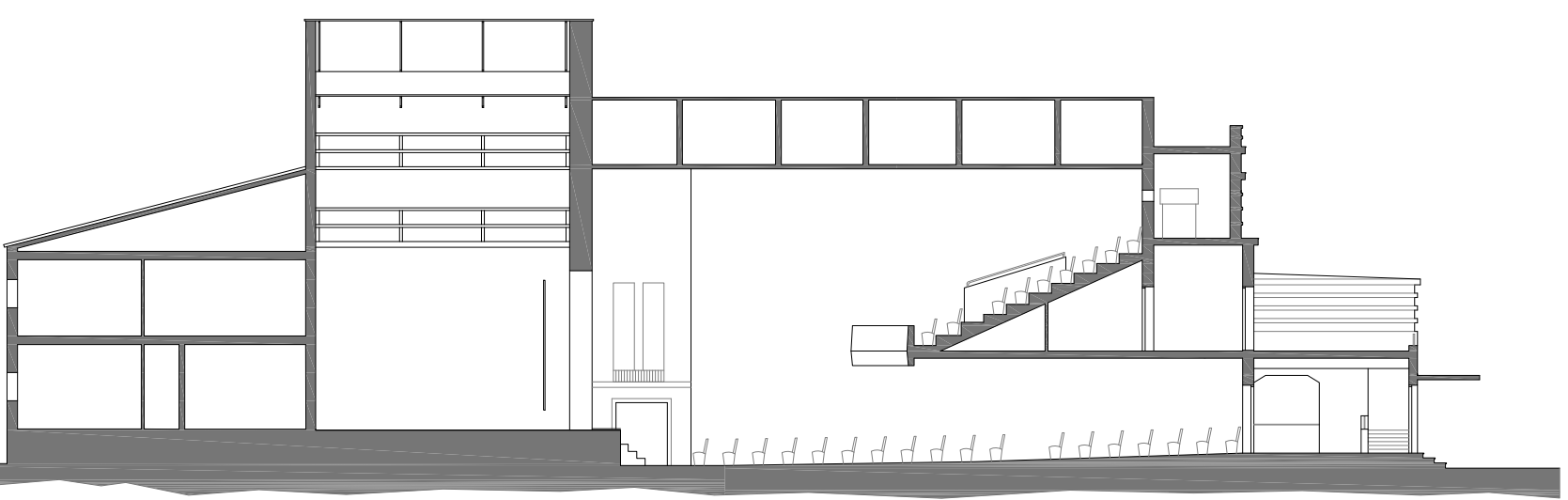




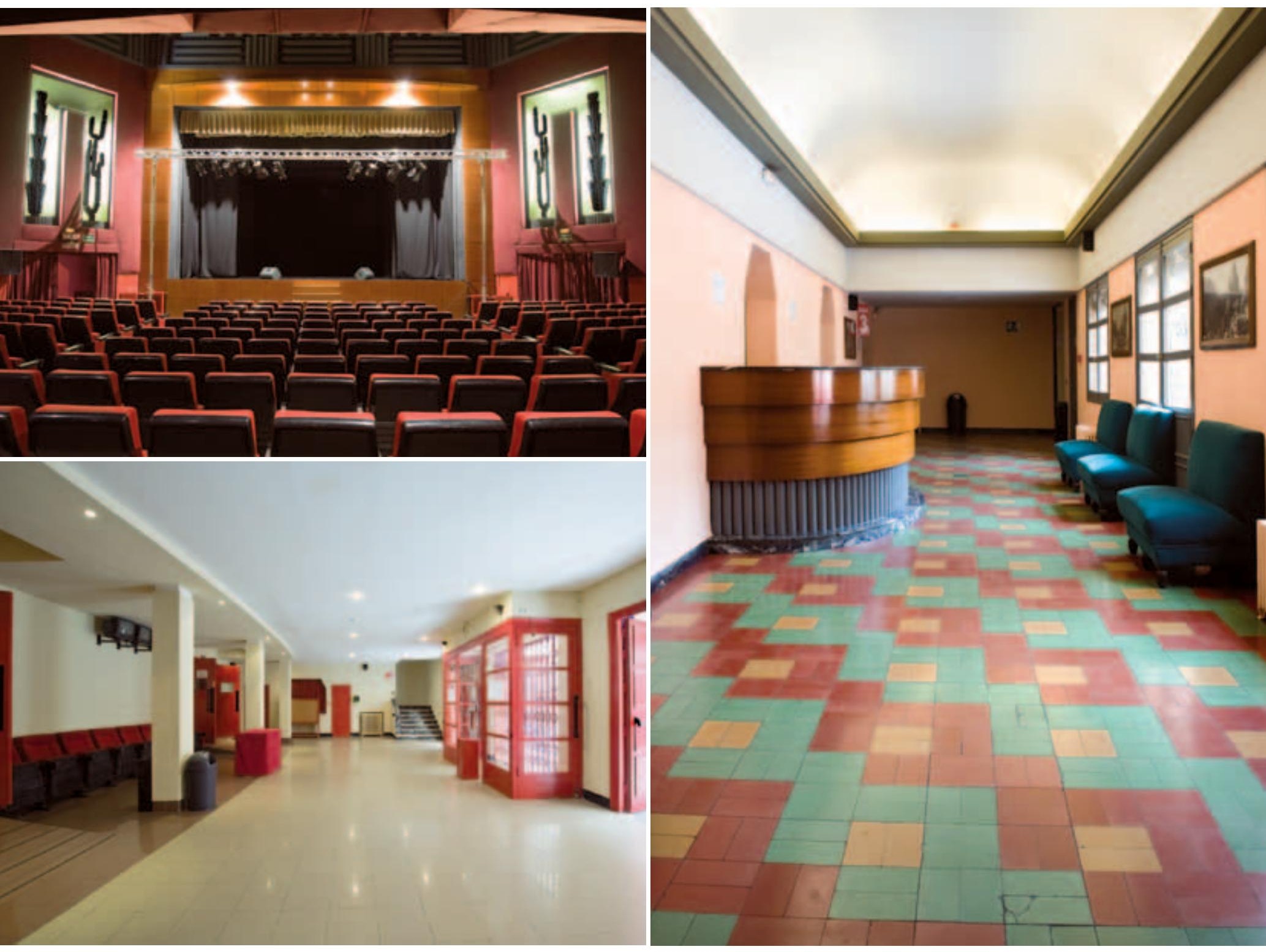

Sala y escenario del Teatro Cine Torcal (arriba), vestibulo de entrada (abajo) y zona ambigú (derecha). Fołos: Juan Carlos Cazalla, IAPH

Manzanares. Los otros dos edificios son el Teatro-Cine Torcal y la Antigua Biblioteca Antequerana. Aunque los promotores son locales, los arquitectos son foráneos y todos ellos llegaron a Antequera a instancia de sus mecenas.

En los primeros años 30 se encarga al arquitecto Daniel Rubio Sánchez el proyecto del edificio que debería ser la sede social de la Caja de Ahorros de Antequera; e, igualmente, al arquitecto Antonio Sánchez Esteve, el Teatro-Cine Torcal. En este último caso, su experiencia en modelos de edificios cinematográficos, ya que había proyectado y construido los cines Gades y Municipal de Cádiz (éste también teatro), fue probablemente la principal razón del encargo. La proximidad geográfica entre Antequera y Málaga, como residencia habitual de Daniel Rubio en aquellos momentos, haria posible y conveniente su participación en el proceso de las obras del Teatro-Cine Torcal. Antonio Sánchez Esteve construyó al siguiente año el Málaga-Cinema, otro edificio cinematográfico racionalista.
La sociedad anónima "Antequera Cinema" (LARA GARCIA, 2008) procura la construcción de un edificio público de carácter lúdico y cultural para la ciudad de importante trascendencia y características singulares. ¿Por qué se opta por un estilo racionalista en la construcción de este edificio cuando, en contraposición, se construye junto a él, por promotores que también participan de la entidad de la Caja de Ahorros, otro edificio muy singular de clara y diferenciada estética? Una dualidad en la que se enfrentan, nunca mejor dicho, lo ecléctico monumental, elementos manieristas, barrocos y neoclásicos (ROMERO BENITEZ, 1989), y por otro lado, la vanguardia más avanzada en ese momento en el país. Se explica probablemente por ser el cine, entonces, un fenómeno de masas para el ocio y la cultura, y requiere que su arquitectura contenedora sea igualmente espectacular y de fuerte imagen plástica. Recordemos el nacimiento del cine y los cines Odeón ingleses.

El Teatro-Cine Torcal se sitúa en una parcela del centro de la ciudad comunicado a tres calles. Se construyó con sentido uni- 
El periodo que abarca los

años entre 1925 a 1936,

momento del alzamiento

militar, fue sin lugar a

dudas una etapa definida

arquitectónicamente (...)

en Antequera, diferentes

edificios se construyen

obedeciendo a criterios

bien diferenciados

tario y completo. El acceso principal se realiza por su fachada sur a la calle Ramón y Cajal, la de mayor anchura, generando un retranqueo respecto a la alineación de los edificios colindantes contiguos y el resto de la calle, a fin de mejorar sus condiciones visuales y accesos. El frente del edificio marca un eje de simetría, a pesar de disponer de otra entrada lateral por su fachada oeste. Permite una doble comunicación en concordancia con los dos niveles que el edificio dispone: patio de butacas y anfiteatro. Doble acceso, doble taquilla y controles que posibilitan fluidez para un aforo inicial en torno a 890 localidades. Un vestíbulo previo al patio de butacas y dos escaleras, dispuestas simétricamente en cada uno de sus lados, conforman el primer y original espacio. En la planta alta, un segundo vestíbulo con ambigú reparte los accesos al anfiteatro. Desde este último se da salida a una amplia terraza al exterior, produciendo un retranqueo en la fachada principal; dos cuerpos salientes dispuestos simétricamente, abrazando la terraza, definen su volumetría. La tramoya, tras el escenario, alberga los camerinos y otras dependencias interiores de servicio.

Un interesantísimo juego de volúmenes escalonados, con esquinas redondeadas, tanto en el frente como laterales de sus fachadas, componen un conjunto de elevada riqueza plástica, potenciados por sus colores rojo y azul aplicados sobre los rehundidos y elementos salientes. La ausencia total de molduras y filigrana de cualquier tipo, decoraciones superfluas, concentra y define sus formas, potenciando el valor compositivo. En el interior, y solo aquí, se permite puntualmente acudir a elementos art-decó característicos, como son los yesos en forma de cactus de las hornacinas que se sitúan a ambos lados de la embocadura del escenario. Toda la iluminación es indirecta y aprovecha los foseados circulares de los falsos techos. Bandas horizontales en relieve recorren la zona superior de las paredes, unifican el espacio de la sala que acoge las dos áreas de anfiteatro y patio de butacas.

El edificio, tras su inauguración en enero de 1934, ha tenido diversas actuaciones de reforma, aunque todas han conservado el carácter y los elementos principales, no modificándose cuerpos o volúmenes singulares, y sin la pérdida de elementos decorativos. Los accesos, vestíbulos, huecos de paso y alguna soleria han permanecido inalterables. El edificio fue utilizado como discoteca y sala de fiestas en periodos que requirieron una adaptación por parte de la empresa en los momentos de la crisis cinematográfica, volviéndose posteriormente a su uso original. Hoy es multisala de cine; dos dispuestas en el anfiteatro, y una sala que casi no altera el original, el patio de butacas. Actualmente se viene utilizando para teatro y cine indistintamente al conservar la tramoya y los espacios primitivos. El estado general es aceptablemente bueno. Pasó a propiedad municipal el pasado año 2009 y actualmente se procede a la redacción de un proyecto para su rehabilitación, conservación y mejora del mismo ${ }^{1}$. El edificio está incluido en el catálogo de protección de Bienes Culturales, como Edificio de Interés, así como en el catálogo de edificios protegidos del PEPRI y el PGOU de Antequera; también forma parte del registro Do.Co.Mo.Mo. entre los Edificios de Equipamiento elaborado en $2009^{2}$.

El edificio referido anteriormente, la Antigua Biblioteca Antequerana, responde a una composición igualmente racionalista, cuyo proyecto y construcción se desarrolla en estos mismos años. En este caso, la autoria corresponde al arquitecto Daniel Rubio, que estaba, como ya se ha dicho, realizando en esas mismas fechas la construcción de la sede bancaria. La sociedad "Hidráulica Andaluza", que atendia, entre otras, las necesidades de alumbrado público una vez decidida la sustitución de aceite como combustible por el sistema eléctrico, promueve la construcción de un edificio que aloje oficinas y talleres de la compañia. En este caso, el edificio es mucho más modesto y de menores dimensiones; sin embargo, su localización, en la esquina entre las calles Ramón y Cajal y Herrezuelos, favorece su implantación y presencia urbana. Son tres las plantas con las que cuenta, rematadas con cubierta plana. El conjunto hoy existente se llevó a cabo en dos etapas, según un proyecto original de 1933 y una ampliación de 1934².

Los elementos que lo caracterizan son claramente racionalistas y en similitud con el lenguaje compositivo del Teatro-Cine Torcal que se sitúa a tan solo dos parcelas contiguas. Su fachada es lisa, salvo en la planta baja que incorpora pequeños rehundidos horizontales realizados con ladrillo cerámico aplantillado; otros sencillos elementos cerámicos enmarcan los huecos mediante un recercado; una moldura separadora entre plantas y el remate superior de fachada junto al arranque del pronunciado voladizo recoge el volumen principal del edificio donde también se dispone una franja de cerámica vidriada. Es un singular edificio que, a pesar de los años transcurridos y su fuerte implantación urbana, ha sido ignorado, no teniendo hasta el momento valoración arquitectónica alguna legalmente. Se espera que el documento del PGOU en tramitación lo incorporará al catálogo de edificios protegidos. El edificio se encuentra actualmente en obras, siendo adaptado a sala de exposiciones por la entidad bancaria propietaria. Ha sido incorporado en el registro Do.Co. Mo.Mo. Ibérico entre la relación de edificios de Equipamiento 


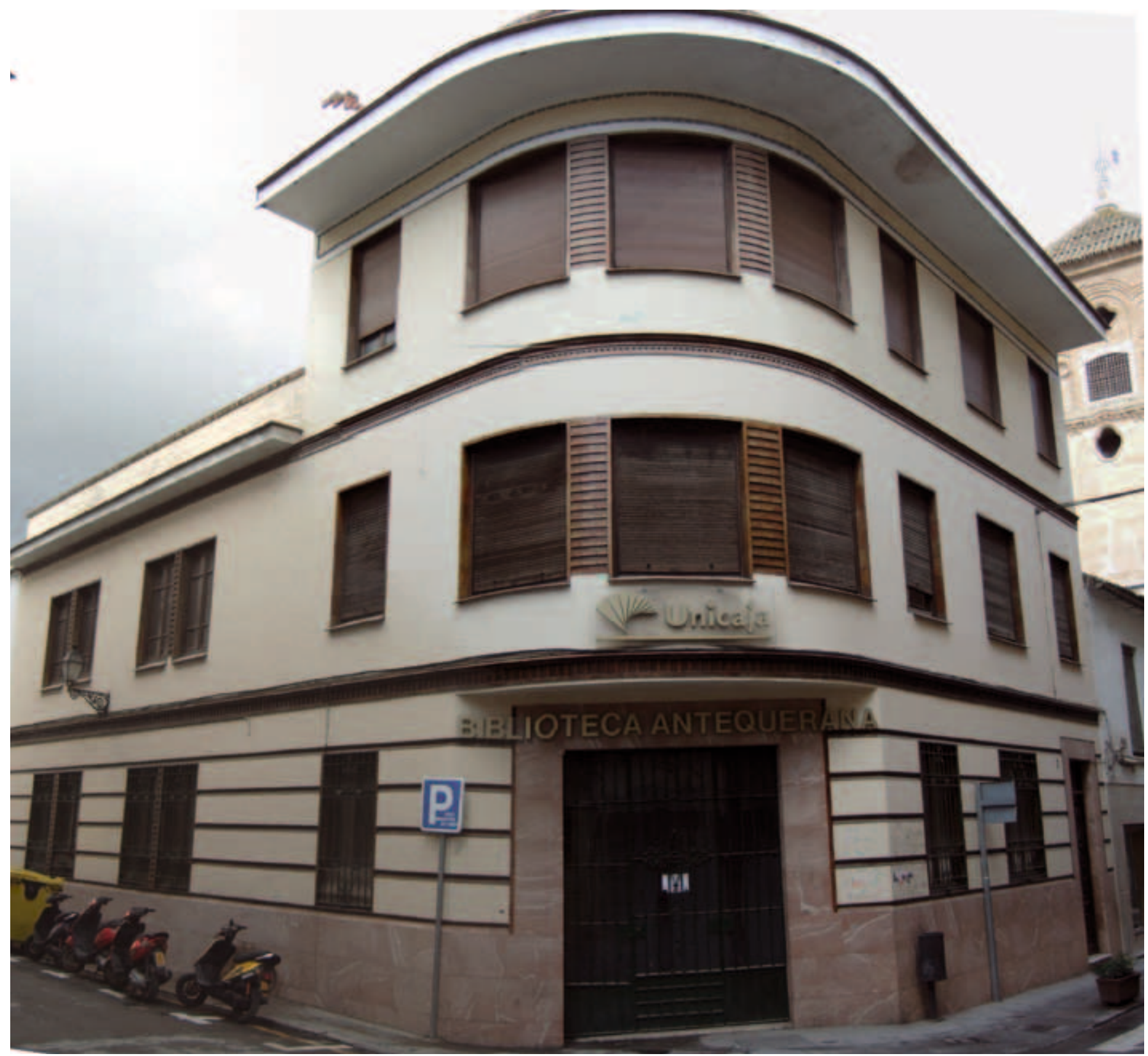

Fachada de la Antigua Biblioteca Antequerana. Foto: Sebastián del Pino Cabello

de la provincia de Málaga ${ }^{4}$ (FUENTES TORRES, 2008; FERNÁNDEZ PARADAS, 2006)

\section{ADENDA}

Puesto que venimos refiriéndonos a los valores con los que cuentan algunos de los edificios de esta ciudad, y por la falta de reconocimiento y su puesta en valor han sufrido el abandono y a veces la demolición, considero necesario referirme finalmente, aunque el periodo de su construcción no coincida en el tiempo, a otro singular ejemplo de arquitectura local. Esta situación me hace recordar los mismos efectos que sobre la valoración del TeatroCine Torcal se generaban en los inicios de los años 1980. Solo la difusión en la prensa local, el montaje de una exposición que mostraba planimetría expresamente elaborada por arquitectos de la localidad, hacía referencia a él y lo señalaban como edificio "a proteger". A partir de entonces se tomó general conocimiento y se iniciaron actuaciones por parte de la administración para su defensa patrimonial en los años siguientes. Actualmente, la Antigua Biblioteca Antequerana que aquí recogemos también se encuentra en similares condiciones de desprotección puesto que no hay oficialmente ningún documento que lo avale definitivamente.

El caso a que me refiero es el del Instituto Pedro Espinosa, un edificio contemporáneo cuyo proyecto se redacta en el año 1960, del arquitecto madrileño Antonio Galán Lechuga, situado en la calle Carrera, en el mismo centro de la ciudad. Éste había acudido a la ciudad para llevar a cabo una remodelación del Palacio de la Peña de los Enamorados para colegio de la comunidad religiosa carmelita y, posteriormente, la remodelación de la fachada principal del Ayuntamiento (en el año 1954). En la parcela colindante al primitivo instituto, siendo éste una casa-palacio, se construye un edificio lineal, compacto y único 


\section{El Archivo Municipal de Antequera}

Antequera conserva en su Archivo Histórico Municipal una singular colección documental formada tras largos años de una política encaminada a la recuperación de este patrimonio. El conjunto presenta 12 grandes fondos que aglutinan desde documentación municipal a protocolos, archivos cofrades, empresariales, familiares, eclesiásticos e incluso fotográficos. Y que responde al siguiente organigrama o cuadro de clasificación:

01. Fondo municipal.

02. Fondo de protocolos notariales.

03 . Fondo parroquial.

04. Fondo de hermandades y cofradias.

05. Fondo judicial.

06. Fondo de archivos familiares.

07. Fondo Real Colegiata.

08. Fondo hemeroteca.

09. Fondo videoteca y filmoteca.

10. Fondo fotográfico.

11. Fondo archivos de empresas.

12. Fondo Cámara Agraria.

En total en la actualidad se cuenta con algo más de 35.000 unidades de instalación, que contienen documentos en soportes de toda índole, algo un tanto inusual en centros de estas características, por lo que el archivo antequerano se convierte en un referente por su diversidad y por el tratamiento innovador que se está dando a esta masa documental.

Los documentos se han conservado casi siempre en las dependencias de la Casas Consistoriales, primero en su ubicación junto al Arco de los Gigantes, en la plaza de la Feria; posteriormente en la Casa de Cabildos de la Plaza de San Francisco, para ser trasladados, en la última mitad del siglo XIX, al nuevo Palacio Consistorial de los Remedios, donde permanecerán hasta constituir

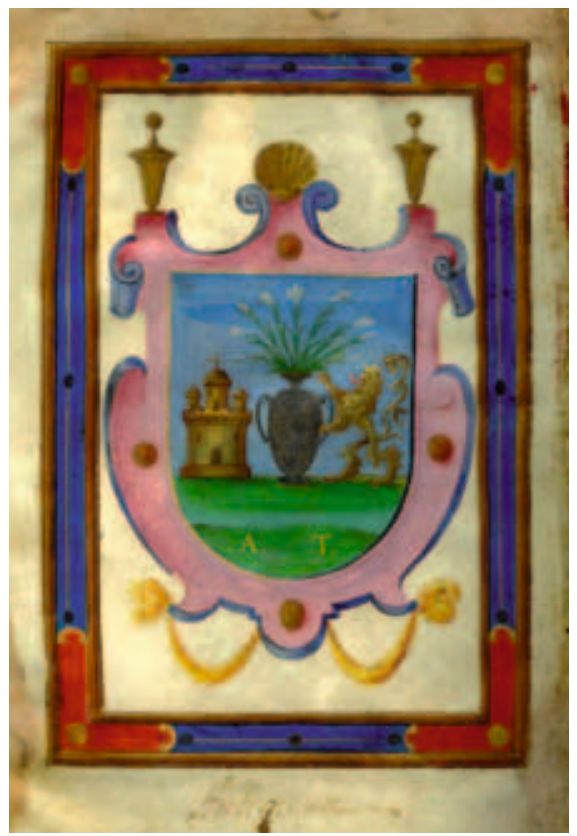

Escudo de Antequera en pergamino. Fuente: Archivo Municipal de Antequera. Real Carta de Merced confirmando las franquezas de la ciudad de Antequera, 1616 el Archivo Histórico Municipal de Antequera en 1970, siendo llevada la documentación al Palacio de Nájera, sede del Archivo y Museo, donde estará hasta 1995, fecha en la que pasa nuevamente toda la documentación al antiguo edificio del Pósito de la Ciudad, acondicionado especificamente para este fin.

En los últimos años se ha realizado una decidida apuesta por hacer del archivo de la ciudad un centro abierto y plural. Hay que destacar las numerosas actividades de difusión cultural y la incorporación plena de las nuevas tecnologías. Un ambicioso programa de gestión electrónica de documentos que se ve ahora culminado con el acceso a sus fondos documentales a través de Internet, además de contar con un taller de empleo como herramienta complementaria y a la vez formativa de especialistas en el tratamiento documental. Este taller, que se ha desarrollado en dos ocasiones bajo las denominaciones El Arca de la Memoria y Pósito de Memoria, ha consistido en una experiencia en la que se ha tratado de formar a personal especializado en las tareas de conservación y mantenimiento de un archivo. Tanto en uno como en otro se han impartido tres módulos formativos dedicados a la digitalización, documentación y restauración del material archivistico. Fruto de estos trabajos ha sido la espectacular actualización que nuestro centro ha sido capaz de asumir dando el tratamiento correcto a su masa documental. Se está planteando ya un tercer proyecto para continuar con este impulso; por un lado, para la creación de técnicos y, de otro, para mantener el equilibrio en el mantenimiento y oferta del archivo antequerano. Este proyecto nacerá bajo la denominación del Hilo de la Memoria.

El planteamiento inicial del centro, hace ya dos décadas, se basaba en establecer unas pautas encaminadas a la recuperación de un patrimonio documental del que se tenía conocimiento en la ciudad, si bien de carácter privado en muchos casos. La oferta pública ofrecia al propietario de la documentación la posibilidad de su conservación, digitalización y descripción en el Archivo de Antequera; a cambio el centro podria disponer libremente de este material y difundirlo bien a través de la Red, bien usándolo en las distintas formas de difusión y divulgación que estimara oportunas. El resultado pasado el tiempo ha sido realmente espectacular. En 1990 el Archivo de Antequera contenía tan sólo la documentación de carácter municipal, los protocolos notariales de su distrito y los archivos parroquiales. Fruto de esta política de recuperación ha sido posible tener hoy día 25 archivos de cofradias, 12 archivos familiares, 3 archivos de empresas, el archivo de la Antigua Cámara Agraria y 6 archivos fotográficos. Estos últimos de muy reciente incorporación y consistentes en el depósito de material analógico de distintos laboratorios fotográficos profesionales de la ciudad; en este sentido se han recuperado y forman parte del patrimonio documental de Antequera miles de clichés y placas fotográficas que reflejan la historia viva de la ciudad, en definitiva la historia del siglo $X X$, captada por los objetivos de distintas generacio- nes de fotógrafos locales. Posiblemente esta aportación sea la más espectacular que ha realizado nuestro archivo, tanto por la información que aporta de un periodo, como por los soportes especiales, que necesitan un trato muy especifico y unas condiciones de uso y conservación distintas al papel.

El planteamiento de un archivo local que recogiera de una forma global la distinta documentación de instituciones y personas para su conservación y uso público es hoy dia ya una realidad, y el esfuerzo realizado se ve compensado con las aportaciones que constantemente van engrosando el patrimonio de la ciudad, prueba inequivoca de la confianza que se está prestando a nuestro proyecto, avalada por los resultados obtenidos.

El fin de todo este proyecto y esfuerzo es, en definitiva, por un lado, recuperar el rico y variado patrimonio documental de la ciudad de la manera más completa posible y ofertar un espacio para su conservación. Tradicionalmente muchos archivos en nuestra comunidad han acabado vendidos al peso, en papeleras, tirados o mal vendidos a especuladores, con lo que se ha perdido parte de nuestra historia. Por otro lado, no tendría sentido alguno acumular esta masa documental sin darle una difusión adecuada; el uso de las nuevas tecnologias nos brinda la posibilidad, hace años impensable, de contar con una serie de herramientas fundamentales que nos están permitiendo llevar a cualquier parte del mundo los contenidos de nuestro archivo con unos resultados satisfactorios. Se trata de hacer uso común y ampliar al máximo la tipología de usuarios que generalmente tienen acceso a la información de los archivos, un público que hemos comprobado cada vez es más variado. El acceso a la información se hace por el portal institucional del Ayuntamiento de Antequera http://www.antequera.es, que nos da paso a la página del archivo, elemento de presentación de nuestro trabajos y que ofrece el acceso a la información y a la documentación a través de una base de datos relacional, que permite obtener información y visualizar objetos multimedia que reproducen una gran variedad de documentos. Podemos destacar, en este sentido, el acceso en formato pdf. a las actas capitulares de la ciudad desde el siglo XV al primer cuarto del siglo XX, o a la colección de carteles taurinos, o a una hasta ahora escogida selección de imágenes fotográficas, entre los casi más de un millón y medio de imágenes que son accesibles por la Red. La gran mayoría de los documentos están en ese formato universal que antes hemos indicado. En el propio archivo se puede acceder por medio de la red interna a casi el doble de documentos digitalizados, ya que en la actualidad solamente una parte está disponible en abierto. Los proyectos desarrollados y en los que se está trabajando muestran un archivo con grandes ambiciones, y con una tremenda preocupación por la recuperación y difusión del patrimonio documental.

José Escalante Jiménez

Director del Archivo Municipal de Antequera 


\section{El Catálogo General del Patrimonio Histórico Andaluz en la vega de Antequera y Archidona}

De los 15 municipios que dibujan el territorio que conforma la vega de Antequera y Archidona, 12 están afectados en su totalidad y tres parcialmente.

Los 43 bienes patrimoniales que se encuentran en esta vega pertenecen la mayoría al municipio de Antequera (28), hecho que se explica por dos motivos principales: la amplitud territorial y la importancia que tuvo y ha tenido dicho municipio a lo largo de la historia, gracias a su situación estratégica como vía de comunicación entre la alta y la baja Andalucía.

Si clasificamos los 43 bienes por la figura legal que les da protección, nos encontramos que la gran mayoría (41) son Bienes de Interés Cultural (BIC), frente a los dos de Catalogación General. De los BIC, la tipología jurídica que destaca es la de Monumento (23), seguida por la Zona Arqueológica (16) y, por último, los Conjuntos Históricos de Antequera y Archidona.

En los últimos dieciocho meses el Servicio de Protección del Patrimonio Histórico de la Dirección General de Bienes Culturales ha propiciado, en este territorio, la protección de varias zonas arqueológicas, testigos del poblamiento desde época prehistórica.

Uno de los expedientes más destacable en la vega de Antequera y Archidona es el denominado Ámbito arqueológico de los Dólmenes de Antequera, inscrito en el Catálogo General del Patrimonio Histórico Andaluz (CGPHA) como Bien de Interés Cultural, tipología
Zona Arqueológica, el 27 de enero de 2009, y el cual extiende su protección a un territorio donde coexisten cinco bienes diacrónicos y de diferente naturaleza, que comparten un paisaje y un entorno común: Dolmen de Menga, Dolmen de Viera, Dolmen de El Romeral, yacimiento del Cerro Marimacho o Cerro de Antequera, y yacimiento de Carnicería de los Moros o Villa romana de Antequera.

Desde el punto de vista de la protección, los tres dólmenes tuvieron su reconocimiento como bienes patrimoniales ya desde el siglo XIX. La Cueva de Menga fue a través de la Real Orden de 1 de junio de 1886 que la declaró Monumento Nacional. Posteriormente se ratifica mediante Real Decreto de 12 de julio de 1923 en la que se reconoce también la importancia de la Cueva Chica o de los Hermanos Viera. Años más tarde, en 1931, se declara con el mismo carácter la Cueva de El Romeral.

Con fecha 17 de marzo de 2009, se inscribe en el CGPHA como Bien de Interés Cultural, Zona Arqueológica, un poblado ibero claramente romanizado, El Cerro de los Castillones (Campillos). Se trata de uno de los asentamientos paradigmáticos de los cambios en la organización de las sociedades prerromanas.

Más tarde, con fecha de 1 de diciembre de 2009, se protegió como BIC Zona Arqueológica el yacimiento denominado Las Capacheras (Archidona, Málaga), asentamiento fortificado u "oppidum", que cierra las defensas de época ibérica por el noreste de la provincia de Málaga.

Por último, el Decreto 63/2010, de 16 de marzo, inscribe en el Catálogo General del Patrimonio Histórico de Andalucía como Bien de Interés Cultural, tipología Zona Arqueológica, la Necrópolis protohistórica de la Noria, en el término municipal de Fuente de Piedra. Esta necrópolis se desarrolla en dos grandes periodos cronológicos, periodo protohistórico y periodo romano, con diferentes tipos de enterramientos.

Con estas actuaciones administrativas se ha querido distinguir la vega de Antequera y Archidona como un territorio de gran interés para el conocimiento de la prehistoria y protohistoria en Andalucia, importancia arqueológica que se une al sustancial legado arquitectónico de los siglos XVI al XVIII patente en la comarca.

El Catálogo General del Patrimonio Histórico Andaluz está abierto a la consulta pública en la página web de la Consejería de Cultura, dentro del área de Bienes Culturales: http://www.juntadeandalucia.es/cultura

Olga Viñuales Meléndez Alfonso Montejo Ráez Servicio de Protección del Patrimonio Histórico Dirección General de Bienes Culturales

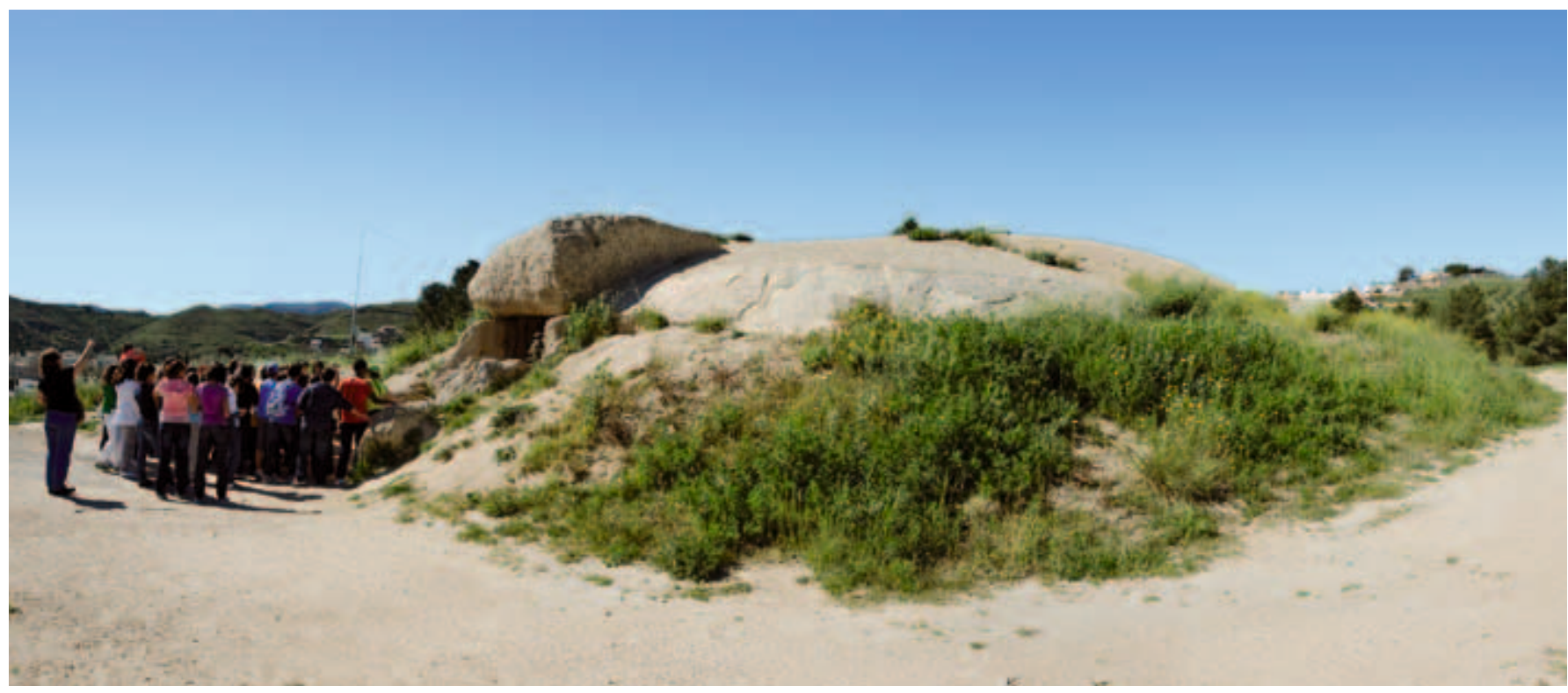



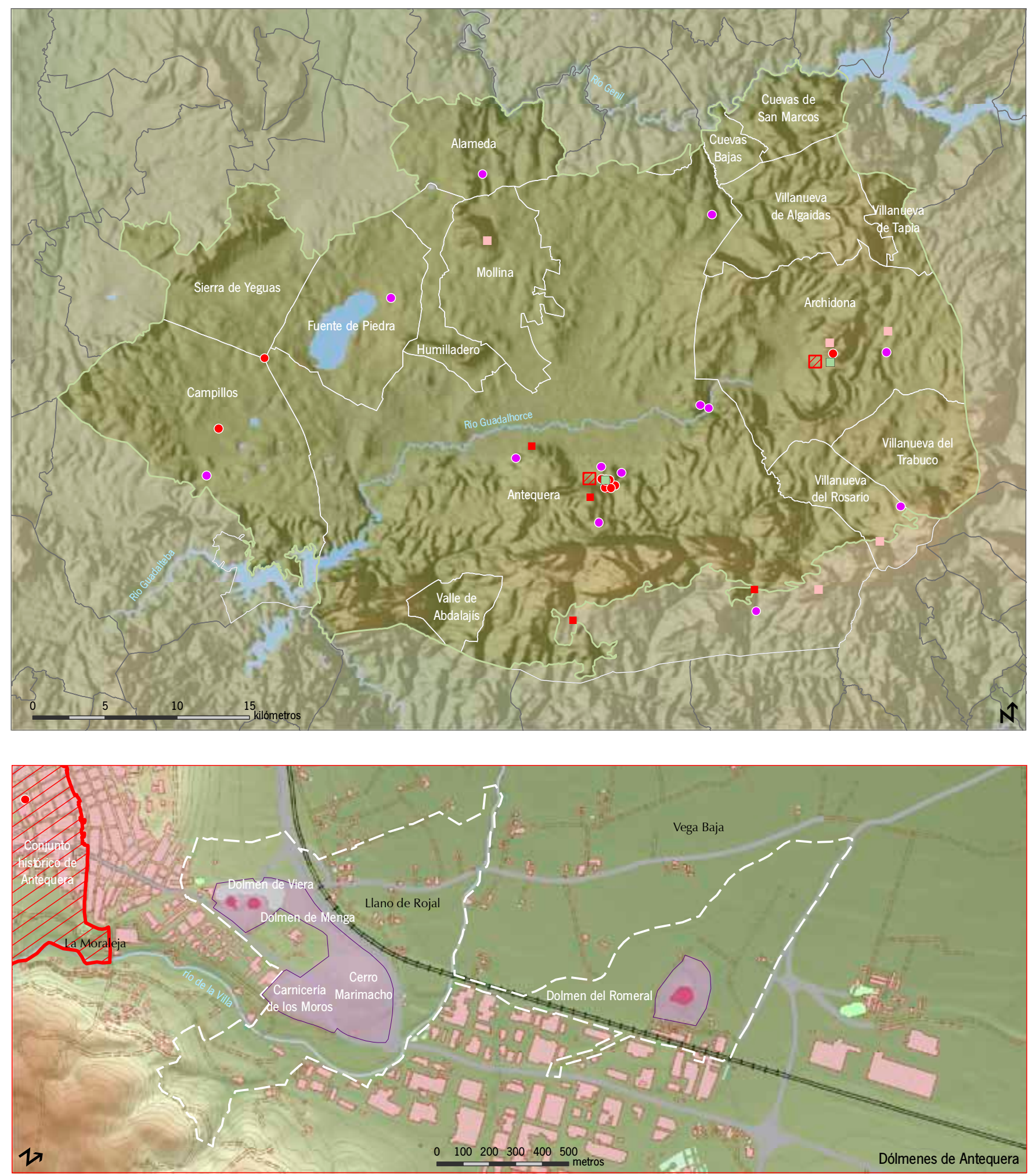

\begin{tabular}{|c|c|c|}
\hline $\begin{array}{l}\text { Bien de Interés } \\
\text { Cultural }\end{array}$ & $\begin{array}{l}\text { Monumento } \\
\text { Arquitectura militar }\end{array}$ & $\begin{array}{l}\square \quad \text { Conjunto Histórico } \\
\text { - Zona Arqueológica }\end{array}$ \\
\hline & Arte rupestre & Entorno \\
\hline
\end{tabular}

Bien de Catalogación General
El Catálogo General del Patrimonio Histórico Andaluz en las Vegas de Antequera y Archidona

Cartografia base: Datos Espaciales de Andalucia 1:100.000 (2009), Modelo Digital del Terreno de Andalucia (2005), y Mapa Topográfico de Andalucia 1:10.000 vectorial (2002), Instituto de Cartografía de Andalucía 


\section{Datos de base de la vega de Antequera y Archidona}

La zona de la vega de Antequera y Archidona' comprende quince municipios de la provincia de Málaga completos y tres municipios integrados parcialmente. Los municipios que se integran completamente en la zona estudiada son los siguientes: Alameda, Archidona, Cuevas Bajas, Cuevas de San Marcos, Fuente de Piedra, Humilladero, Mollina, Sierra de Yeguas, Valle de Abdalajis, Villanueva de Algaidas, Villanueva del Trabuco y Villanueva de Tapia. Parcialmente se integran los municipios de Antequera, Campillos y Villanueva del Rosario. El total de inmuebles que se localizan en esta zona son 334 de los cuales el $78 \%$ corresponde al patrimonio arqueológico, el 14\% al patrimonio arquitectónico y el $8 \%$ al patrimonio etnológico.

El patrimonio arqueológico localizado en la zona es muy abundante, pues los primeros asentamientos datan del paleolítico medio, aunque es en la Edad del Cobre cuando se producen grandes manifestaciones megalíticas como La Zona Arqueológica de los Dólmenes de Antequera, formada por los dólmenes de Menga, Viera y El Romeral, así como por una serie de yacimientos directamente relacionados con esta necrópolis. Muy próximo a los dólmenes se encuentra el asentamiento del Cerro de Antequera, que es un poblado calcolítico de la etapa campaniforme.

En la época romana se observa que el número de entidades arqueológicas casi se quintuplica con respecto a la prehistoria reciente, debido al intenso proceso de romanización que experimentó todo el territorio andaluz. Entre otros se encuentran la villa romana de La Estación, las Termas de Santa Maria, El Gallumbar, el poblado y necrópolis tardorromana de La Angostura y la ciudad romana de Singilia Barba.
En cuanto al patrimonio arquitectónico se encuentran en esta zona los centros históricos de Antequera y Archidona, declarados BIC como Conjuntos Históricos. Antequera tiene un esplendoroso pasado y se refleja en su patrimonio arquitectónico. Nos encontramos que la mayor parte del patrimonio arquitectónico pertenece a la Edad Moderna, como la Real Colegiata de Santa María La Mayor, primer templo concebido dentro del estilo renacentista de Andalucía y la Real Colegiata de San Sebastián, o el Monasterio de San Zoilo, así como numerosas iglesias y capillas. Es el siglo XVIII cuando la ciudad alcanza su máximo auge; se asientan varias congregaciones religiosas y se construyen numerosos conventos. También la nobleza erige grandes palacios y surge una gran actividad artística. Entre los conventos destacan el de Madre de Dios de Monteagudo, el Convento de San Agustín y el de San José; y, entre los palacios, el de la Marquesa de las Escalonias y el del Marqués de Villadarias.

En el centro histórico de Archidona destacan el CastiIlo y la Puerta del Sol, la Ermita de la Virgen de Gracia y la Plaza Ochavada, de gran belleza arquitectónica.

En cuanto al patrimonio etnológico nos encontramos numerosos edificios agropecuarios repartidos por la vega, dedicados a la producción de cereales y aceite así como varios molinos y almazaras vinculados a estos.

Desde el punto de vista de las tipologías funcionales y los periodos históricos a los que se asocia el patrimonio inmueble de la zona estudiada, se han utilizado los términos del Tesauro de Patrimonio Histórico Andaluz agrupándolos de la siguiente manera:
- Edificaciones productivas; los inmuebles pertenecientes a esta tipología suponen un $53 \%$ del total. - Edificaciones dotacionales, que agrupa distintas tipologias como las construcciones funerarias, sanitarias, de espectáculo, etc. Los inmuebles pertenecientes a esta tipología suponen un $6 \%$ del total.

- Asentamientos y espacios libres; los inmuebles pertenecientes a esta tipología suponen un 17\% del total. - Edificaciones militares; los inmuebles pertenecientes a esta tipología suponen un 6\% del total.

- Edificaciones religiosas; los inmuebles pertenecientes a esta tipología suponen un 12\% del total.

- Edificaciones residenciales; los inmuebles pertenecientes a esta tipología suponen un 4\% del total.

- Sitios con representaciones rupestres; los inmuebles pertenecientes a esta tipología suponen un 1\% del total.

En cuanto a los periodos históricos destacan la Época Romana, con 192 inmuebles, seguidos de la Edad Moderna, con 48 inmuebles, la Prehistoria Reciente, con 40 inmuebles, la Edad Media, con 29 inmuebles, la Protohistoria, con 17, la Edad Contemporánea, con 11 inmuebles y, por último, el Paleolítico, con 10 inmuebles.

Pilar Mondéjar Fernández de Quincoces Salud Soro Cañas

Centro de Documentación y Estudios del IAPH

\section{Nota}

'La información de carácter patrimonial contenida en el Sistema de Información para la Gestión Integral del Patrimonio Cultural relativa a la zona de la vega de Antequera y Archidona se analizará en base al patrimonio inmueble que se haya localizado cartográficamente en la misma.

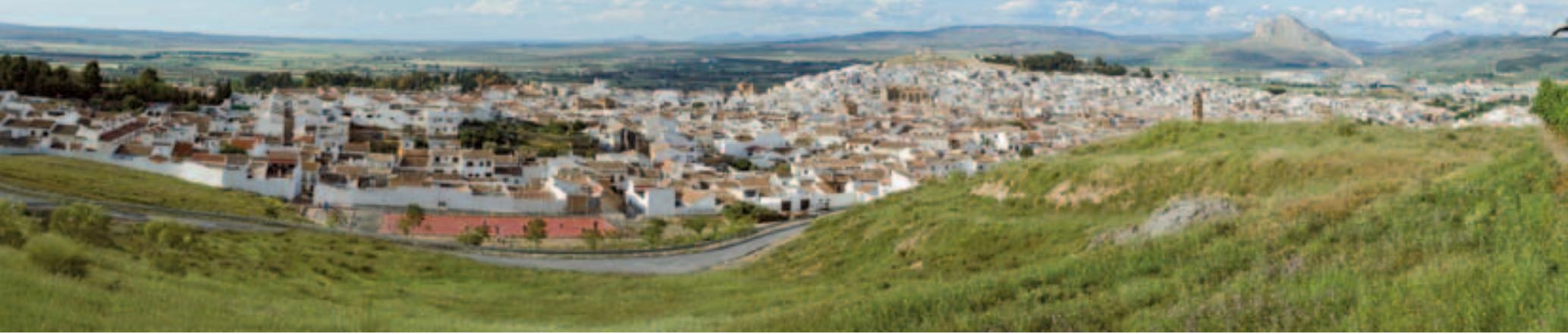

Panorámica de Antequera con la vega y la Peña de los Enamorados al fondo. Foto: Juan Carlos Cazalla, IAPH 


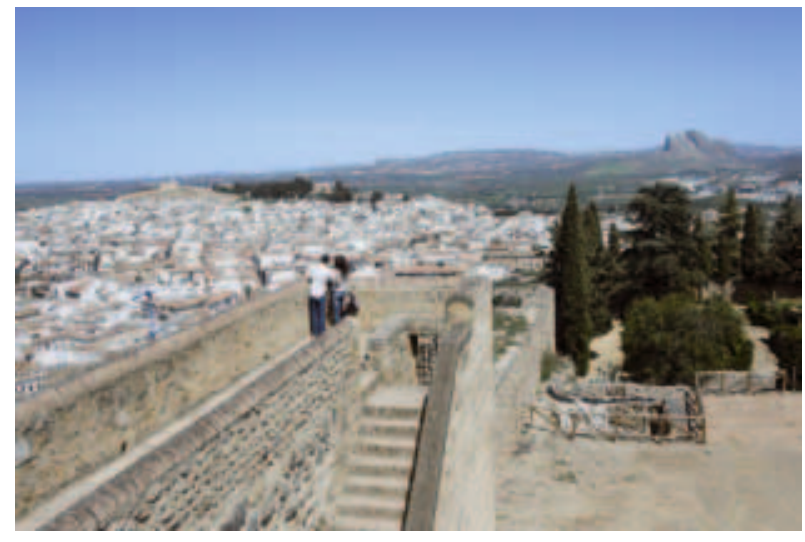

Alcazaba de Antequera. Foto: Juan Carlos Cazalla, IAPH

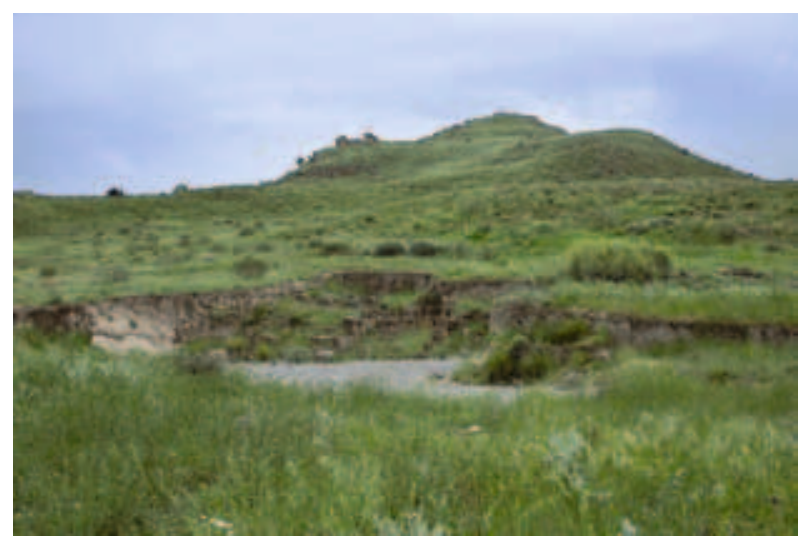

Singilia Barba. Foto: Juan Carlos Cazalla, IAPH
Gráfico 1. Distribución de inmuebles por Tipo de Patrimonio

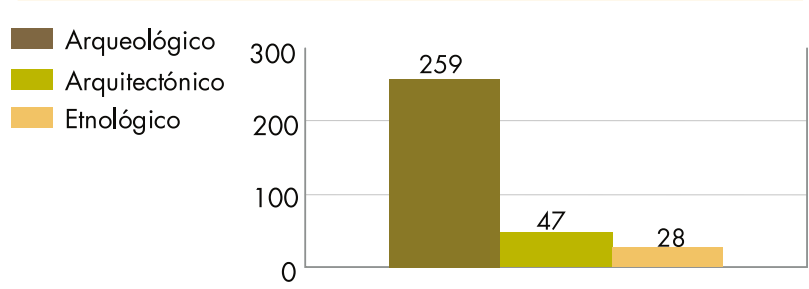

Gráfico 2. Distribución de inmuebles por Tipologías Funcionales
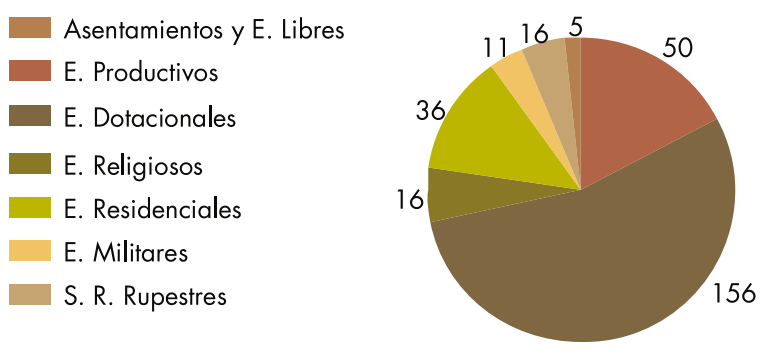

Gráfico 3. Distribución de inmuebles por Periodo Histórico

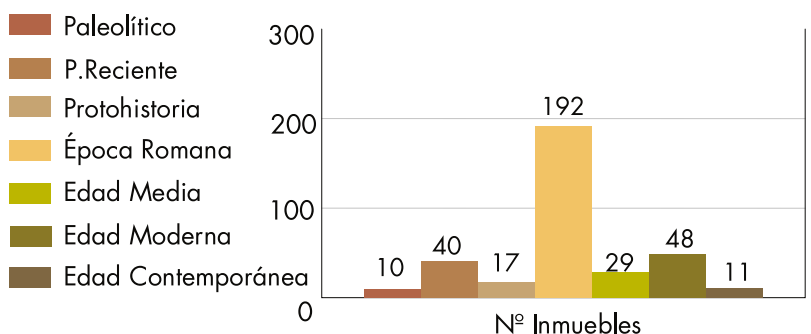

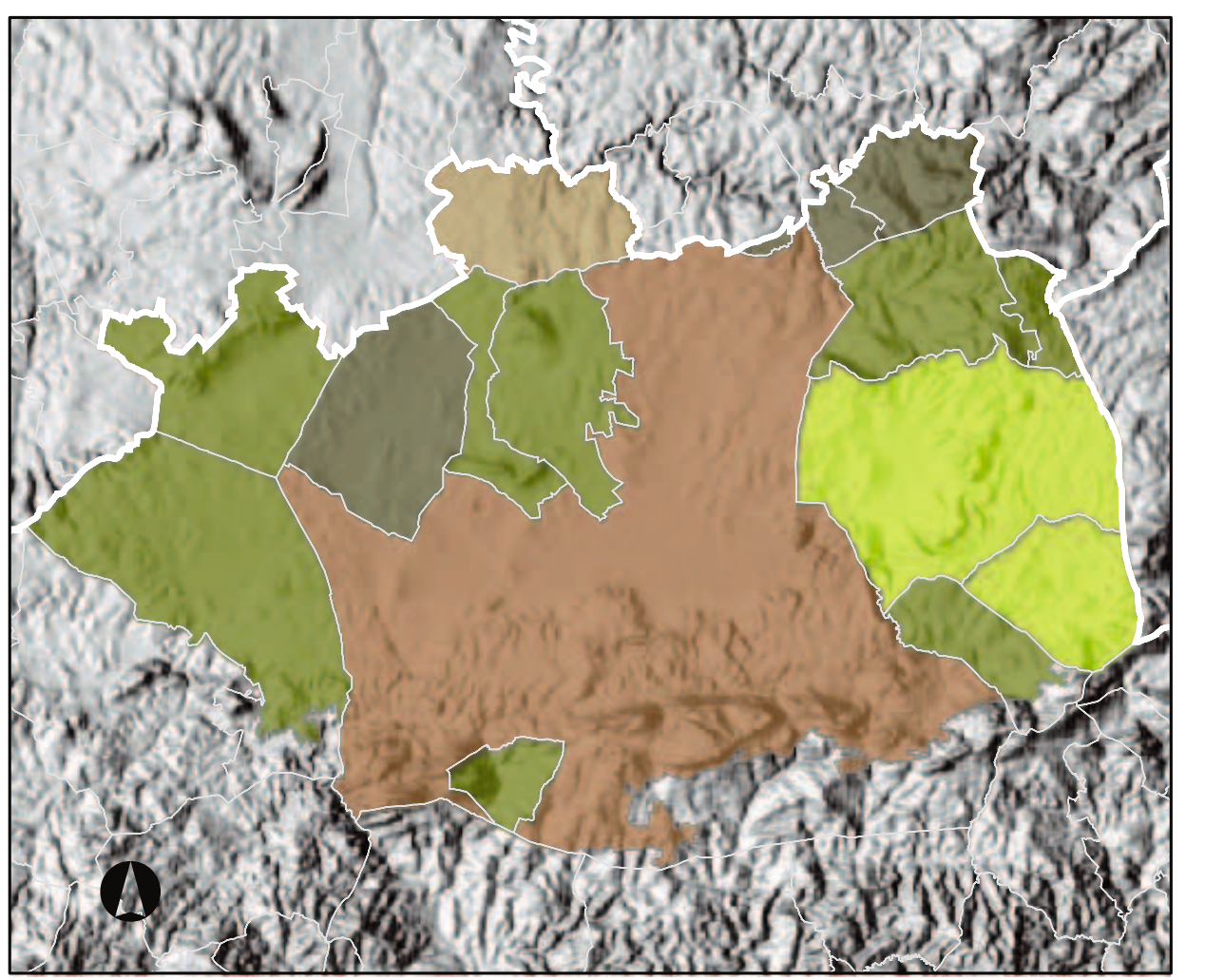

Mapa de distribución del Patrimonio Inmueble.

Antequera y Archidona

Leyenda

Municipios
Límites Provinciales

№ de Inmuebles

$0-3$

$4-14$

$15-36$

$37-77$

$78-133$

\section{Escala 1:500.000}

Proyección UTM USO 30

Localización del área

Antequera y Archidona. Distribución del Patrimonio Inmueble. Mapa y gráficos: Centro de Documentación y Estudios.IAPH

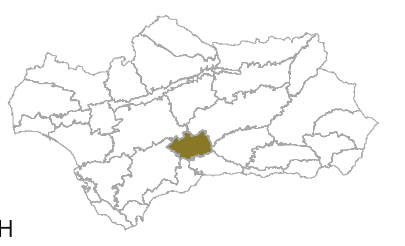




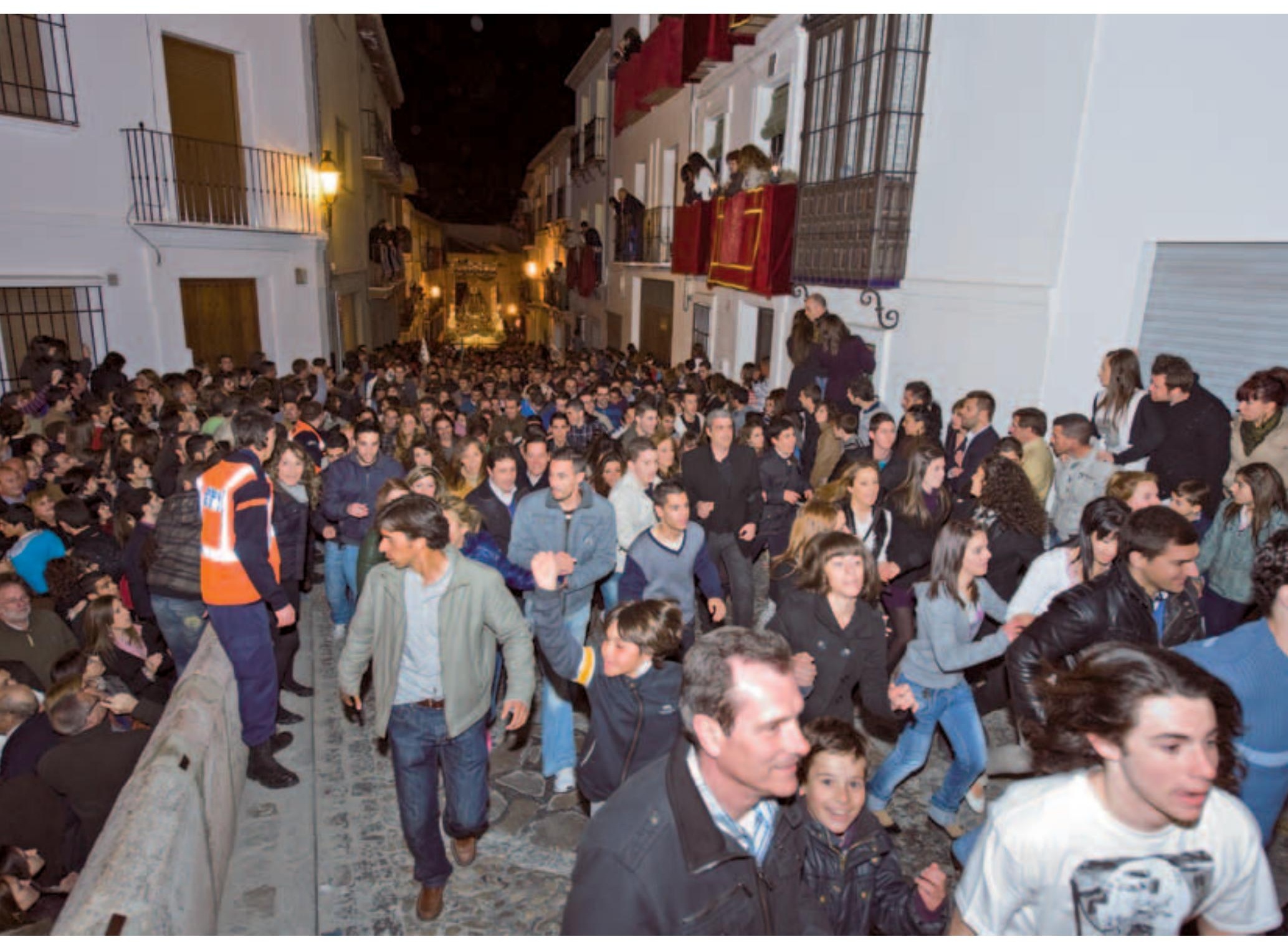

El trono de la Virgen del Socorro (hermandad de Arriba) y la multitud que lo precede corren su vega. Foto: Juan Carlos Cazalla, IAPH 


\section{Correr la vega. Dicotomías sociales y ritual en la Semana Santa de Antequera}

Isidoro Moreno Navarro, Grupo de Investigación GEISA, Dpto. de Antropología Social, U. de Sevilla

En numerosas ciudades y pueblos andaluces, la Semana Santa, más allá de su explícita dimensión religiosa, constituye un "hecho social total", tal como definió esta categoría, hace ya casi un siglo, el antropólogo francés Marcel Mauss (MORENO NAVARRO, 2008). Entonces, reflejando directamente la estructura social local de la sociedad que la celebra o, a veces, invirtiendo o incluso negando ésta en algunas o muchas de sus facetas (MORENO NAVARRO, 1999; 2006a), todas las dimensiones de la vida social -simbólica, identitaria, política, económica...- intervienen o se ven afectadas por la Semana Santa y todos, o la gran mayoría, de los grupos sociales participan, de una manera u otra, en este fenómeno sociocultural o, al menos, se definen o sitúan explícitamente respecto a él. Casi nada y casi nadie permanece ajeno o indiferente al mismo.

Es ésta una de las razones principales de que en Andalucia, contrariamente a lo que ocurre en la mayor parte de las regiones mediterráneas, incluido el Estado Español, la Semana Santa continúe siendo, en la época de la glocalización (MORENO NAVARRO, 2010), uno de los referentes de la identidad cultural (MORENO NAVARRO, 2000a; 2000b). Pocos lugares como Antequera donde esta afirmación esté más respaldada. La historia antequerana, desde casi el momento mismo de la conquista castellana hasta hoy, se ha reflejado en su Semana Santa. Y puede ser entendida a través del análisis de ésta, tanto en sus continuidades como en sus cambios (MORENO NAVARRO; TÁVORA, 1989).

La sociedad antequerana, tras la conquista y recristianización, se construyó sobre un doble dualismo. Por una parte, familias nobles grandes propietarias de feraces tierras, que constituian la base de su poder económico y social, monopolizando los cargos claves del poder municipal, y un alto número de trabajadores, sin tierras o con muy pocas y sin ningún poder, al servicio de estos. Sólo en un periodo, ya del siglo XIX, en que proliferaron las industrias textiles, se complejizó dicha dicotomía o fractura social, que sigue reflejándose en el urbanismo de la ciudad y en sus edificios. Pocas agrociudades como Antequera con más alta concentración de iglesias, conventos y palacios que contrastan con las modestas y blanquísimas casas del común de los vecinos.
Esta dicotomía de clases se tradujo, en los rituales y protagonismos de la Semana Santa, en elementos e incluso términos muy significativos y singularmente antequeranos. Por una parte, los hermanos mayores de insignia, con túnicas de terciopelo ricamente bordadas y la cara descubierta, con todo el poder sobre los tronos en los que desfilan las imágenes emblemáticas, y los campanilleros de lujo -niños con túnicas de larga cola bordada, que arrastra, y joyas en su cabeza-. Unos y otros pertenecientes a las más importantes familias. Por otra, los hermanacos, portadores de los pesados tronos llevando las horquillas con que se ayudan para descansar en las paradas y utilizan como palanca para tomar impulso en el trabajoso discurrir por las cuestas urbanas. A aquellos les corresponde el mando; a estos la obediencia. Se repite en cada cofradía y se visibiliza en sus procesiones la estructura de poder y subalternidad que regía la sociedad local en todos los ámbitos hasta la quiebra de las bases económicas de dicha estructura, en los años sesenta del siglo XX.

Pero no ha sido este dualismo -propietarios aristócratas versus campesinos sin tierra o con escasa propiedad-, traducido en hermanos mayores versus hermanacos en los rituales semanasanteros, el único presente en el devenir histórico de los casi seiscientos últimos años de una población varias veces milenaria. También, hasta entrado el siglo XX, persistió otra dicotomía: la existente entre dos conjuntos de familias poderosas enfrentadas permanentemente, que proyectaban su rivalidad en todas las facetas de la vida social incluyendo, de forma muy principal, el ámbito religioso y ritual, arrastrando tras ellos a sus respectivas clientelas y sectores dependientes. Encabezados por Chacones y Narváez, que fueron los dos linajes principales de la ciudad desde su toma por el Infante don Fernando en 1410, todos cuantos poseían parcelas de poder se agruparon en uno y otro bando, que impulsó y protegió a concretas órdenes religiosas, a su vez en rivalidad-especialmente dominicos y franciscanos-, y a las cofradias patrocinadas por éstas, las de "Arriba" y "Abajo", enfrentadas desde su misma fundación a finales del siglo XVI.

Estas dos dicotomías fueron los dos ejes, imbricados, a partir de los cuales se desarrolló la sociedad local y se constituyó su Sema- 


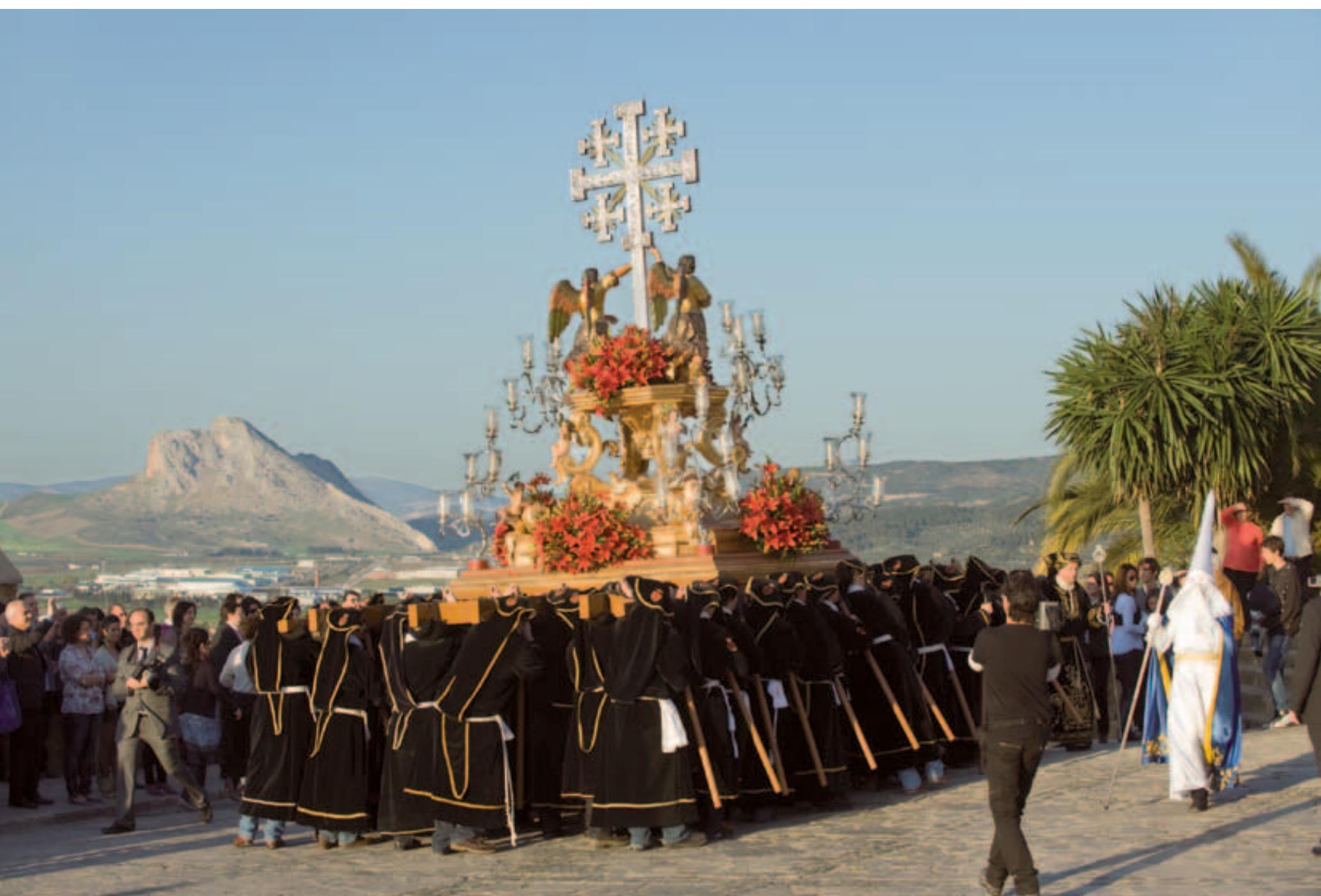

Trono de la Santa Cruz en Jerusalén, de la hermandad de Arriba, a poco de salir, sobre los campos y con la Peña de los Enamorados al fondo. Foto: Juan Carlos Cazalla, IAPH

con dieciséis varales o barras y otro, el de la Paz, que lleva doce agrupados en las cuatro esquinas. Y se ha recuperado el palio para un trono de Cristo, el del Nazareno de la Sangre de la hermandad de los Estudiantes...

También destacan, como momentos de alta emocionalidad, los Encuentros de los tronos de las dos cofradías del jueves y de la de Arriba y la de Abajo, el viernes. En el primer caso, se trata de la cofradía del Consuelo, de la parroquia de San Pedro, con la Virgen de este nombre -que va en el trono que pasa por ser el que más responde al "modelo sevillano"- y el Cristo de la Misericordia, y de la cofradia Servita del convento de Belén, con el Cristo amarrado a la columna, el Nazareno del Consuelo y la Virgen de los Dolores. Y el viernes se encuentran los cuatro tronos de la hermandad de Abajo con los tres de la de Arriba, en la plaza de San Sebastián.

Son estas cuatro hermandades las que "corren vegas". Correr la vega es, sin duda alguna, el elemento que más identifica y singulariza a la Semana Santa de Antequera. Quienes están presentes por primera vez pueden tener la sensación de asistir a una especie de sanfermines a lo divino: Ios tronos, llevados casi en volandas por los hermanacos, ayudándose de sus horquillas que golpean con fuerza el suelo, suben a la carrera empinadas cuestas para llegar al entorno de sus templos mientras una multitud los precede, también corriendo, a la vez abriendo paso y dificultando la subida. Para la carrera, el hermano mayor de insignia se despoja de sus pesados terciopelos, los hermanacos ajustan sus ropas y calzado, los músicos o piquetes militares interpretan marchas ligeras y tratan de despejar el camino. Se ponen en tensión todas las fuerzas. Durante las "vegas" se rompe el dualismo hermano mayor-hermanacos y se establece otra nueva polarización: la de cada trono, con hermanacos y hermanos mayores en gran medida fundidos, y el pueblo anónimo. Y todos corren, delante de la imagen.

Hacen vegas las dos cofradías del jueves, tras su encuentro: el Consuelo en la Cruz Blanca; la de los Dolores en la cuesta de Archidona, en los Cerrillos. Y también, el viernes, tras el suyo, la de Abajo por la cuesta de la Paz y la de Arriba por las cuestas de Zapateros, Viento y Herradores, hasta el Portichuelo. Como suele 


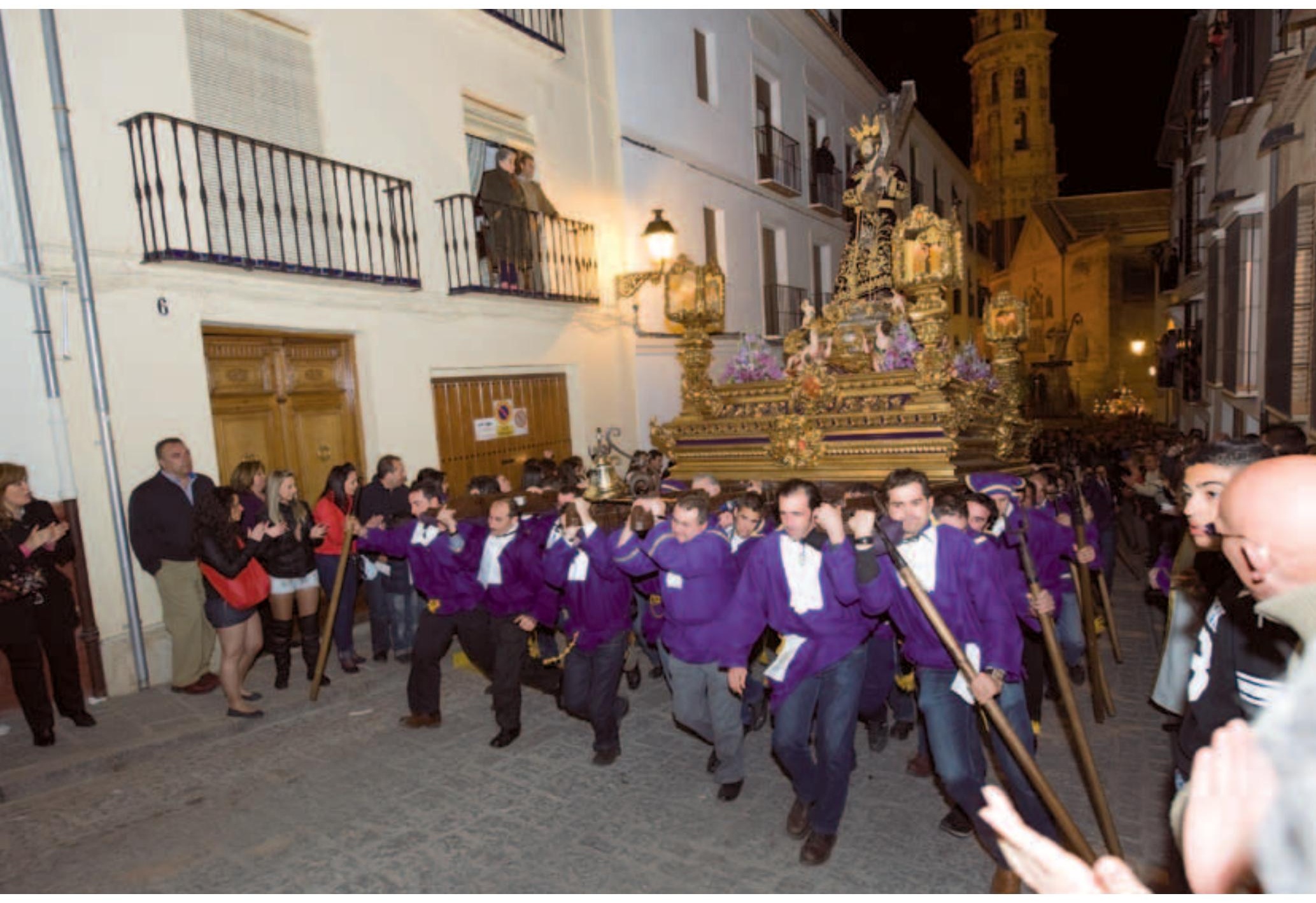

Dulce Nombre de Jesús, de la hermandad de Abajo, corriendo su vega. Foto: Juan Carlos Cazalla, IAPH

suceder, existen varias versiones que tratan de explicar no sólo el hecho sino, sobre todo, su denominación. Una de ellas señala que las imágenes son conducidas a lugares altos de la población para desde ellos bendecir los campos -la vega- para que sigan siendo feraces. Así, el grito de "a la vega" sería una llamada a la bendición sagrada. Y correr la vega sería una especie de rito propiciatorio de fertilidad.

Sin duda, desde la Cruz Blanca se divisan (o, mejor, se divisaban) las huertas. También desde los Cerrillos. Y desde el entorno del Portichuelo -de la capilla-tribuna de la Virgen del Socorro- pueden verse los campos, desde la Peña de los Enamorados hasta casi las cercanías de El Torcal. Pero también existe la versión historicista. Según las crónicas que alimentan la leyenda, el día de la conquista, 16 de septiembre, los cristianos persiguieron a los moros hasta lo alto de la fortaleza llevando con ellos una imagen de la Virgen y los allí sitiados tuvieron que escapar por la vega entregando la ciudad. Así, el grito de guerra para obligarles a huir, para echarlos "a la vega", haciéndoles abandonar el castillo y escapar por los campos, se habría convertido en el
Durante las "vegas" se rompe el dualismo hermano mayor-hermanacos y se establece otra nueva polarización: la de cada trono, con hermanacos y hermanos mayores en gran medida fundidos, y el pueblo anónimo. $Y$ todos corren, delante de la imagen 


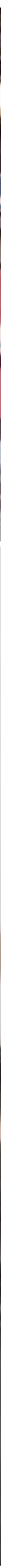

1. Encuentro entre las Vírgenes de los Dolores y del Consuelo, la noche del Jueves Santo.

2. Trono del Cristo de la Misericordia (hermandad del Consuelo) corriendo la vega.

3. La Virgen de la Paz (hermandad de Abajo) corre la vega.

Fotos: Juan Carlos Cazalla, IAPH

grito de ánimo a los hermanacos para que sea posible culminar
Si una u otra versión se ajusta más a la realidad histórica, o si ambas tienen su parte de verdad y su parte de mito, es poco im- portante. Porque lo que explica principalmente el que se sigan corriendo las vegas es que constituyen los momentos de clímax de los rituales semanasanteros antequeranos hasta el punto de haberse convertido en uno de los referentes identitarios de la sociedad local. Por encima de los diversos dualismos, pasados y actuales, e integrándolos. 


\section{El bordado en oro de Archidona}

El taller de Juan Antonio Lara está situado, tal y como él mismo apunta, "en la calle Don Carlos, frente a los Escolapios de Archidona donde estudió Blas Infante". Es una vivienda de arquitectura popular que adapta sus instalaciones a las necesidades del taller. Tras el zaguán, nos recibe la imagen de una virgen vestida, a escala humana, que preside el recibidor de la casa. En la segunda planta, una habitación luminosa con balcón a la calle del mismo nombre hace las veces de sala de bordado donde se instala el bastidor y el armario que guarda los hilos dorados y las pequeñas herramientas.

El origen del taller nace por iniciativa de Juan Antonio, que empieza bordando para su hermandad, y tras unos años en talleres de Málaga, que refuerza con cursos de bordados, monta el taller junto con su hermano, Antonio, y Manolo, un tercer bordador. Juan lleva veintiún años bordando y domina todas las técnicas productivas del taller, aunque, dentro del mismo, cada uno tiene sus propias funciones. Juan documenta e investiga técnicas de bordados de la zona, Antonio realiza los dibujos del diseño y Manolo se encarga del corte.

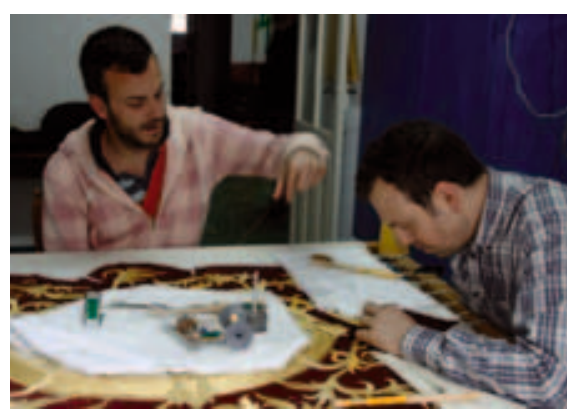

Juan A. y su hermano Antonio en el taller de la calle Don Carlos. Foto: Isabel Aguilar Majarón, IAPH

En el taller la materia prima para el bordado es el hilo de oro, que se obtiene enrollando una lámina de plata sobredorada sobre un hilo de seda. "Los hilos son los colores de la paleta del pintor". De este hilo liso se obtienen otras variedades como el hilo torzal que se logra torciendo sobre sí mismo varios cabos de hilos. Éste, a su vez, presenta otras variedades, dependiendo de los cabos utilizados. El hilo muestra es completamente liso y en su interior lleva otros hilos de seda; es uno de los más usados en el bordado en oro, pero hay que tener mucha maestría en su empleo, por la dificultad que presenta su acabado. El hilo jiraspe es una mezcla de hilo de oro con hilo de seda de distintos colores. El hilo granito es picoteado y su fin es crear este efecto sobre el tejido. El hilo de hojuela es una lámina de plata sobredorada, con el que se perfilan las pinturas centrales de los estandartes. El bordado entonces forma un cordón metálico que simula una pieza de orfebrería.

Tras ser aceptado un encargo, el diseño definitivo se traspasa al papel de seda y se despieza "nosotros tenemos que ir desguazando el dibujo". En algunos casos, los dibujos necesitan despiezarse en cada uno de sus elementos; por ejemplo, una rosa hay que despiezarla pétalo a pétalo. Es un proceso complicado, porque cada elemento debe coincidir después con el dibujo marcado. Este procedimiento se complejiza aún más si la cofradía presenta un escudo con elementos simbólicos (cosa muy habitual). En este caso, las piezas se montan en otro bastidor más pequeño para bordarse aisladamente. Posteriormente se recortan (se le quita la tela de muselina sobrante) y se colocan "como si se confeccionara un puzle". Se van pegando y perfilando. En cambio, en el bordado en cartón, las piezas de cartón (cartulina), ya recortadas, se pegan con pequeñas puntadas sobre la tela del bastidor y se bordan con el hilo de oro. La técnica del bordado en cartón es una de las técnicas de bordado en oro que más gusta en Archidona. El resto de elementos se borda sobre el tejido y los remates finales se perfilan con los acabados.

Fernández de Paz (1998: 387), en su análisis sobre los talleres cofradieros, relaciona los instrumentos (de sujeción y soporte, para medir y trazar, contención, ensamblaje y montaje) y las técnicas productivas con la materia prima empleada. La plasticidad de los hilos de metal dan como resultado la simplicidad de los instrumentos, de la misma manera que las técnicas productivas se definen por su escasa complejidad y por la manualidad en todos sus procesos productivos. El bordado en oro se realiza sobre una tela, generalmente terciopelo, con un forro en el reverso de trama densa (muselina morena). Para ello, la hebra del hilo de oro se pasa de lado a lado fijándola sobe el diseño con pequeñas puntadas de hilos. Esta hebra de seda hay que ir engrasándola con cera, para que no se endurezca y parta. El hilo de oro formará el dibujo en el anverso del textil y debe ir completamente recto este proceso es muy laborioso y hay que ejecutarlo con maestría tensando bien el bastidor. "...Dentro de bordado hay tantas puntadas como bordadores, cada bordador da la puntada según lo que le inspira esa pieza. Pero todo el trabajo tiene que ir enfocado a imitar a la Naturaleza" (Juan Antonio).

Las tipologías de puntadas y bordados más utilizadas en este taller son: de ladrillitos para dar textura de uniformidad, de ladrillito doble para dar mayor uniformidad aún, la puntada en flecha, que va buscando una dirección, la puntada de fresa que imita sus relieves y huecos con pequeños puntitos "uno, dos, tres, dos y uno" (Antonio).

El bordado en cartón (recortes en cartulina), que utiliza distintas texturas, el bordado de hojuela u hojilla es una de las técnicas de bordado más laboriosas, porque con una lámina de plata sobredorada de aproximada-

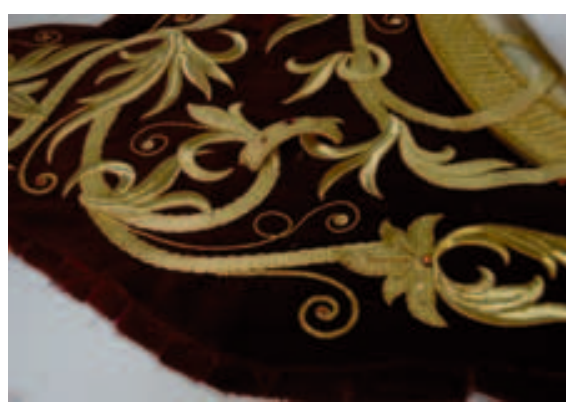

Bordado con incrustaciones en pedrería y motivo de puntada de ladrillitos. Foto: Isabel Aguilar Majarón, IAPH

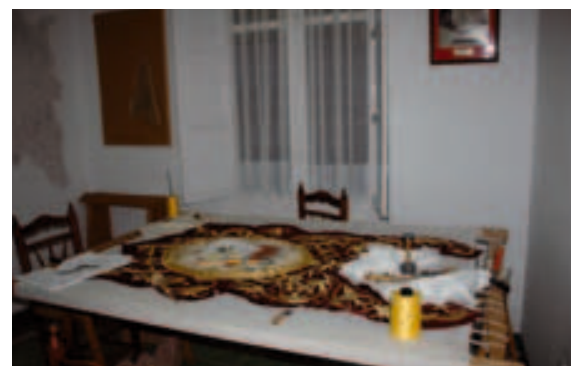

Taller con bastidor, hilos e instrumentos de bordado. Foto: Isabel Aguilar Majarón, IAPH

mente un milimetro de anchura se rellena toda la pieza, puntada a puntada, de manera uniforme. El acabado final es un cordón de oro de gran brillo y redondez.

Los bordados se enriquecen con lentejuelas y piedrecitas en colores de cristal engarzado, para captar la atención del cortejo en cada giro o movimiento.

La característica más señalada de este taller es que en él se reproducen diseños y técnicas de bordados cofradieros del pasado, tanto de Archidona como de otros pueblos de la comarca. Para ello buscan en los antiguos ajuares de las cofradias y en los viejos arcones de las iglesias: "Afortunadamente aqui no hubo mucho expolio durante la guerra asi los que trabajos se investigan y sirven de inspiración para los nuevos encargos recibidos."

En sus diseños, juegan con los relieves y las formas, lo que ellos denominan el "color" y la "textura". Los claros-oscuros se consiguen combinando figuras planas con las de relieve. Buscan crear distintas tonalidades realzando los contrastes contraponiendo figuras en distintas direcciones.

En estos talleres las fases productivas son poco diferenciadas, lo que da como resultado que el tiempo de aprendizaje sea mayor. Como consecuencia, estos centros son los que experimentan menos cambios a lo largo del tiempo. Se mantiene en lo que Fernández de Paz denomina la "paleotecnia" (1998: 395). Es decir, un oficio que, a diferencia de la mayoría, no introduce ningún procedimiento mecánico en sus fases productivas.

El discurso de este taller es recuperar los bordados de la zona, para preservar las variedades locales de los bordados de la Semana Santa "aqui gusta más el bordado en cartón, en Sevilla, por el contrario gusta más el picoteao". Sus encargos generalmente establecen de manera clara que ejecuten la obra con las técnicas de bordados "al gusto de Archidona".

En Archidona aún podemos documentar la presencia de representaciones teatrales en la Hermandad del Huerto. Sus bordados neobarrocos, casi inalterables durante siglos, reafirman el carácter festivo y teatral otrora prohibidos, cuyas supervivencias, casi inalterables en los talleres de bordados, gozan de buenas previsiones de futuro.

Isabel Aguilar Majarón, antropóloga 


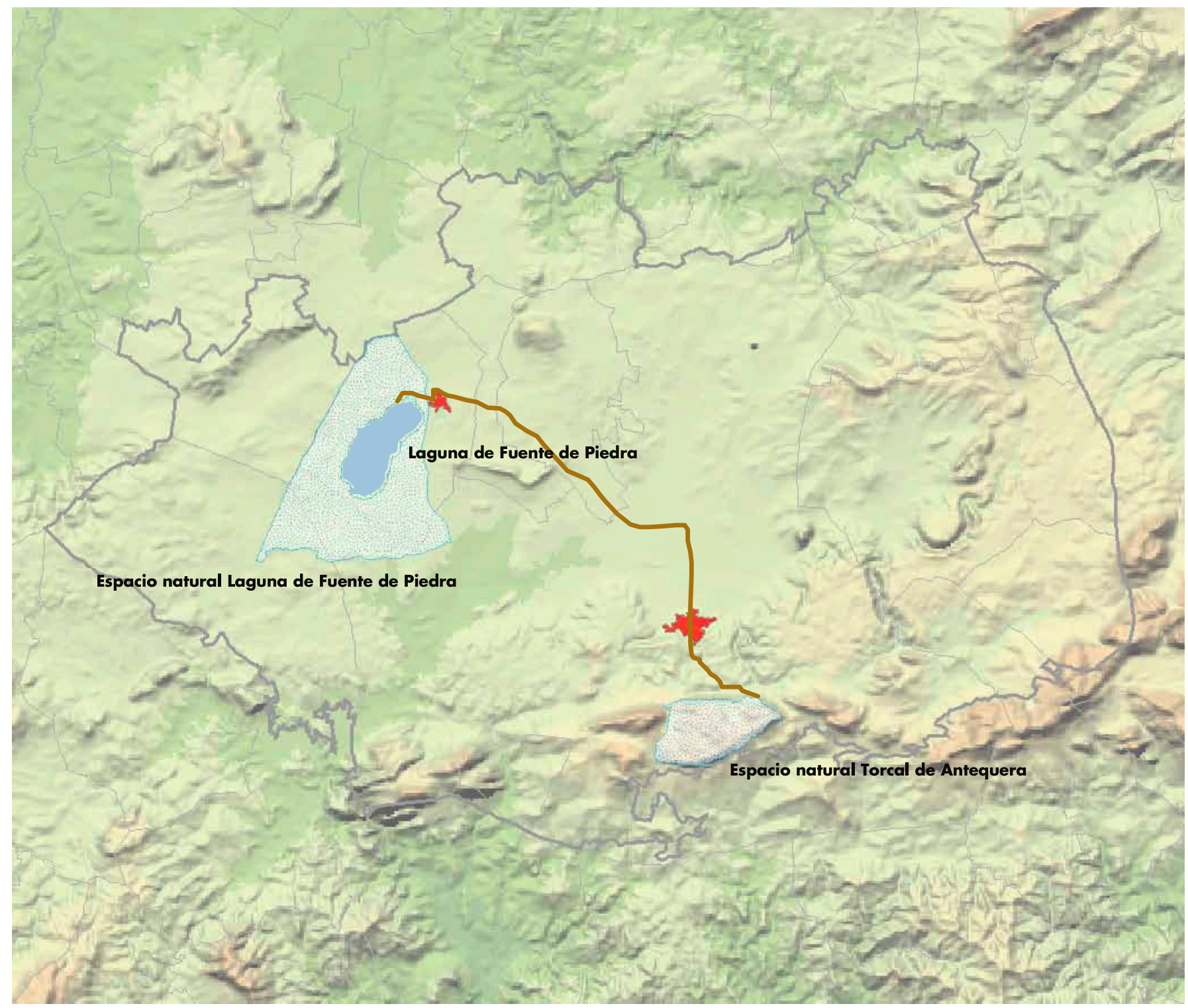

Mapa: Pilar Mondéjar Fernández de Quincoces 


\section{Del Torcal a la Laguna de Fuente de Piedra}

Francisco J. Guerra Rosado, director técnico de Servicios de Educación y Estudios Ambientales, S.L. (SEEDA)
La provincia de Málaga, tierra de mar y montaña, alberga algunos de los espacios naturales más interesantes de nuestra Comunidad Autónoma. Unos son conocidos por sus valores paisajísticos mientras que en otros, la fauna o la flora son los principales protagonistas. Se trata, en todo caso, de espacios singulares con personalidad propia y una gran capacidad para sorprender a propios y extraños.

El itinerario que da nombre a este artículo se desarrolla entre dos lugares radicalmente diferentes que forman parte de la comarca de Antequera; el primero de ellos, El Torcal, es fruto de la lucha permanente e inconclusa, durante millones de años, entre la roca y los agentes atmosféricos. En el otro extremo, la Laguna de Fuente de Piedra, se ha venido dibujando durante los últimos miles de años como consecuencia de la interacción constante entre la naturaleza y la mano transformadora del ser humano. A pesar de sus grandes diferencias, ambos espacios comparten el privilegio de formar parte de la Red de Espacios Naturales Protegidos de Andalucia, siendo dignos contribuyentes a su diversidad tanto biológica como geológica y paisajistica.

El Torcal de Antequera fue el primer territorio andaluz reconocido como Espacio Protegido; así, debido a sus increíbles valores paisajísticos, fue declarado "Sitio Natural de Interés Nacional" en el año 1929. En la actualidad está incluido dentro de la categoría de Paraje Natural (Ley 2/1989, de 18 de julio, del Parlamento de la Comunidad Autónoma Andaluza).

El Torcal está construido por rocas calizas de distintos tipos; en su origen todas ellas formaron parte del fondo marino durante el Jurásico, periodo durante el cual los sedimentos acumulados en el fondo del mar fueron empujados hacia la superficie por las fuerzas generadas en el Plegamiento Alpino. Muestra de ello es el gran número de fósiles de animales marinos que es posible encontrar en el Paraje. Unos de los aspectos más sorprendentes resulta de comprobar cómo gran parte de los estratos mantuvieron su horizontalidad a pesar de las grandes fuerzas intervinientes en el proceso; este hecho, observable a simple vista, es muy poco habitual en las montañas calizas andaluzas.
A partir de entonces la erosión comenzó a esculpir el paisaje a través de los procesos generados por el denominado "modelado cárstico", y en el que las aguas frias, cargadas del dióxido de carbono atmosférico, disuelven las rocas calizas de manera diferencial en función de su dureza y composición. Parte de los materiales disueltos pueden llegar a precipitar a su vez, generando formas singulares como las conocidas estalactitas y estalagmitas.

Por otro lado, el agua absorbida por la roca se congela por la acción del frío dando lugar a la llamada gelifracción, es decir, la fractura de la roca por la acción de cuña producida por el hielo. En el caso concreto del Torcal, la gelifracción, junto con la disolución diferencial de materiales de distinta dureza, han modelado en las rocas una gran cantidad de formas que, como mínimo, podriamos calificar como sorprendentes.

El resultado de este conjunto de procesos ha sido la creación de una auténtica colección de esculturas naturales a las que la imaginación humana ha asociado con elementos de la vida cotidiana; en este sentido, algunas de las formas más conocidas han recibido nombres como "El Tornillo" (cuya imagen fue adoptada como logotipo de este espacio protegido), "el Sombrerillo", "el Macetón", "el Camello", "el Ataúd", o "el Cáliz", entre otros muchos.

Además de todas estas formas propias de la superficie, el corazón del Torcal ofrece una enorme riqueza en simas, cuevas y otras formas subterráneas y cuyo origen no es otro que los procesos de disolución ya mencionados asi como la precipitación de las calizas arrastradas por la acción del agua de lluvia.

Por otro lado, y aunque sus valores más evidentes son geológicos y paisajísticos, El Torcal posee una flora rica y variada, lo cual acrecienta en gran medida la importancia de sus valores naturales. Si bien es cierto que la mayor parte de los bosquetes que originalmente lo tapizaban han desaparecido como consecuencia de la acción antrópica, especialmente la tala, el carboneo y la actividad ganadera, aún es posible localizar algunos rincones que conservan restos de la vegetación original así como diversas especies endé- 

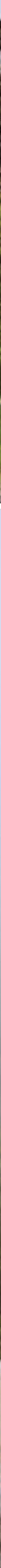

1. Vista del Torcal desde la ruta verde.

2. Estratos horizontales típicos del Torcal y poco habituales en las montañas calizas andaluzas.

3. Formas esculpidas en el paisaje del Torcal por el denominado "modelado cárstico".

4. El tornillo y su entorno.

5. El tornillo, monumento natural, símbolo del Torcal.

Fotos: Juan Carlos Cazalla, IAPH 
micas junto a otras de interés desde el punto de vista florístico. El inventario botánico del Torcal registra al menos 664 especies de plantas (12 especies de líquenes, 77 de musgos y hepáticas, 10 de helechos y 565 de plantas con semilla).

De las distintas comunidades vegetales existentes en el Paraje, la que mayor importancia posee desde el punto de vista botánico es la de las plantas rupicolas. Se trata de especies especialmente adaptadas a crecer en las fisuras y grietas de las rocas calizas en unas condiciones realmente duras para la vida. Muchas de estas especies tienen carácter endémico (esto significa que poseen una distribución geográfica muy restringida) por lo que su futuro exige normas muy estrictas de conservación, como ha sido la creación de un área de reserva dentro de la zona conocida como el Torcal Alto.

También la fauna tiene importancia en El Torcal. En este sentido, es de destacar la riqueza en aves que posee, y fue por lo que esta sierra fue declarada como Zona Especial para la Protección de las Aves (Z.E.P.A.), en virtud de la Directiva Comunitaria n 79/409; cuenta con especies como el águila real, el halcón peregrino o el águila perdicera, a las que hay que unir una rica variedad de reptiles, mamíferos y, sobre todo, insectos.

Los seres humanos han estado presentes en El Torcal desde la Prehistoria, como atestiguan algunos yacimientos neolíticos como el de la Cueva del Toro. Restos de origen romano apuntan también al uso del Torcal como cantera de cara a la construcción de villas próximas como Anticaria, Osqua y Nescania.

El Torcal es un espacio especialmente adaptado al uso público. Entre las iniciativas que colaboran a su puesta en valor destacan el centro de visitantes, inaugurado en octubre de 2009, y que cuenta con una exhibición interpretativa; el Mirador de las Ventanillas, que ofrece unas vistas de Villanueva de la Concepción y la comarca del Río Campanillas; y una red de senderos señalizados, como la "Ruta Verde-Sendero del Torcal Alto" y la "Ruta Amarilla", de diferente duración y grado de dificultad.

La bajada desde El Torcal a la localidad de Antequera, que descansa a sus pies, ofrece unas vistas impresionantes de los valles de Antequera y Archidona. En contraste con la naturaleza más o menos salvaje del Torcal el camino que nos lleva hasta Fuente de Piedra nos muestra un espacio de clara vocación agrícola y en cuyos paisajes -en los que la llanura es la constante- destacan el olivar, el viñedo, el cereal o el girasol. Se trata de un lugar absolutamente transformado del que sólo algunas lagunas y árboles aislados nos recuerdan el pasado natural de estas tierras.

En medio de este paisaje tan absolutamente humanizado, y junto a la localidad de Fuente de Piedra, encontramos la Laguna del mismo nombre. La configuración actual de este espacio es un reflejo de las distintas actuaciones que el ser humano ha llevado a cabo a lo largo de la Historia, unas veces para para tratar de desecarla y otras para aprovechar su sal.
Restos de origen romano

apuntan también al uso del

Torcal como cantera de cara

a la construcción de villas

próximas como Anticaria, Osqua y Nescania

El nombre de la localidad, y por tanto de la laguna, está relacionado con la existencia de una fuente de agua a la que se atribuian propiedades curativas para el mal de piedra y el estómago. Ya en tiempo de la ocupación romana se conocian estas propiedades curativas que llevaron a bautizar el lugar con el nombre de "Fons Divinus".

La laguna tiene sus orígenes, hace unos cinco millones de años, en el Plioceno. Como consecuencia del hundimiento de la cuenca o el aumento del nivel del mar se depositaron materiales marinos en el fondo. Más tarde estos materiales se plegaron dando origen a unos relieves más o menos pronunciados que paulatinamente la erosión se encargó de ir rellenando con materiales sedimentarios. Consecuentemente, aparecen una serie de arroyos que fueron convergiendo en las partes más deprimidas de la zona, formándose una pequeña laguna al no encontrar las aguas ninguna otra salida.

Actualmente, su entorno tiene pendientes muy suaves con altitudes que oscilan entre los 410 y los 434 metros sobre el nivel del mar.

Los numerosos yacimientos romanos encontrados en los alrededores de la laguna ponen de relieve la explotación que éstos hicieron de las salinas. La sal era una fuente de riqueza de primer orden, hasta el punto de usarla como moneda de pago. También obtenian de la laguna otro bien muy preciado en su gastronomía: el flamenco. Los romanos consideraban a esta zancuda como un extraordinario regalo culinario, especialmente por su lengua a la que incluian entre sus platos más exquisitos.

En 1697 el médico Alfonso Limón Montero describe en su obra Espejo Cristalino de las Aguas cómo distintos doctores y personajes relevantes de Archidona y Antequera coincidian en que era un agua muy dulce y fría en verano y que, por su singularisima virtud de curar toda enfermedad de piedra en los riñones y vejiga y de confortar el estómago, la habian Ilevado a Italia y hasta las Indias. Con la llegada del siglo XIX empezaron los intentos de desecar la laguna; incluso se constituyó una empresa destinada a tal fin pero el ayuntamiento de Antequera recurrió al rey para paralizar el proyecto. En 1876 se iniciaron una serie de obras para mantener el nivel de agua y evitar el arrastre de las sales con las aguas dulces de escorrentía, favoreciendo la explotación de las salinas. 

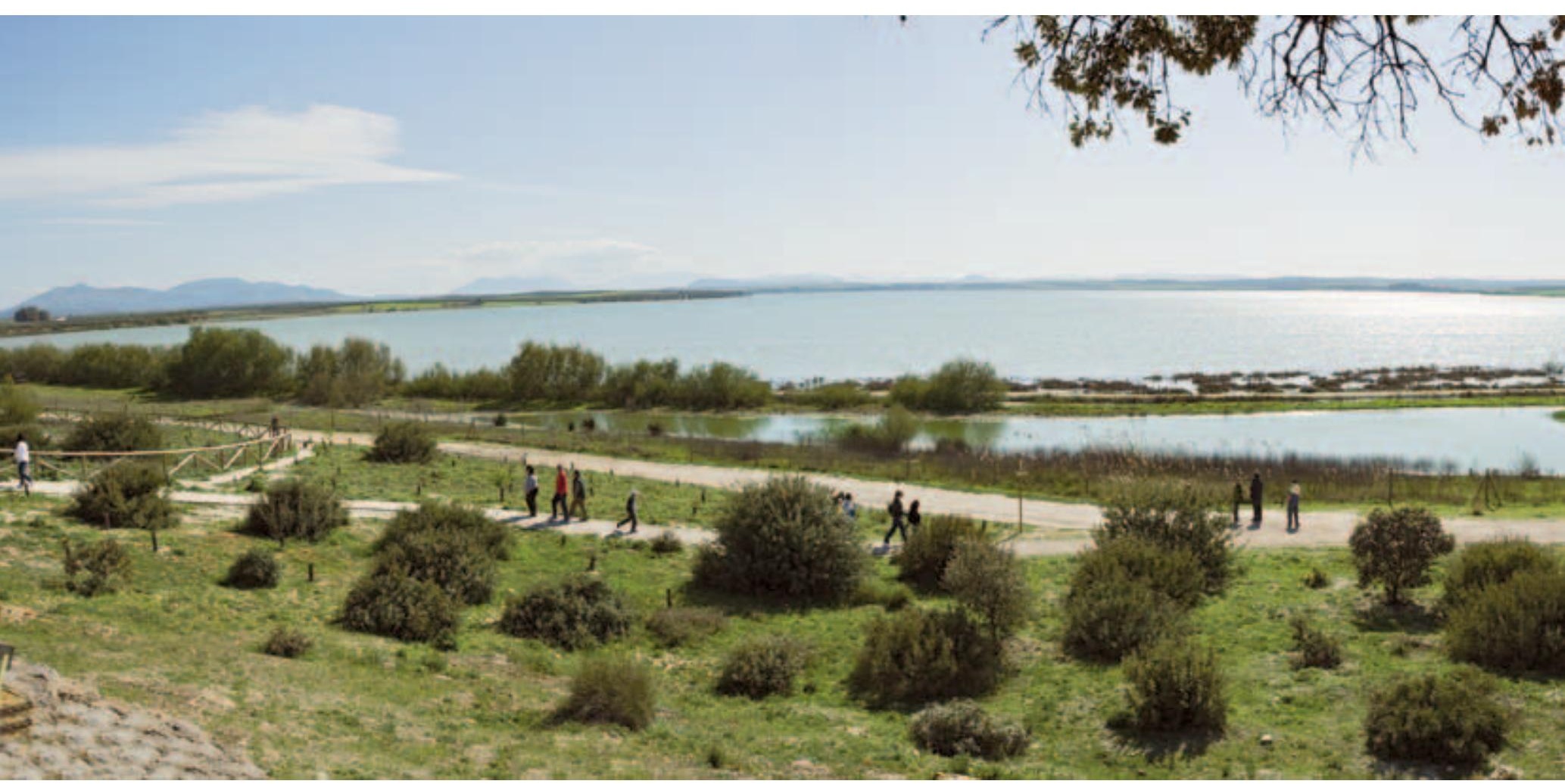

Vista panorámica de la Laguna de Fuente de Piedra desde el centro de visitantes.

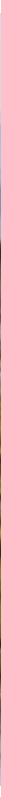

Grupo de flamencos en la Laguna de Fuente de Piedra.

Fotos: Juan Carlos Cazalla, IAPH 

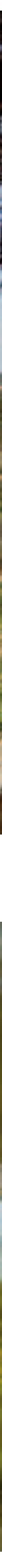

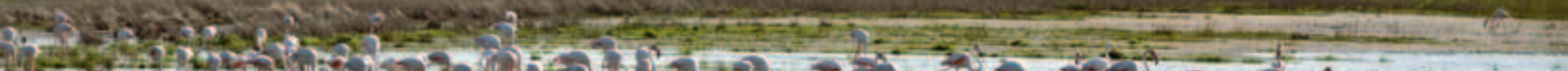

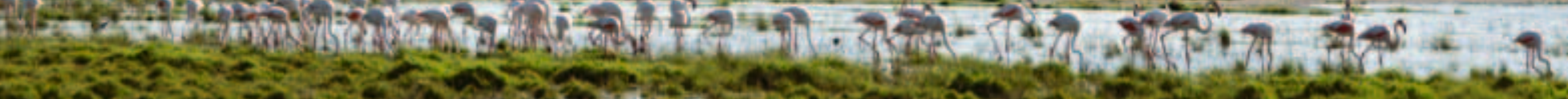

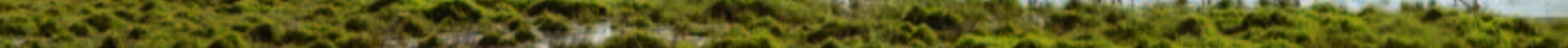

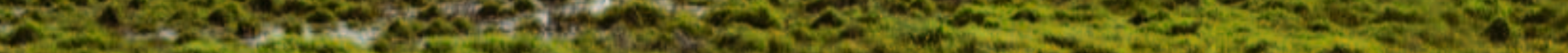

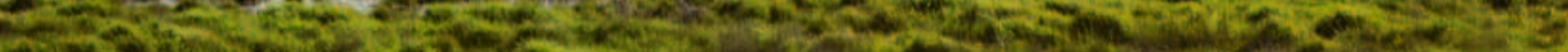

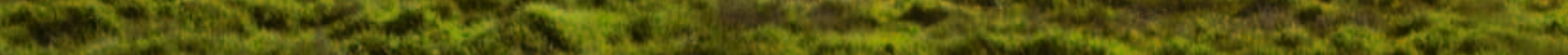

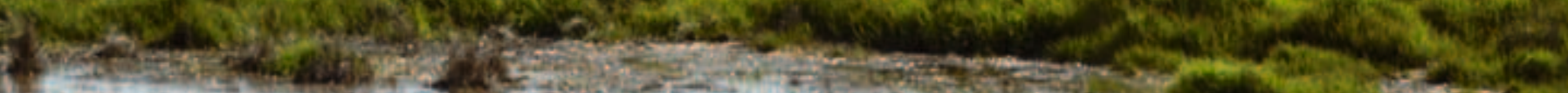

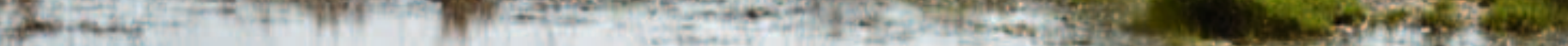




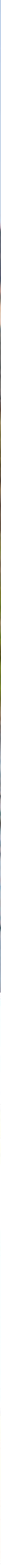

1. Flamencos en las inmediaciones de la Laguna de Fuente de Piedra.

2. Centro de visitantes de la Laguna de Fuente de Piedra.

3. Observador de aves.

Fotos: Juan Carlos Cazalla, IAPH 
Por otro lado, se dividió el vaso lagunar mediante diques, canales y estanques de evaporación (condensadores y cristalizadores) creando las estructuras propias de una explotación salinera. Todas estas acciones estaban encaminadas a favorecer la concentración salina del agua de la laguna con vistas a la producción de sal. En este periodo la laguna podia producir $20.000 \mathrm{~m}^{3}$ anuales de sal.

Desde 1958 distintos científicos, con José Antonio Valverde a la cabeza, hicieron diferentes observaciones y estudios sobre la colonia nidificante de flamencos. En 1962, en la Primera Conferencia Internacional sobre las Marismas (MAR) a instancias de la UICN (Unión Internacional para la Conservación de la Naturaleza) se incluyó la Laguna de Fuente de Piedra en la lista de las zonas húmedas a proteger y se intentó cambiar el criterio vigente de que las zonas encharcadas y pantanosas eran focos de infección que debian erradicarse.

En 1983 fue incluida entre los Humedales de Importancia Internacional (Convenio Ramsar) y el 9 de enero de 1984 fue declarada Reserva Integral por el Parlamento de Andalucía (Ley 1/1984), pasando a denominarse Reserva Natural tras su inclusión en el Inventario de Espacios Naturales Protegidos de Andalucía (Ley 2/1989, de 18 de julio).

La Reserva Natural comprende la propia laguna y unos cien metros más allá de su periferia, ocupando un total de 1.554 hectáreas. Alrededor de este espacio está declarada una Zona Periférica de Protección que tiene una extensión de 6.689 hectáreas.

Los restos de la antigua explotación salinera han diversificado la extensa planicie del vaso lagunar, dando lugar a islotes, depresiones y canales de agua dulce. Estas estructuras artificiales han generado heterogeneidad ambiental que ha permitido el asentamiento de especies vegetales y animales diferentes.

La Laguna de Fuente de Piedra es singular por su gran tamaño, la escasa profundidad de sus aguas, su enclave geográfico, la elevada salinidad de sus aguas y su singularidad geomorfológica. Todo ello le confiere una especial relevancia desde el punto de vista ecológico, cultural, didáctico y científico.

El valor de la laguna se refuerza al formar parte, junto a otros espacios de la Comunidad Autónoma, de una red o sistema que permite la conexión entre distintas áreas naturales, contribuyendo a la preservación, proliferación y dispersión de especies animales. El nivel de agua de la laguna está muy determinado por las condiciones climáticas reinantes en cada momento. Puesto que el clima mediterráneo se caracteriza por la estacionalidad de las Iluvias y éstas no son muy abundantes (la precipitación media anual es de $460 \mathrm{~mm}$ ), la laguna sufre periodos más o menos largos de desecación. Además, hay también una gran variación en la distribución interanual de las precipitaciones de manera que algunos años se superan los $700 \mathrm{~mm}$ y en otros apenas se alcanzan los 200.

\section{El nombre de la localidad, y por tanto de la laguna, está relacionado con la existencia de una fuente de agua a la que se atribuian propiedades curativas para el mal de piedra y el estómago}

La salinidad de sus aguas se debe a la disolución de las abundantes sales existentes en algunos de los materiales más antiguos, y de naturaleza arcillosa, que componen el terreno donde se asienta. Cuando tierra y agua se mezclan, la primera le trasfiere las sales y la saliniza. Cuando esa agua se evapora los minerales se hacen sólidos, en forma de pequeños cristales, y quedan en la superficie. Las condiciones ambientales tan severas de la laguna condicionan la existencia de comunidades de seres vivos singulares adaptadas a este ambiente fluctuante, y entre las que destacan los microorganismos.

Puesto que este humedal tiene la particularidad de que la mayor parte del agua es salobre, las especies vegetales, además de estar adaptadas a un mayor o menor grado de inundación, soportan distintos grados de salinidad del suelo (plantas halófitas), mediante una serie de adaptaciones específicas para evitar el envenenamiento por el exceso de sales.

Pero si por algo es internacionalmente conocido este espacio es por constituir el enclave más importante de España donde se reproduce con regularidad el flamenco común (Phoenicopterus ruber roseus), siendo la colonia nidificante, junto con la existente en la Camarga francesa, la más relevante de Europa y del Mediterráneo occidental.

El número de flamencos en Fuente de Piedra varía cada año como consecuencia de la fuerte estacionalidad. En los años húmedos se produce una gran concentración de efectivos entre los meses de febrero y julio, realizando la cría durante los meses de abril a junio. Nidifica sobre bancos de fango y cuando el nivel de agua es muy elevado, lo hace sobre los diques y "canchones" que sobresalen del agua a modo de islotes.

La avifauna acuática de la laguna es fluctuante, tanto en efectivos como en especies, ya que está muy condicionada por el nivel de agua, la salinidad y la duración del periodo de encharcamiento. En años secos en nivel de agua es bajo y se forman playas que favorecen la presencia de limícolas. Por el contrario, en los años más húmedos aumenta la presencia de patos nadadores y si el nivel de agua es alto proliferan las especies buceadoras.

Fuente de Piedra, al igual que El Torcal, posee un conjunto de equipamientos y servicios dirigidos a su puesta en valor. En este sentido cuenta con un centro de visitantes, un itinerario que rodea perimetralmente la laguna y una serie de senderos peatonales de corto recorrido así como observatorios para la fauna. 
ACIÉN ALMANSA, M. (1997) Entre el feudalismo y el Islam. 'Umar ibn Hafsûn en los historiadores, en las fuentes y en la historia. Jaén: Servicio de

Publicaciones Universidad de Jaén, 1997

AGUDO TORRICO, J. (2004) Espacios y cortejos ceremoniales. En FERNÁNDEZ DE PAZ, E. (dir.) Artes y Artesanías de la Semana Santa Andaluza, v. 9. Sevilla: Tartessos, 2004 *

ALONSO MARTÍNEZ, I.; OLARTE, J. B.; LÓPEZ DE SILANES VALGAÑÓN, J. I.; GARCÍA CUBILLAS,

J. L. (2006) Las cuevas de Herrera/San Felices ¿un eremitorio cristiano? Espacio y tiempo en la percepción de la Antigüedad Tardia. Antigüedad y cristianismo, n. ${ }^{X X I I I, ~ 2006, ~ p p . ~ 685-712 ~}$

ARJONA ARCAS, J. et ál. (1985) Plan Rector de Uso y Gestión de la reserva Integral Laguna de Fuente Piedra. Sevilla: Agencia de Medio Ambiente, Junta de Andalucía, 1985

ATENCIA PÁEZ, R. (1988) La ciudad romana de Singilia Barba (Antequera - Málaga). Málaga: CEDMA, 1988

BLASCO, M.; LUCENA, J.; RODRÍGUEZ, J. (1979) Los flamencos de Fuente Piedra. Madrid: Ministerio de Agricultura, ICONA, 1979

CABAÑAS, R. (1968) El Torcal de Antequera. Guía turística y documental. Barcelona: Editorial Alpina, 1968

CABRERA, F. (DE) (1679) Descripción de la fundación, antigüedad, lustre y grandezas de la muy noble ciudad de Antequera. Obra póstuma corregida y aumentada por don Luis de la Cuesta, Archivo Municipal de Antequera, fol. 5 r. y Vo

EI CINE Torcal en construcción. Nueva Revista, agosto 1933

DOCOMOMO, un lugar en el patrimonio : especial [Sección Información de Bienes Culturales]. PH : Boletín del Instituto Andaluz del Patrimonio Histórico, no 15, junio 1996, pp. 110-166.

DOCOMOMO : dossier. PH: Boletín del Instituto Andaluz del Patrimonio Histórico, no 28 septiembre 1999, pp. 80-136

ESCALERA REYES, J. (1997) La fiesta como patrimonio. PH Boletín del Instituto Andaluz de Patrimonio Histórico, n. 21 , 1997, pp. 53-58 *
GONZÁLEZ BLANCO, A. La investigación sobre las cuevas. La Cueva de La Camareta. Antigüedad y cristianismo. n. ${ }^{\circ} X_{1} 1993$, pp. $15-40$

FERNÁNDEZ DE PAZ, E. (2006) Actividades Artesanas: cambios socioeconómicos, continuidad cultural. PH Boletín del Instituto Andaluz de Patrimonio Histórico, n. ${ }^{\circ}$ 59, 2006, pp. 66-75*

FERNÁNDEZ DE PAZ, E. (2004) Fondo Andaluz de Recuperación del Conocimiento Artesano. Sevilla: Consejería de Economía y Hacienda, Universidad de Sevilla, 2004*

\section{FERNÁNDEZ RODRÍGUEZ, L. E.; ROMERO}

RÉREZ, M. (2007) Las necrópolis en el entorno de Antikaria y Singilia Barba. Bases para su estudio sistemático. Mainake, n. ${ }^{\circ}$ XIX, 2007, pp. $9-32$ *

FERNÁNDEZ DE PAZ, E. (1998) Los Artifices Sevillanos de la Semana Santa Andaluza: el Ornato Tradicional. Sevilla: Ayuntamiento de Sevilla, 1998 *

FUENTES TORRES, M. A. (2008) Inventario desnudo. Aproximación al hecho creativo de Antequera. En ESCALANTE JIMÉNEZ, J. (coord.) La Memoria Dormida. Antequera: Excmo. Ayuntamiento de Antequera, 2008

GARCÍA CANCLINI, N. (1982) Las culturas populares en el capitalismo. México: Casa de las Américas, 1982

LARA GARCíA, M. J. (2008) Historia del cine en Málaga. Isla de Arriarán, n. 8, 2008, pp. 21-37

LEÓN LÓPEZ, M. E. (1993) La laguna de Fuente Piedra. Consejería de Educación y Ciencia de la Junta de Andalucía, 1993

LEÓN VARGAS, M. (2009) El mundo cofradiero antequerano: escenario de litigios entre la familia de los Narváez y los Chacones (siglos XVI-XIX). En SORIA MESA, E.; BRAVO CARO, J. J. (ed.) Las élites en la época moderna: la Monarquía española. Córdoba: Universidad de Córdoba, 2009, v. 4, pp. 259-280

MAD0Z, P. (1986) Diccionario geográficoestadístico-histórico de España y sus posesiones de ultramar. Málaga. Editorial Ámbito. Valladolid. Edición Facsímil *

MARTÍNEZ ENAMORADO, V. (2003) Al Andalus desde la periferia: la formación de una sociedad musulmana en tierras de Málaga (siglos VIII-X). Málaga: CEDMA, 2003

MARTíNEZ LÓPEZ, A. (1998) Pervivencias romano cristiana en el mundo posterior, el mundo de las creencias: Cuevas, sepulturas y mezquitas. Romanización y Cristianismo en la Siria Mesopotámica. Antigüedad y cristianismo, n. ${ }^{\circ}$, 1998, pp. 465-476

MOLINA GÓMEZ, J. A. (2006) La cueva y su interpretación en el cristianismo primitivo. Espacio y tiempo en la percepción de la Antigüedad Tardía. Antigüedad y cristianismo, n. ${ }^{X X I I I, ~ 2006, ~ p p . ~ 861-880 ~}$

MOLINA GÓMEZ, J. A. (2006) Recorrido por la geografía del monacato rupestre cristiano. Una interpretación histórica. Espacio y tiempo en la percepción de la Antigüedad Tardia. Antigüedad y cristianismo, n. XXIII, 2006, pp. 649-675

MOLINA GÓMEZ, J. A. (1998) El monacato cristiano en Siria. Introducción, problemas y propuestas. Romanización y Cristianismo en la Siria Mesopotámica. Antigüedad y cristianismo. n. $X_{\text {V }}$ 1998, pp. 379-397

MORENO NAVARRO, I. (1999) [1974] Las hermandades andaluzas. Una aproximación desde la Antropología. Sevilla: Publicaciones de la Universidad de Sevilla (2a edición ampliada), 1999

MORENO NAVARRO, I. (2000a) La Semana Santa. En CANO GARCÍA, G. (dir.) Conocer Andalucia. Gran Enciclopedia Andaluza del siglo XXI. Sevilla: Tartessos, 2000, v. 6, pp. 218-255*

MORENO NAVARRO, I. (2000b) Identificaciones colectivas, Modernidad y Cultura andaluza: la Semana Santa de Sevilla en la era de la globalización. En HURTADO SÁNCHEZ, J. (ed.) Religiosidad popular sevillana. Sevilla: Área de Cultura del Ayuntamiento de SevillaUniversidad de Sevilla, 2000, p.237-253

MORENO NAVARRO, I. (2002) Cultura andaluza, patrimonio cultural y políticas de 
patrimonio. En Demófilo. Revista de Cultura Tradicional, Tercera Época, n. ${ }^{\circ}$ 1, pp. 71-87. Sevilla: Fundación Machado, 2002 *

MORENO NAVARRO, I. (2006a) La Semana Santa en la cultura andaluza. En FERNÁNDEZ DE PAZ, E. (dir.) Artes y Artesanías de la Semana Santa Andaluza. Sevilla: Tartessos, 2006, v. 1, pp. $8-37^{*}$

MORENO NAVARRO, I. (2006b) La Semana Santa de Sevilla. Conformación, Mistificación y Significaciones. $5^{\text {a }}$ edición. Sevilla:

Ayuntamiento de Sevilla, Instituto de la

Cultura y las Artes, 2006

MORENO NAVARRO, I. (2006c) (coord.) La Semana Santa como Patrimonio Cultural de Andalucía. En FERNÁNDEZ DE PAZ, E. (dir.) Artes y Artesanias de la Semana Santa Andaluza, v. 1. Sevilla: Tartessos, 2006

MORENO NAVARRO, I. (2008) La Semana Santa andaluza como "hecho social total": continuidades, refuncionalizaciones y resignificaciones". En ALONSO PONGA, J. L.; ÁlVAREZ CINEIRA, D.; PANERO GARCÍA, P.; TIRADO MARRO, P. (coord.) La Semana Santa. Antropología y Religión en Latinoamérica. Valladolid: Ayuntamiento de Valladolid, 2008, pp. 193-205

MORENO NAVARRO, I. (2010) Rituales festivos e identidades colectivas en tiempos de glocalización. En MARCOS ARÉVALO, J.; RODRIGUEZ BECERRA, S.; LUQUE BAENA, E. (ed.) NOS-OTROS: Miradas antropológicas sobre la diversidad. Mérida: Asamblea de Extremadura, 2010, v. II, pp. 725-748

MORENO NAVARRO, I.; TÁVORA, P. (1989)

Encuentros de Pasión: Semana Santa de Antequera. Programa de la serie De Año en Año. TVE, Sevilla, De Arco Producciones Cinematográficas, 1989

\section{MUÑOZ HIDALGO, F.; GARCÍA CAÑERO,}

R. (1983) Historia de Fuente Piedra. Madrid: Edición de los autores, 1983

MUÑOZ HIDALGO, F. (1998) Crónica de Fuente de Piedra y su laguna salada. Málaga: Diputación Provincial, 1998
PAREJO BARRANCO, A. (1987) Historia de Antequera. Antequera: Publicaciones de la "Biblioteca Antequerana" de la Caja de Ahorros de Antequera, 1987, XXI

PUERTAS TRICAS, R. (1974) Cuevas artificiales de época altomedieval en Nájera. Berceo, 86 1974, pp. 7-20

PUERTAS TRICAS, R. (2007) Iglesias rupestres de Málaga. Málaga: Diputación Provincial, 2007 *

ROMERO BENÍTEZ, J. (1989) Guía Artística de Antequera. Antequera: Publicaciones de la "Biblioteca Antequerana" de la Caja de Ahorros de Antequera, 1989, XIV

ROMERO PÉREZ, M. (1994) La necrópolis romana de Las Maravillas. Bobadilla. Málaga. Mainake, n.XV-XVI, 1994, pp. 195-222*

ROMERO PÉREZ, M. (1998) Algunas reflexiones sobre la producción de aceite en las villae de la comarca de Antequera. Mainake, n. ${ }^{\circ}$ XIX-XX, 1998, pp. $115-141^{*}$

ROMERO PÉREZ, M. (2010) Las villas romanas de la Depresión de Antequera. Influencia romana en nuestros territorios: el Efebo de Antequera. Sevilla: Consejería de Cultura de la Junta de Andalucía, en prensa

ROMERO GONZÁLEZ, M. (1999) Torcal de Antequera. Guía de visita. Málaga: Arguval, 1999

\section{ROMERO GONZÁLEZ, M.; SALAZAR}

FERNÁNDEZ, J. (2002) Fauna de vertebrados. Torcal de Antequera. Málaga: Aneax Editores, 2002

SERRANO RAMOS, E. (1991) Terra Sigillata Hispánica de los Alfares de Singilia Barba. Málaga: CEDMA, 1991

SERRANO RAMOS, E.; ATENCIA PÁEZ, R.; DE LUQUE MORAÑO, A.; RODRÍGUEZ OLIVA, P. (1991) Informe de las excavaciones arqueológicas realizadas en la ciudad romana de Singilia Barba (Antequera) en la campaña de 1989. Anuario Arqueológico de Andalucía 1989, Tomo II. Sevilla: Junta de Andalucía, Consejería de Cultura. Dirección General de Bienes Culturales, 1991, pp. 269-279 *
SERRANO RAMOS, E. (1998) Centros productores de Terra Sigillata hispánica en los territorios malacitanos. En ISABEL FERNÁNDEZ GARCIA (ed.) Terra Sigillata Hispánica: Estado de la Investigación. Jaén: Universidad de Jaén, 1998, pp. $167-185^{*}$

W. AA. (2007) Torcal de Antequera, Lagunas Fuente de Piedra, Campillos, Ratosa y Archidona: itinerarios a pie, en bicicleta, y en coche. Granada: Editorial Penibética, 2007

W. AA. (1999) Catálogo de la exposición MOMO Andalucía. Arquitectura del movimiento moderno en Andalucía 1925-1965. Sevilla: Consejería de Obras Públicas y Transportes, Junta de Andalucía, 1999 *

YELO TEMPLADO, A. (1993) Monacato mozábare, aproximación al oriente de AlAndalus. La Cueva de La Camareta. Antigüedad y cristianismo, n. ${ }^{\circ}$, 1993, pp. 453-466 *

Las publicaciones marcadas con asterisco $\left({ }^{*}\right)$ se encuentran disponibles para su consulta en la Biblioteca del IAPH. El resto de las referencias se han localizado en diversas fuentes de información (REBIUN, DIALNET, Base de datos de Bibliografía de patrimonio histórico, CSIC...) de ámbito nacional. 
AGUILAR GARCÍA, M.D. La plaza ochavada de Archidona. Jábega, no 1, 1973, p. 43-45

ALARIO LÓPEZ, R.; PINO CABELLO, S. del; SALGADO ORDÓÑEZ, R. La rehabilitación del Pósito de Antequera. Sociedad : Boletín de la Sociedad de Amigos de la Cultura de Vélez Málaga, n 4, 2005, p.13-18

ANTEQUERA, en el recuerdo : la Comarca de Antequera en el Archivo Fotográfico Temboury [catálogo de exposición]. Málaga : CEDMA, D.L. 2007

ANTEQUERA : Plan Especial de Protección, Reforma Interior y Catálogo del Centro Histórico. Sevilla : Consejería de Obras Públicas y Transportes, 1995 *

AROUITECTURA del movimiento moderno : registro DOCOMOMO ibérico $=$

Architecture of the modern movement : Iberian DOCOMOMO register : 1925-1965. [Barcelona] : Fundación Mies van der Rohe, D.L. 1996 *

La ARQUITECTURA moderna en Andalucía : un patrimonio por documentar y conservar : la experiencia DOCOMOMO. [Sevilla] : Instituto Andaluz del Patrimonio Histórico ; [Granada] : Comares, 1999, Cuadernos ; 11) *

ARTES y artesanías de la Semana Santa andaluza. V.4: Bordados en oro y sedas. Sevilla : Tartessos, 2003-2006*

BARRIOS ESCALANTE, Ma Concepción [et al.]. Semana Santa de Málaga. Málaga : Arguval, D.L. 1990, (Patrimonio Artístico de las Cofradias ; 5) *

BRAVO PÉREZ, Julio. La Pasión en Antequera. Málaga : Miramar, 2003

CENTRO de Documentación y Biblioteca Virtual de la Prehistoria de Andalucía Antonio Arribas : conjunto arqueológico dólmenes de Antequera. [Sevilla?] : Junta de Andalucía, Consejería de Cultura, [200-?] *

CORRALES AGUILAR, P. El poblamiento romano en el actual municipio de Archidona (Málaga): nuevas aportaciones para su estudio.
Baética : estudios de arte, geografía e historia, $n^{\circ} 27,2005$, p. 283-298 *

CORTIJOS, haciendas y lagares : arquitectura de las grandes explotaciones agrarias de Andalucía : provincia de Málaga. [Sevilla] : Consejeria de Obras Públicas y Transportes, Dirección General de Arquitectura y Vivienda, $2000^{*}$

DÓLMENES de Antequera : plan director del conjunto arqueológico : documento previo al avance. [Sevilla] : Junta de Andalucía, Consejería de Cultura, [200-?] *

DÓLMENES de Antequera : proceso de institucionalización de la tutela 1530/2009. [Sevilla : Consejería de Cultura, 2009 *

ESCALANTE JIMÉNEZ, J. Guía del Archivo Histórico Municipal de Antequera. Antequera (Málaga) : Ayuntamiento, 2007

ESCALANTE JIMÉNEZ, J. Inventario del fondo de hermandades y cofradías del Archivo Histórico Municipal de Antequera. Revista de estudios antequeranos, no 13, p. 261-280

FERNÁNDEZ RODRÍGUEZ, L. E.; ROMERO PÉREZ, M. Las necrópolis en el entorno de "Antikaria" y "Singilia Barba": bases para su estudio sistemático. Mainake, nº 29, 2007, p. $401-432$ *

FERNÁNDEZ RUIZ, J.; MÁROUEZ ROMERO,

J. E. Dólmenes de Antequera : guía oficial del conjunto arqueológico. Sevilla : Consejería de Cultura, 2009 *

FONDO Andaluz de Recuperación del Conocimiento Artesano. Dvd 1. Arte pastoril. Artesonado Bordado en oro. Bordado en tul. Encaje de bolillos. Sevilla : Consejería de Turismo, Comercio y Deporte, $2005^{*}$

FUIXENCH NAVAL, J. M. Santuarios rupestres de España : rincones de leyenda. Zaragoza : Prames, 2007

GARCÍA VALLET, Rocío [et al.]. Guía Comarca Antequera [+ $C d-R O M]$, [2a ed.]. Mollina (Málaga) : Gadl-cant, 2005 *
GOZALBES CRAVIOTO, C.; GONZALBES

BUSTO, G. Antequera y su comarca, según un viajero alemán del siglo XVI (1599). Revista de estudios antequeranos, no 4, 1996, p. 199-214

GUÍA artística de Málaga y su provincia. Sevilla : Fundación José Manuel Lara, 2006, 2 v. *

GUÍA de paisajes urbanos y naturaleza de la Sierra Norte de Málaga : Archidona, Cuevas Bajas, Cuevas de San Marcos, Villanueva de Algaidas, Villanueva del Rosario, Villanueva de Tapia, Villanueva del Trabuco. [Málaga] : Plan de Competitividad Turistica Sierra Norte de Málaga, D.L. 2009

INVENTARIO artístico de Málaga y su provincia. T.2: Partidos judiciales de Antequera, Marbella y Ronda. Madrid : Ministerio de Cultura, Centro Nacional de Información y Documentación del Patrimonio Histórico, $1985^{*}$

JIMÉNEZ GUERRERO, J. La Semana Santa de Málaga y provincia. En: La Semana Santa como patrimonio cultural de Andalucía. Artes y Artesanias de la Semana Santa Andaluza, no 1. Sevilla : Tartessos, 2006, p. 320-369 *

LÓPEZ BURGOS, M. A. Por tierras de Antequera : Relatos de viajeros ingleses durante el siglo XIX, Revista de estudios antequeranos, $n^{\circ} 12$, 2001, p. 331-390

LÓPEZ MARTÍNEZ, J.; DURÁN VALSERO, J. J. Torcal de Antequera, karst yesifero de Gobante, sierras del Valle de Abdalajis y desfiladeros de El Chorro. En : Elementos de los paisajes de la provincia de Málaga [actas de las XIII Jornadas de Campo de Geografía Física, abril 1997]. Málaga : Universidad de Málaga, 1999, p. $111-130$

MÁLAGA. Granada : Andalucia, D.L., 1994, 4 v. (Nuestra Andalucía) *

MENGA [Vídeo] : proceso de construcción. Sevilla : Consejería de Cultura, 2007 *

MERINO, Pedro F.; NIETO CRUZ, E. Ritos de pasión en la provincia de Málaga. [Málaga : Diario Málaga-Costa del Sol], D.L. 1997 
MINGORANCE GUTIÉRREZ, F. El Torcal de

Antequera. Natura, no 306, julio 2009, p. 8-21

MORALES, N. Archidona : paisajes y cultura : guía turistica de Archidona. Archidona : Ayuntamiento de Archidona, D.L. 2006

NAZARENOS de Málaga. Sevilla : Tartessos, $2007,6 v^{*}$

\section{NIELL CASTANERA, F. X.; LUCENA}

RODRÍGUEZ, J. Comentarios sobre un sistema único "La Laguna de Fuente de Piedra", ideas de cómo planificar su investigación y su uso. Oxyura : revista sobre las zonas húmedas, Vol.13, no 1, 1986, p. 35-42

NIETO CALDERA, J. M. [et al.]. Espacios de interés natural de la provincia de Málaga : I. Reserva integral de la Laguna de Fuente de Piedra, Jábega, n 57 (septiembre 1987), p. 76-80

PAJARES LADRERO, L. La comarca nororiental de Málaga :Archidona, Cuevas Bajas, Cuevas de San Marcos, Villanueva de Algaidas, Villanueva del Rosario, Villanueva de Tapia, Villanueva del Trabuco. Geografía, Historia y Cultura. Málaga : Nororma ; Centro de Ediciones de la Diputación de Málaga, D.L 2001

\section{PATRIMONIO cultural de Málaga y su}

provincia. Málaga : Málaga : Centro de Ediciones de la Diputación de Málaga, [19992002], 4 v. *

PERALTO, F. La iglesia rupestre de Villanueva de Algaidas y su sacro conjunto. Málaga : Corona del Sur, 2008, (Analecta malaginense histórica y legendaria ; 126)

PUERTAS TRICAS, R. Los conjuntos rupestres mozárabes de Coín y Archidona, Cuadernos de la Alhambra, n² 2, 1986, p.11-54 *

La REAL Colegiata de Antequera : cinco siglos de arte e historia (1503-2003). Antequera : Ayuntamiento de Antequera, Archivo Histórico Municipal, 2004 *

RUIZ GONZÁLEZ, Bartolomé. Dólmenes de Antequera : tutela y valorización hoy. Sevilla : Consejería de Cultura, 2009 (PH cuadernos ; 23) *
SAN MILLÁN Y GALLARÍN, Carlos. Semana

Santa en Antequera : crónica histórica : 19001950. Alhaurín de la Torre, Málaga: C. San

Millán, 2003

SEMANA Santa de Antequera 2009 : [N. especial dedicado a la Semana Santa]. Antequera : El Sol de Antequera, [2009]

SERRANO RAMOS, E.; ATENCIA PÁEZ, R. Notas sobre el teatro de "Singilia Barba". Cuadernos de arquitectura romana, n² 2, 1993, p. 207-215

SERRANO RAMOS, E.; ATENCIA PÁEZ, R. Un centro productor de "sigillata" hispánica en "Singilia Barba" (Antequera, Málaga). Baética : estudios de arte, geografia e historia, no 6, 1983 , p. $175-192$ *

TORRES, G. El Torcal de Antequera. Turismo rural, no 38,2000, p. 68-71

VENTURA MARTÍNEZ, J. J. Museo Municipal de Archidona (MuMa) (Archidona, Málaga) : la voluntad de un proyecto. Museo : revista de la Asociación Profesional de Museólogos de España, nº 6-7, 2001-2002, p. 107-131 *

Nota: Bibliografía seleccionada por Isabel Guzmán (Biblioteca del IAPH). Para una mayor información puede consultar el catálogo online de la Biblioteca del IAPH (http://www.juntadeandalucia.es/cultura/ iaph/absys/abwebp.exe)

Las publicaciones marcadas con asterisco (*) se encuentran disponibles para su consulta en la Biblioteca del IAPH. El resto de las referencias se han localizado en diversas fuentes de información (REBIUN, DIALNET, Base de datos de Bibliografia de patrimonio histórico, Catálogo de la Red de Bibliotecas públicas de Andalucía...) de ámbito nacional. 